\title{
Belgium: Detailed Assessment of Observance of Insurance Core Principles
}

This paper was prepared based on the information available at the time it was completed on May 16, 2013. The views expressed in this document are those of the staff team and do not necessarily reflect the views of the government of Belgium or the Executive Board of the IMF.

The policy of publication of staff reports and other documents by the IMF allows for the deletion of market-sensitive information.

Copies of this report are available to the public from

International Monetary Fund • Publication Services

700 19th Street, N.W. • Washington, D.C. 20431

Telephone: (202) 623-7430 • Telefax: (202) 623-7201

E-mail: publications@imf.org • Internet: http://www.imf.org

\section{International Monetary Fund Washington, D.C.}




\section{INTERNATIONAL MONETARY FUND}

\section{BELGIUM}

FINANCIAL SECTOR ASSESSMENT PROGRAM

May 16, 2013

\section{DETAILED ASSESSMENT OF OBSERVANCE}

INSURANCE CORE PRINCIPLES 


\section{Prepared By}

\section{Monetary and Capital Markets Department}

\section{CONTENTS}

Glossary

A. Information and Methodology Used for Assessment ___ 7

B. Overview_Institutional and Macro Prudential Setting ___ 8

C. Preconditions for Effective Insurance Supervision___ 18

D. Authorities' Response to the Assessment ___ 32

DETAILED PRINCIPLE-BY-PRINCIPLE ASSESSMENT _ 35

\section{FIGURES}

1: Net result of Belgian Insurers (company basis) 15

2: Twin Peaks Structure in Belgium 17

\section{TABLES}

1: Insurance Penetration and Density in 2011

2: Trend in Insurance Market Structure ___ 9

3: Insurance Distribution Channels__ 10

4: Analysis of Direct Insurers' Assets ___ 11

5: Assets Covering Technical Provisions___ 12

6: Analysis of Life Premiums __ 13

7: Major lines of General Insurance Business: Gross Premiums written ___ 14

8: Solvency Position of Insurers __ 15

9: Summary of Compliance with the ICPs__ 21

10: Summary of Observance Level ___ 28

11: Recommendations to Improve Observance of ICPs__ 28

12: Detailed Assessment of Observance of the ICPs ___ 35 


\section{Glossary}

\begin{tabular}{|c|c|}
\hline ALM & Asset-liability management \\
\hline Board & Board of Directors \\
\hline CBFA & Commission Bancaire, Financière et des Assurances \\
\hline CTIF & Financial Intelligence Unit \\
\hline CGC & The NBB's Corporate Governance Charter \\
\hline Cir-CG & Internal Governance Circular \\
\hline $\mathrm{CoB}$ & Conduct-of-business \\
\hline Control Office & $\begin{array}{l}\text { Control Office of mutual health funds and national unions } \\
\text { of mutual health funds }\end{array}$ \\
\hline Council & Council of Regency \\
\hline CSRSFI & $\begin{array}{l}\text { Committee for Systemic Risks and System-relevant } \\
\text { Financial Institutions }\end{array}$ \\
\hline EBA & European Banking Authority \\
\hline $\mathrm{ECB}$ & European Central Bank \\
\hline EEA & European Economic Area \\
\hline EIOPA & European Insurance and Occupational Pensions Authority \\
\hline ESAs & European Supervisory Authorities \\
\hline ESCB & European System of Central Banks \\
\hline ESFS & European System of Financial Supervisors \\
\hline ESRB & European Systemic Risk Board \\
\hline EU & European Union \\
\hline FSAP & Financial Sector Assessment Program \\
\hline FSMA & Financial Services and Markets Authority \\
\hline FTE & Full-time-equivalent \\
\hline IAIS & International Association of Insurance Supervisors \\
\hline ICPs & Insurance Core Principles \\
\hline IFRS & International Financial Reporting Standards \\
\hline ILPs & Investment-linked policies \\
\hline Insurance Law (IL) & $\begin{array}{l}\text { The Law of } 9 \text { July } 1975 \text { on the supervision of insurance } \\
\text { undertakings }\end{array}$ \\
\hline Intermediation Law & $\begin{array}{l}\text { The Law of } 27 \text { March } 1995 \text { on insurance and reinsurance } \\
\text { intermediation and the distribution of insurance }\end{array}$ \\
\hline $\mathrm{MHF}$ & Mutual health funds \\
\hline MCR & Minimum capital requirement \\
\hline MiFID & Markets In Financial Instruments Directive \\
\hline Minister & Minister of Finance \\
\hline MoF & Ministry of Finance \\
\hline MoU & Memorandum of Understanding \\
\hline MoU-FS & $\begin{array}{l}\text { MoU on cooperation on cross-border financial stability } \\
\text { between the supervisory authorities, central banks and } \\
\text { finance ministries of the EU }\end{array}$ \\
\hline
\end{tabular}


NBB

NBB Statutes

NBB Organic Law

ORSA

PCR

RD-AA

RD-CA

RD-IL

RD-LA

Reinsurance Law (RL)

SCR

SIFIs

Supervision Law (SL)

Twin-Peak Decree

(RD-TP)

TIP Law

TP

TP\&CP Law

UCITs
National Bank of Belgium

The Law of 22 February 1998 on the Organic Statute of the National Bank of Belgium

Organic Statute of the National Bank of Belgium adopted by the General Council on 23 December 1998

Own-Risk and Solvency Assessment

Prescribed capital requirement

Royal Decree of 17 November 1994 on the annual accounts of insurance undertakings.

Royal Decree of 27 September 2009 on the consolidated accounts of insurance and reinsurance undertakings

Royal Decree of 22 February 1991

Royal Decree of 14 November 2003 on Life Assurance;

The Law of 16 February 2009 on reinsurance companies

Solvency Capital Requirement

Systemically important financial institutions

The Law of 2 August 2002 on the supervision of the financial sector and on financial services

Royal Decree implementing the development of financial supervisory structures of 3 March 2011

Law of 25 June 1992 on terrestrial insurance policies.

Technical provisions

The Law of 6 April 2010 on trade practices and consumer protection

Undertakings for Collective Investment in Transferable

Securities 


\section{EXECUTIVE SUMMARY}

1. The Belgian insurance industry is mature and concentrated. It is relatively small compared to the banking sector: assets held by banks ( $€ 1,185$ billion) are five times of those held by insurers ( $€ 250$ billion) as at September 2011. Although there are 92 direct insurers, the industry is dominated by the 23 composite insurers that conduct both life and non-life insurance operations, accounting for more than 90 percent of total industry assets. In 2011, the top five life insurers accounted for 71 percent of the assets while the top five non-life insurers held 58 percent of the assets. The top three insurance groups held more than 60 percent of the total assets as at end-2011.

\section{Belgian insurers were adversely affected by the global financial crisis and continue to} confront challenges related to legacy assets and economic uncertainties in Europe.

Government support was extended to a few insurers to maintain the stability of the industry in 2008. Nevertheless, the insurance industry's solvency position has continued to weaken since 2009, and life insurers have significant exposures to guaranteed high returns in part of their legacy portfolios. Insurers hold high levels of government bonds ( $€ 104$ billion), accounting for 41 percent of assets at end-2011, of which $€ 59.6$ billion were in Belgian government bonds. Investments in corporate bonds represent 23 percent ( $€ 59.6$ billion) of total assets. The solvency margins computed under the current Solvency I regime tend to under-estimate risks. While insurers have been gradually shifting toward contracts that offer lower guarantees, some of the new contracts offer more policy options, increasing the risks of surrenders by policyholders. The demand for life policies has been eroded by households' stronger preference for liquidity in recent years. Non-life insurers have taken measures to improve their underwriting performance although they remain susceptible to investment risks.

3. The Belgian authorities have made significant progress in updating the insurance regulatory regime and supervisory practice since 2004. As a member of the European Union (EU), the Belgian regulatory regime is largely shaped by EU Directives on licensing, solvency, insurance intermediaries and consumer protection. The authorities have implemented the Flashing Light Provisions to strengthen the solvency requirements of life insurers with exposures to legacy portfolios and enhanced the risk management requirements for insurers. The supervisory architecture has been overhauled with the implementation of the Twin Peaks structure in April 2011. The National Bank of Belgium (NBB) is in charge of the micro- and macro-prudential supervision of insurers, while the Financial Services and Markets Authority (FSMA) is responsible for registering the intermediaries and for supervising the conduct of business by insurers and intermediaries. The NBB has introduced a supervisory framework that integrates vertical analyses of individual insurers with horizontal review of the insurance sector, while leveraging on the macroeconomic competencies of the NBB. Checks-and-balances in the supervisory process have been enhanced through the separation of vertical and horizontal supervision as well as offsite review and onsite inspections.

4. There is scope for strengthening the supervisory structure and the legal capacity of the NBB. The Twin Peaks structure establishes clear supervisory mandates and enhances checks-andbalances. A key success factor is effective communication and coordination. A regular review of the 
practical implementation of the Twin Peaks to identify and assess potential gaps, duplication or coordination issues are needed to ensure that the overall supervisory objectives for the insurance sector are effectively achieved. A more principles-based approach in delegating legal authority to the NBB to issue enforceable rules is needed to facilitate supervisory discretion within the parameters set by the law. The NBB should be empowered to take immediate recovery measures not withstanding an appeal by an insurer. As an integrated prudential supervisor, there are merits in articulating clear policies to deal with potential conflicts in supervisory objectives, e.g., between financial stability and prudential safeguards for policyholders. To avoid possible doubts, the authorities should consider clarifying in the legal framework that the Minister of Finance's (the Minister's) scope of supervision of the NBB's transactions does not cover supervisory activities.

5. The updated regulatory framework has a high level of observance with the Insurance Core Principles (ICPs), supported by robust prudential supervision. The majority of the downgrades in ratings reflect gaps in the regulatory framework, i.e.; scope of the fit and proper requirements; duties of directors particularly with respect to policyholders; public disclosures; updating the prudential standards for asset-liability management and realistic contingency plans for going- and gone-concern situations. The NBB's decision to enhance the current solvency regime ahead of the implementation of Solvency II is a welcome initiative, and should contribute to the longer-term sustainability of insurers. Further improvements in the NBB's risk-based supervision could be achieved through: a) the formulation of an appropriate baseline supervisory program; $b$ ) internal policies for inspecting functions outsourced by insurers; and c) review of the effectiveness of contributions of external auditors and the role of actuaries.

\section{The authorities are advised to review current conduct-of-business (CoB) regulation and supervision to strengthen the protection for policyholders. Although training and} qualification requirements imposed by the FSMA complies with the IMD directive at the European level, there is scope to enhance the level of professionalism of intermediaries through more robust training requirements and appropriate supervisory measures to deter unhealthy competition arising from more than 17,000 intermediaries. The FSMA proposes to adapt the Markets in Financial Instruments Directive 2 (MiFID 2) to insurers and insurance intermediaries, aimed at providing a cross-sectoral and comprehensive framework for CoB regulation. The FSMA should be empowered via regulations to establish enforceable rules on: a) handling of claims and proper policy servicing by insurers; b) market conduct requirements at the group level; and c) combating and reporting insurance fraud by intermediaries.

\section{It will be important that the NBB and the FSMA are adequately resourced to} effectively discharge their supervisory mandates. The NBB is advised to regularly review its resource planning to achieve the appropriate supervisory intensity and effectiveness and an appropriate baseline program. Going forward, there are also significant resource implications arising from the implementation of Solvency II and supervision of complex cross-border insurance groups/conglomerates. The FSMA needs to strategize an appropriate risk-based supervisory approach to deal with the large population of regulated entities and ensure adequate resources to implement the strategy. 


\section{ASSESSMENT OF INSURANCE CORE PRINCIPLES INTRODUCTION AND SCOPE}

8. This assessment provides an update on the significant regulatory and supervisory developments in the insurance sector of Belgium since 2006. The assessment was conducted by Su Hoong Chang (Senior Financial Sector Expert, IMF) and Philipp Keller (external expert engaged by the IMF) from November 6 to 20, 2012. Belgium undertook an initial Financial Sector Assessment Program (FSAP) in 2006, which included a formal assessment of its observance with the Insurance Core Principles (ICPs) issued by the International Association of Insurance Supervisors (IAIS) in 2003.

9. The current assessment is benchmarked against the ICPs issued by the IAIS in October 2011. The ICPs apply to all insurers, whether private or government-controlled. Specific principles apply to the supervision of intermediaries. With the implementation of the twin peaks supervisory structure in Belgium on 1 April 2011 (outlined in paragraph 27), the assessment covers the supervisory practices of both the NBB and FSMA.

\section{A. Information and Methodology Used for Assessment}

10. The level of observance for each ICP reflects the assessments of the corresponding standards. Each ICP is rated in terms of the level of observance as follows:

a) Observed: where all the standards are observed except for those that are considered not applicable. For a standard to be considered observed, the supervisor must have the legal authority to perform its tasks and that it exercises this authority to a satisfactory level.

b) Largely observed: where only minor shortcomings exist, which do not raise any concerns about the authorities' ability to achieve full observance.

c) Partly observed: where, despite progress, the shortcomings are sufficient to raise doubts about the authorities' ability to achieve observance.

d) Not observed: where no substantive progress toward observance has been achieved.

11. The assessment is based solely on the laws, regulations and other supervisory requirements and practices that are in place at the time of the assessment. Ongoing regulatory initiatives are noted by way of additional comments. A comprehensive self-assessment and other pertinent information (supervisory reports and analysis, studies, consultation papers, etc.) provided by the authorities facilitated a meaningful assessment. Technical discussions with and briefings by officials from the NBB and FSMA have enriched the analysis in this report.

\section{The assessors are grateful to the authorities for the full cooperation and thoughtful} logistical arrangements, particularly the helpful co-coordination of various meetings with industry participants. The assessors benefited from the valuable inputs and insightful views from meetings with insurers, industry and professional organizations. 


\section{B. Overview-Institutional and Macro Prudential Setting}

\section{Market structure and industry performance}

\section{Industry structure and recent trends}

\section{The insurance industry in Belgium is relatively small compared to the banking sector} and its penetration and density rates are comparable to other advance markets (Table 1 ).

Assets held by banks ( $€ 1,185$ billion) are five times of the total assets of the insurance industry ( $€ 250$ billion) as at September 2011. Higher penetration and density rates are recorded for life insurance compared to non-life insurance. The insurance density in Belgium is lower than the average recorded in advanced markets, largely due to significant level of coverage by the social security system. In 2009, 46,797 individuals worked in the insurance industry.

Table 1: Insurance Penetration and Density in 2011

\begin{tabular}{|l|c|c|}
\hline & $\begin{array}{c}\text { Insurance Penetration } \\
\text { (As \% of GDP) }\end{array}$ & $\begin{array}{c}\text { Insurance density } \\
\text { (US\$ per capita) }\end{array}$ \\
\hline Non-life & 3.2 & 1,079 \\
Belgium & 3.6 & 1,543 \\
Advanced markets & & \\
\hline Life & 5.2 & 1,756 \\
Belgium & 5.0 & 2,168 \\
Advanced markets & & \\
\hline
\end{tabular}

Source: World Insurance in 2011, Swiss Re (data on advanced markets)

The NBB (data on Belgium)

\section{The total number of insurers has been decreasing steadily since $\mathbf{2 0 0 8}$ with no change} in the number of insurance groups (Table 2). More than one third of the insurers operate as branches in Belgium, and all the branches are headquartered in the European Economic Area (EEA). While the number of non-life insurers was the highest, composite insurers dominate in terms of scale of operations (Table 3). Composite insurers that conduct both life and non-life operations are prohibited, except for those that were grandfathered at the time the legal prohibition was introduced in 1992. The number of composite insurers has increased from 21 to 23 because two life insurers were reclassified as composite insurers since 2010/2011 after having been authorized to undertake health insurance business. The operations of the Belgian reinsurers are insignificant. There is no restriction on entry and foreign ownership. Ownership of insurers is split evenly between domestic and foreign stakeholders. 
Table 2: Trend in Insurance Market Structure

\begin{tabular}{|c|c|c|c|c|c|}
\hline & 2008 & 2009 & 2010 & 2011 & Jun 2012 \\
\hline Life & 22 & 21 & 20 & 18 & 17 \\
\hline Non-life & 57 & 54 & 53 & 52 & 52 \\
\hline Composite & 21 & 21 & 22 & 23 & 23 \\
\hline \multirow[t]{2}{*}{ Reinsurance } & & 1 & 2 & 2 & 2 \\
\hline & 100 & 97 & 97 & 95 & 94 \\
\hline \multicolumn{6}{|l|}{ Supplementary information } \\
\hline Foreign branches & 52 & 51 & 50 & 54 & 54 \\
\hline Local insurers' branches abroad & 51 & 39 & 44 & 41 & 50 \\
\hline Insurance groups & 9 & 9 & 9 & 9 & 9 \\
\hline
\end{tabular}

Source: National Bank of Belgium.

\section{The Belgian insurance industry is dominated by a few financial conglomerates and is} concentrated. The top three insurance groups held more than 60 percent of the total industry assets as at end-2011. The top five life insurers accounted for 71 percent of the assets while the top five non-life insurers held 58 percent of non-life premiums in 2011. The nine insurance groups derived, on average, more than 90 percent of their premiums from domestic operations, in 2011. Only one (and the largest) insurance group wrote about 34 percent of its premiums from outside Belgium.

\section{Insurance policies are distributed mainly through brokers and bancassurance (Table 3 ).} Bancassurance continues to dominate life insurance sales, particularly in investment-linked policies (ILPs) and mortgage insurance. Direct sales are mainly done through mutuals and cooperatives and corporate accounts. As at end-2011, there were 17,285 insurance intermediaries comprising 3,587 agents; 5,408 sub-agents; and 8,290 brokers. The number of intermediaries has declined significantly from the 26,307 in 2005, when the regulation of insurance intermediaries was implemented in EU. Further consolidation of intermediaries is expected as the FSMA plans to strengthen conduct-ofbusiness regulation and supervision (please refer to ICP 18 and 19). 
Table 3: Insurance Distribution Channels

\begin{tabular}{|l|rrr|}
\multicolumn{1}{c}{ (percent) } \\
\hline & $\mathbf{2 0 0 8}$ & $\mathbf{2 0 0 9}$ & $\mathbf{2 0 1 0}$ \\
\hline Brokers $^{\text {Assurfinance }}{ }^{1}$ & 34.6 & 34.9 & 34.5 \\
Exclusive agents $^{2}$ & 8.5 & 8.3 & 8.3 \\
Bancassurance $^{2}$ & 6.3 & 6.8 & 6.8 \\
Direct sales & 30.2 & 29.7 & 30.5 \\
Others & 17.5 & 17.7 & 17.2 \\
\hline & 2.9 & 2.6 & 2.7 \\
\hline
\end{tabular}

Source: National Bank of Belgium

\section{Assets and liabilities}

17. Composite insurers accounted for more than $\mathbf{9 0}$ percent of the industry's total assets and they held the highest level of government and corporate securities totaling $\mathbf{€ 1 5 2 . 9}$ billion (Table 4). Life insurers have the smallest asset base although with similar concentration in fixed income securities. Investments supporting investment-linked policies (ILPs) represented only 7 percent of total industry assets. Notably, non-life insurers have a relatively higher level of receivables and reinsurance recoverables, the latter was largely due to the higher level of reinsurance for nonlife business, which is typical.

\section{Insurers' holdings of government bond totaled $€ 103.9$ billion as at end-2011, of which} about $€ \mathbf{5 9 . 6}$ billion $^{3}$ were invested in Belgian government bonds. Insurers increased their holdings of Belgian government bonds by 55 percent relative to end-2010, drawn by the attractive yields on Belgian government bonds, which peaked in December 2011. Sovereign bonds issued by France ( $€ 21.6$ billion at book value) and Germany ( $€ 8.5$ billion) also represented a significant share of the government bond portfolio. Exposures to other euro area countries fell to $€ 14$.4 billion, as insurers had reduced their exposure to these countries by more than $€ 5$ billion in 2010 and by a further $€ 7$ billion in $2011{ }^{4}$

\footnotetext{
${ }^{1}$ Assurfinance: distribution by independent banking agents who work for a financial group and registered with the FSMA to sell insurance products of other financial groups.

${ }^{2}$ Bancassurance: distribution by bank employees who sell products of the same financial group.

${ }^{3}$ Based on book value, which is lower than the market value of $€ 61.4$ billion.

${ }^{4}$ These exposures are gross positions at book value, without adjustment for any associated hedging.
} 
Table 4: Analysis of Direct Insurers' Assets

(in $€$ million, unless stated otherwise)

\begin{tabular}{|l|rr|rr|rr|rr|}
\hline & \multicolumn{1}{l|}{ Life } & & \multicolumn{1}{l|}{ Non-Life } & & Composite & \multicolumn{2}{l|}{ Total } & \\
\hline Government & & & & & & & & \\
securities & 2,894 & $30 \%$ & 3,338 & $29 \%$ & 97,659 & $42 \%$ & $\mathbf{1 0 3 , 8 9 1}$ & $41 \%$ \\
Corporate & & & & & & & & \\
securities & 2,369 & $25 \%$ & 2,019 & $17 \%$ & 55,235 & $24 \%$ & $\mathbf{5 9 , 6 2 3}$ & $23 \%$ \\
Equities & 462 & $5 \%$ & 874 & $7 \%$ & 9,303 & $4 \%$ & $\mathbf{1 0 , 6 4 0}$ & $4 \%$ \\
Real estate & 253 & $3 \%$ & 148 & $1 \%$ & 3,417 & $1 \%$ & $\mathbf{3 , 8 1 8}$ & $1 \%$ \\
Cash \& deposits & 440 & $5 \%$ & 588 & $5 \%$ & 6,215 & $3 \%$ & $\mathbf{7 , 2 4 4}$ & $3 \%$ \\
ILP Investments & 741 & $8 \%$ & & $0 \%$ & 17,821 & $8 \%$ & $\mathbf{1 8 , 5 6 2}$ & $7 \%$ \\
Receivables & 152 & $2 \%$ & 1,234 & $11 \%$ & 5,518 & $2 \%$ & $\mathbf{6 , 9 0 3}$ & $3 \%$ \\
R/I recoverable & 194 & $2 \%$ & 2,183 & $19 \%$ & 4,734 & $2 \%$ & $\mathbf{7 , 1 1 1}$ & $3 \%$ \\
Total assets & $\mathbf{9 , 5 2 9}$ & $100 \%$ & $\mathbf{1 1 , 6 5 7}$ & $100 \%$ & $\mathbf{2 3 4 , 0 5 5}$ & $100 \%$ & $\mathbf{2 5 5 , 2 4 3}$ & $100 \%$ \\
\% of Industry Total & $3.7 \%$ & & $4.6 \%$ & & $91.7 \%$ & & $100.0 \%$ & \\
\hline
\end{tabular}

Source: National Bank of Belgium.

\section{For assessing the solvency of insurers at the solo level, all financial instruments are} valued at amortized cost, to be consistent with the valuation approach for technical

provisions (TP). Subject to the approval of the NBB, the net unrealized valuation gains may be used to meet the regulatory solvency margin requirement. For the assets covering TP, the valuation approach is market-based, except for government bonds which are valued at amortized cost less depreciation. As at end-2011, insurers' holdings of Belgian government bonds recorded a higher market value than the book value. 
Table 5: Assets Covering Technical Provisions

(in € million)

\begin{tabular}{|l|rr|r|rr|r|}
\hline & & & \multicolumn{3}{|c|}{ Composite } & Industry \\
\cline { 5 - 6 } & Life & Non-Life & \multicolumn{1}{c|}{ Life } & Non-Life & Total & Total \\
\hline As at end-2011 & & & & & & \\
Covering Assets & 8,430 & 8,790 & 183,984 & 24,301 & 208,285 & 225,505 \\
Technical provisions (TP) & 8,418 & 7,142 & 179,306 & 22,348 & 201,654 & 217,214 \\
Total liabilities & 9,529 & 11,657 & & & 234,055 & \\
TP as \% of liabilities & $88 \%$ & $61 \%$ & & & $86 \%$ & \\
Trend of TP & & & & & & \\
\hline 2007 & 31,976 & 9,556 & 124,230 & 18,018 & 142,248 & 183,780 \\
2008 & 14,553 & 7,553 & 142,820 & 21,151 & 163,971 & 186,077 \\
2009 & 14,843 & 5,975 & 155,218 & 21,523 & 176,741 & 197,559 \\
2010 & 7,983 & 6,247 & 173,844 & 22,040 & 195,884 & 210,114 \\
2011 & 8,418 & 7,142 & 179,306 & 22,348 & 201,654 & 217,214 \\
$\%$ change 2007 to 2011 & $-73.7 \%$ & $-25.3 \%$ & $44.3 \%$ & $24.0 \%$ & $41.8 \%$ & $18.2 \%$ \\
\hline
\end{tabular}

Source: National Bank of Belgium.

20. While composite insurers have increased their TP since 2007, TP maintained by the other direct insurers have declined (Table 5). Assets covering TP are subject to stringent regulatory requirements in order to safeguard the interests of policyholders (please see details under ICP 15). In this regard, any liquidity swap between an insurer and a related bank involving assets covering TP needs to be notified to the NBB in order to check compliance with the concentration limits.

\section{Underwriting performance}

\section{Life insurance premiums have declined since 2007 mainly due to the ongoing}

economic uncertainties (Table 6). In recent years, households' stronger preference for liquidity has eroded demand for life insurance products. This is compounded by the predominance of the bancassurance business model in Belgium, which might have motivated some banks needing substantial liquidity to channel household savings into banking products at the point of sale. About 85 percent of the premiums relate to traditional policies while ILPs, under which investment risks are assumed by the policyholders, accounted for an average of 15 percent of total premiums for the period 2007-2011. 
Table 6: Analysis of Life Premiums

(in $€$ billion)

\begin{tabular}{|l|rrrr|rr|}
\hline & $\mathbf{2 0 0 7}$ & $\mathbf{2 0 0 8}$ & $\mathbf{2 0 0 9}$ & $\mathbf{2 0 1 0}$ & $\mathbf{2 0 1 1}$ & \\
\hline Traditional & & & & & & \\
$\quad$ Individual & 13.7 & 12.5 & 11.7 & 12.1 & 11.5 & $61 \%$ \\
$\quad$ Group & 4.2 & 4.4 & 4.6 & 4.6 & 4.6 & $25 \%$ \\
Investment- & & & & & & \\
linked & 3.1 & 3.1 & 1.4 & 1.9 & 2.0 & $11 \%$ \\
Others & 1.2 & 1.2 & 1.2 & 0.6 & 0.6 & $3 \%$ \\
\hline Total & $\mathbf{2 2 . 2}$ & $\mathbf{2 1 . 2}$ & $\mathbf{1 8 . 9}$ & $\mathbf{1 9 . 2}$ & $\mathbf{1 8 . 7}$ & $100 \%$ \\
\hline \% Change & & $-4.5 \%$ & $-10.8 \%$ & $1.6 \%$ & $-2.6 \%$ & \\
\hline
\end{tabular}

Source: National Bank of Belgium.

22. The bulk of the traditional life policies offer guaranteed rates of returns; and it is difficult for life insurers to meet the guarantees made in their legacy portfolios. In the $1990 \mathrm{~s}$, insurers tended to offer guaranteed returns of up to 4.75 percent, the statutory ceiling up to 1999, which was then reduced to 3.75 percent. The pressure to retain high maximum returns is particularly strong for group life insurance where an employer has a legal obligation to ensure a minimum return of 3.25 percent on employers' contributions and 3.75 percent on employees' contributions. Around 52 percent of Belgian employers participate in supplementary pensions contracts, which accounted for about 25 percent of life premiums ( $€ 4.6$ billion) in Belgium in $2011 .{ }^{5}$ For competition reasons, insurers have tended to offer the same minimum returns for group insurance contracts.

\section{Insurers have been gradually shifting toward contracts that offer lower guaranteed} yields but remain exposed to the options available to policyholders. The guaranteed rates for new polices correspond to the market risk-free interest rate prevailing at the time of premium payments. Moreover, some contracts specify that the guarantee is limited in time, i.e., at the end of the period the contract reserve is regarded as new premiums subject to the interest rate prevailing at that time. As a result, the guaranteed average return on traditional policies declined from 4.5 percent as at end-1999 to 3.2 percent as at end-2010. The actual returns on the investments covering traditional contracts were around 4.5 percent in 2009 and 3.8 percent in 2010. The NBB requires insurers to establish additional provision for contracts offering a guaranteed return above the "flashing light rate" ${ }^{\prime 6}$ and allocate reserves to this provision over a maximum of ten years (elaborated in ICP 14). However, some new contracts offer more flexibility to policyholders which may expose insurers to a greater risk of policy surrenders and hence higher liquidly risks.

\footnotetext{
${ }^{5}$ Source: Moody's_-Belgian Ministry of Economy rejects the National Bank's decision to lower the maximum guaranteed rate on long-term life insurance contract, a credit negative for insurers," November 1, 2012.

${ }^{6}$ Defined as 80 percent of the average yield on 10-year government bonds on the secondary market over the past five years. The flashing light rate is calculated annually by the NBB and was 3.26 percent as at end-2011.
} 
24. Non-life insurers have taken measures to improve their underwriting performance. Gross written premiums rose marginally to reach $€ 10.3$ billion in 2011 (Table 7). Motor insurance is the dominant class, with 33 percent share of gross premium written, followed by accident and health (24 percent). In response to the renewed increase in the combined ratio ${ }^{7}$ in 2009 and 2010, non-life insurers increased the level of premiums, improved cost control and imposed stricter underwriting terms for certain loss-making insurance products and classes. The combined ratio dipped to 99.8 percent in 2011, the first time that the ratio fell below 100 percent since 2004.

Table 7: Major lines of General Insurance Business: Gross Premiums written (in € million)

\begin{tabular}{|l|rrr|}
\hline & $\mathbf{2 0 0 9}$ & $\mathbf{2 0 1 0}$ & \multicolumn{1}{c|}{$\mathbf{2 0 1 1}$} \\
\hline Motor & 3,140 & 3,255 & 3,406 \\
Property & 2,136 & 2,181 & 2,334 \\
Liabilities & 686 & 688 & 700 \\
Accident \& health & 2,385 & 2,443 & 2,505 \\
Others & 1,238 & 1,308 & 1,366 \\
\cline { 2 - 4 } & 9,584 & 9,875 & 10,310 \\
\hline
\end{tabular}

Source: National Bank of Belgium.

\section{Profitability and solvency}

25. The global financial crisis in $\mathbf{2 0 0 8}$ resulted in the need to provide government support to a few systemically important institutions. The Dexia Group was particularly hard hit due to its large exposures to sovereign risks and heavy dependence on wholesale funding. Dexia Bank Belgium, together with its insurance arm, was acquired by the Belgian State for $€ 4$ billion. ${ }^{8}$ Other Belgian insurers that received state support were Ethias and $\mathrm{KBC}$ Insurance.

\section{Depressed financial markets continue to adversely affect insurers' investment}

performance in 2011. In response, insurers have trimmed down their bond investments resulting in a realized loss totaling $€ 4.1$ billion on Greek government bonds and other European peripheral government bonds recorded by life insurers. Non-life insurers also suffered a decline in investment income from $€ 1.2$ billion in 2010 to $€ 0.9$ billion in 2011. Unrealized investment gains totaled $€ 3.8$ billion (sovereign bonds accounted for $€ 1.4$ billion) as at end-2011.

\section{Profitability trend has been volatile since $\mathbf{2 0 0 7}$ and the industry reported a net loss of} €0.9 billion in 2011 (Chart 1), compared a net profit of $€ 1.4$ billion in 2010. The technical result of Belgian life insurance activity traditionally combines a negative result on insurance activities counterbalanced by a positive investment result. In 2011, the net investment income of life insurers

\footnotetext{
${ }^{7}$ Total cost of claims plus operating expenses to net premium income.

${ }^{8}$ The Group has rebranded in early 2012 under a new commercial name Belfius.
} 
fell to $€ 4.0$ billion (2010: $€ 7.8$ billion), which partly offset the underwriting loss of $€ 4.7$ billion, ending with an overall operating loss of $€ 0.7$ billion. Non-life insurance activity reported net operating income of $€ 1.8$ billion while a net loss of $€ 1.1$ billion was recorded in insurers' non-technical accounts.

Figure 1: Net result of Belgian Insurers (company basis)

(in € billion)

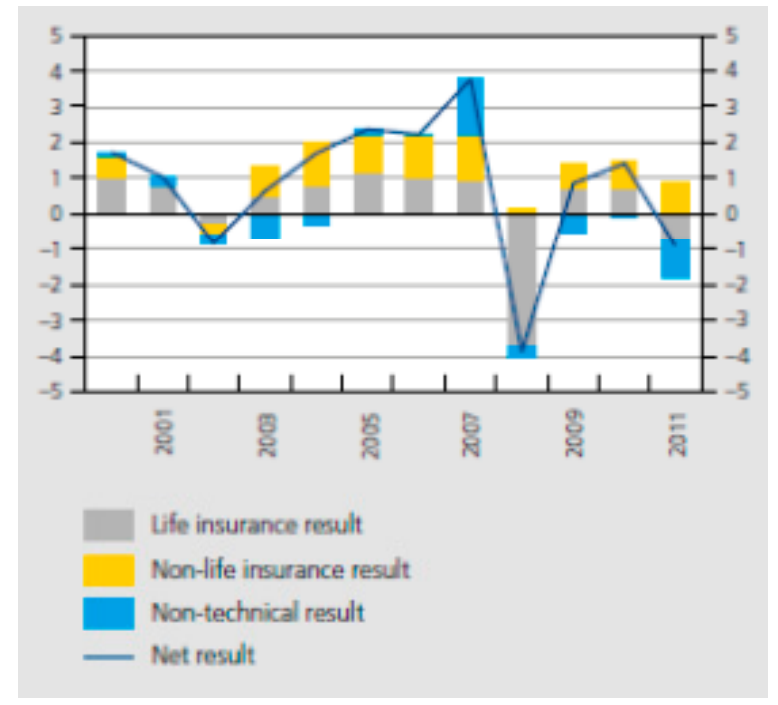

Source: National Bank of Belgium

28. Overall, the insurance industry solvency position has weakened since 2009, although the capital requirements under Solvency I were met. (Table 8).

Table 8: Solvency Position of Insurers

(in percent)

\begin{tabular}{|c|c|c|c|}
\hline Solvency margin(Solvency I) & 2009 & 2010 & 2011 \\
\hline Life (long-term) & 208 & 192 & 169 \\
\hline Non-life (general) & 311 & 299 & 284 \\
\hline Reinsurance & 0 & 187 & 171 \\
\hline
\end{tabular}

Source: National Bank of Belgium.

29. The adjusted average solvency margins of the insurance sector tend to be over-stated. The current Solvency I framework does not value technical provisions in a market consistent basis nor does it take account of the impact of movements in interest rate. The regulatory solvency margin consists of: a) an explicit margin which includes own funds, subordinated debts and other qualified balance sheet items; and b) an implicit margin which comprises the net unrealized gains on investments, as approved by the NBB. Such unrealized gains fluctuate in line with the fluid market conditions, as evidenced in the last two years. The implicit margin is, therefore, not a stable source 
of solvency support as it could dissipate during a market downturn when insurers' need for additional financial resources is critical.

\section{Since 2009, the authorities and the industry haven been preparing for the} implementation of Solvency II. The adoption of Solvency II is expected to facilitate risk-based supervision and provide regulatory incentives for insurers to properly measure and manage all relevant key risks. Solvency requirements are to be based on a market consistent valuation of an insurer's assets and liabilities (including TP) based on a total balance sheet approach. The Solvency Capital Requirement (SCR) requires insurers to hold regulatory capital at a level that would ensure that it would meet its obligations to policyholders and beneficiaries with a probability of at least 99.5 percent, over a one-year horizon. The strongest supervisory measures would be taken against insurers who fail to meet the Minimum Capital Requirement (MCR). Insurers are also required to establish, as an integrated part of their capital management strategy, policies and processes to assess their overall solvency needs tailored to their specific risk profile i.e., Own-Risk and Solvency Assessment (ORSA). More details are outlined in ICP 17.

\section{The NBB has decided to move forward with the implementation of the requirements} under Solvency II, ahead of the official implementation by the EU. Current indications are that Solvency II may not come into effect before 2016. The mission welcomes the NBB's proactive approach, which will support effective risk-based supervision by the NBB. The enhanced regime should aim at improving the long-term sustainability and resilience of insurers, with due consideration for the market structure and risk profile in Belgium.

\section{Risks and vulnerabilities}

\section{High exposure to guaranteed rate contracts and declining long-term interest rates} remain the key risks for life insurers, compounded by the current depressed financial markets.

Despite positive measures by life insurers to limit such guarantees for new policies, their legacy portfolios still represent a substantial amount of liabilities. Technical provision associated with guaranteed rates of return of 4.75, 4.5, 3.75 and 3.5 percent for traditional individual policies totaling $€ 32$ billion as at end-2010 or 31.5 percent of the total TP for this class of business. The NBB's prudential decision to lower the maximum interest rate from 3.75 percent to 2 percent was vetoed by the Ministry of Economy and Consumer Affairs. ${ }^{9}$ The grounds for rejection are that a lower maximum rate is harmful to competition; the NBB is already empowered to intervene on a case-bycase basis if it opines an insurer offers a guarantee rate imprudently; and the average return on pension contributions over the past 20 years was 6 percent. The key prudential risk following this decision is that insurers continue to offer the same maximum guarantee rate for competitive reasons (as evidenced in the past), despite significant uncertainties as to whether they are able to generate investment returns of 3.75 percent, over the next 10 to 20 years.

\footnotetext{
${ }^{9}$ Article 19 of the Insurance Law states that the Minister may "....on his own initiative or at the request of the Council of Ministers, exercise a right of call-back within 15 days subject to the submission of detailed grounds."
} 
33. Non-life insurers are exposed to increasing frequency and severity of catastrophic events and similar market risks on their investment portfolios. As in the case of life insurers, non-life insurers also have significant holdings in sovereign and corporate bonds, which could be amplified by further deterioration in economic conditions in the region. While the peak losses over the last 10 years had not caused any financial problem, the NBB monitors the adequacy and security of non-life insurers' reinsurance program, including the aging analysis of reinsurance recoverables.

\section{Institutional framework and arrangements}

34. Belgium implemented the twin peaks supervisory structure on 1 April 2011. The NBB is in charge of the micro- and macro-prudential supervision of credit institutions, stockbroking firms, insurers and settlement institutions as well as monitors the stability of the Belgian financial system. The FSMA is responsible for the supervision of financial markets and consumer protection, for the supervision of Undertakings for Collective Investment in Transferable Securities (UCITs), for registering UCI management companies, portfolio management companies, mortgage companies, and financial intermediaries (including insurance intermediaries), and for supervising the conduct of business all financial institutions. ${ }^{10}$ In addition, the FSMA is responsible for the prudential supervision of pension funds. The NBB and the FSMA also supervise financial entities pursuant to the anti-money laundering law/ regulations, in their respective areas of competencies.

Figure 2: Twin Peaks Structure in Belgium

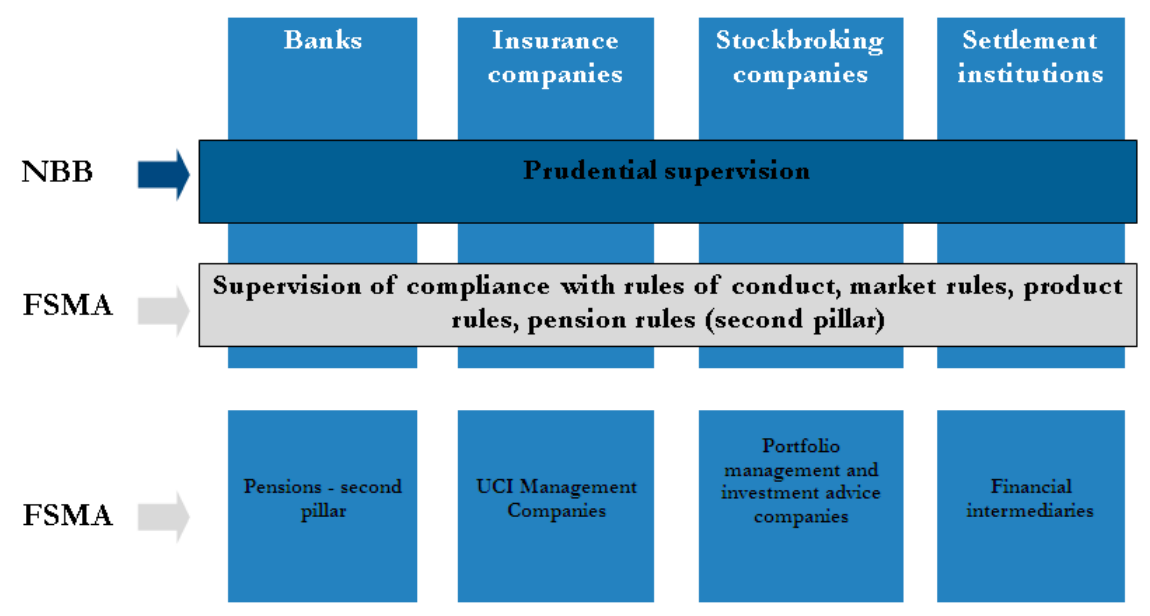

Source: Financial Services and Markets Authority.

35. The new institutional architecture dovetails with the establishment of the European System of Financial Supervisors (ESFS) on January 1, 2011. The ESFS comprises the European Systemic Risk Board (ESRB), responsible for macroprudential oversight, and three European Supervisory Authorities (ESAs) charged with microprudential supervision of the banking, insurance and securities markets in Europe, namely the European Banking Authority (EBA), the

\footnotetext{
${ }^{10}$ Previously, the CBFA was the integrated supervisor for the Belgian financial sector.
} 
European Insurance and Occupational Pensions Authority (EIOPA) and the European Securities and Markets Authority (ESMA). The ESFS aims to ensure better systemic risk prevention and promotes the harmonization of prudential rules and practices at European level, while reinforcing cooperation between national authorities.

\section{The NBB does not supervise mutual health funds (MHF), which are non-profit} organizations that operate the national compulsory health insurance system, based on the principle of solidarity and mutual assistance between members. These mutual health funds also have a relatively small insurance activity aside from their major activity in the Belgian social security system. MHF are under the purview of the Control Office of mutual health funds and national unions of mutual health funds (Control Office), established in 1990 as a public interest institution under the Ministry of Social Affairs. MHF play an important role in informing and protecting their members and in cooperating with health care practitioners and institutions to preserve quality and accessibility of health care. The NBB and the FSMA shall conclude cooperation agreements with the Control Office on MHF, which govern, inter alia, exchange of information and the uniform application of regulatory requirements. Given the non-commercial nature of the MHF and the government funding, they are excluded from the scope of the current assessment.

\section{Preconditions for Effective Insurance Supervision}

\section{Sound and sustainable macroeconomic and financial sector policies}

\section{The macroeconomic and fiscal framework of Belgium is partly shaped by its} membership in the EU. NBB is a part of the European System of Central Banks (ESCB), with price stability as the primary objective for monetary policy. In response to the financial crisis which began in end-2008 and the sovereign debt crisis since 2010, the European Central Bank (ECB) made some fundamental changes to its monetary policy stance and took a series of exceptional measures to support the financial sector and safeguard the effective transmission of monetary policy.

\section{At the time of assessment, the authorities do not perceive the Belgian economy to present major imbalances that would threaten the stability of the Belgian financial system.} Nonetheless, financial tensions in the Euro area, sluggish growth prospect and the high level of public debt remain sources of vulnerabilities and negative developments in terms of external competitiveness are concerns to be addressed. The sustainability of public finances is further exacerbated by the budgetary impact arising from an aging population. Going forward, fiscal consolidation, structural reforms in the labor market and strengthening competitiveness are key policy objectives.

\section{A well-developed public infrastructure}

39. The legal system in Belgium is developed and constituted by a hierarchy of laws. As a member of the EU, Belgium also has to transpose European Directives into Belgian law. The Constitution is the highest-ranking and defines, inter alia, the organization of the State, including empowering the Parliament to pass laws. A law may authorise the King to adopt Royal Decrees or 
Ministers to take Ministerial Decrees in order to execute the law. A law may also delegate administrative authority to the NBB to issue legally binding regulations. Regulations proposed by the NBB are subject to the approval by a Royal Decree or Ministerial Decree, to respect the principle of democracy. The independence of the judiciary is respected. ${ }^{11}$ As a member of the EU, the authorities also make necessary legislative and regulatory amendments to transpose European Directives into Belgian law.

\section{Accounting and auditing standards adopted in Belgium are in line with international best practices. While the Commission for Accounting Principles oversees the Belgian General} Accounting, the NBB is responsible for specific rules applicable to insurance accounting. Belgian insurers are required, as of 2012 , to publish consolidated accounts in accordance with the International Financial Reporting Standards. Only external auditors accredited by the NBB may be appointed by insurers and they are expected to contribute to the NBB's supervisory process and they are obliged to notify the NBB on specified matters e.g., breaches of the law or qualified opinion. External auditors must be members of the Institute of External Auditors; a body that oversees observance of auditing as well as the competence and independence of its members. Belgian auditing standards are compliant with International Auditing Standards issued by the International Auditing and Assurance Standards Board.

\section{The Institute of Actuaries of Belgium establishes professional and ethical standards for} its members. There are more than 830 qualified actuaries registered with the Institute. The actuarial training syllabus in Belgium has been developed in line with the Groupe Consultatif's Core Syllabus for actuarial training in Europe and International Actuarial Association education guidelines. The Institute requires members to fulfill continuing professional development to remain up-to-date. While the Institute is empowered to take disciplinary action against its members for failing to perform their tasks in line with the international professional guidelines, no such action has been taken to date. The Insurance Law does not establish a statutory role for actuaries, who are also not subject to whistle blowing obligations to the NBB.

\section{The NBB provides comprehensive macroeconomic statistics for the public on its} website and via its statistical database, Belgostat. It collects and compiles extensive statistics on various facets of the economic and financial activities in Belgium. The integration of its microprudential and macro-prudential roles under the twin-peak structure is expected to improve the efficiency and effectiveness of its statistical efforts. The statistics published by the NBB include: a) national account; b) financial accounts identifying the financial instruments in which the various economic sectors place their surpluses or finance their deficits; c) Belgian budget balance and public debt; d) balance of payments; e) monetary and financial statistics; and f) business surveys.

\footnotetext{
${ }^{11}$ The Belgian Constitution of February 17, 1994 guarantees the independence of judges when exercising their jurisdictional powers; and no judge may be removed or suspended from office unless by judgment. In its Global Competitiveness Report 2012, the World Economic Forum ranked Belgium highly on judicial independence (28 out of 144 ) while efficiency of legal framework was ranked $45^{\text {th }}$. http://www3.weforum.org/docs/WEF GlobalCompetitivenessReport 2012-13.pdf
} 


\section{Effective market discipline in financial markets}

43. Several structures and frameworks foster the effective functioning of market discipline in Belgium. The regulated stock exchange (Euronext) is subject to investor protection and governance rules, information disclosure requirements and supervision by the FSMA. Most of the requirements on investor protection and information disclosure are based on relevant EU Directives.

44. Belgium's corporate governance system is in line with the Organization for Economic Cooperation and Development's Principles of Corporate Governance. The authorities have issued a cross-sectoral Internal Governance Circular for the financial sector, adopting a comply-orexplain approach (ICP 7).

\section{Mechanisms for consumer protection}

45. The legal framework for consumer protection is well established under a number of legislation: the Civil Code, the Law of 6 April 2010 on trade practices and consumer protection (TP\&CP Law), Law of 25 June 1992 on terrestrial insurance policies (TIP Law) and the Law of 2 August 2002 on the supervision of the financial sector and on financial services (Supervision Law). The Insurance Ombudsman mediates disputes between policyholder and their insurers/intermediaries, at no cost to the policyholders. The opinion of the Ombudsman is not binding.

46. Since 2008, policyholders of traditional life policies (except for group insurance related to employee benefits) are covered by the Deposit Guarantee Scheme up to $€ 100,000$ per policyholder. The Resolution Fund, which is partially pre-financed by the banking sector, may potentially be used to intervene to finance the resolution of insurers.

\section{Efficient financial markets}

47. The financial markets in Belgium offer a broad range of instruments that facilitate insurers' asset-liability management. As at end-2011, insurers held only 3 percent of their assets with the dominant banking sector, with more than 60 percents of their investments in fixed income securities (Table 5). Total fixed income securities of more than one year outstanding as at end-2011 amounted to $€ 813$ billion. ${ }^{12}$ In September 2000, the Brussels Exchanges ${ }^{13}$ merged with the Paris Bourse and Amsterdam Exchanges to form Euronext, the first pan-European exchange. It is part of the NYSE Euronext group, the cross-border exchange group created in 2007 by the combination of NYSE Group, Inc. and Euronext N.V. There are approximately 8,000 issues listed on NYSE Euronext (excluding structured products) - which accounts for one-third of the world's equities trading and one of the leading futures and options trading venues.

\footnotetext{
12 Table 17.1.1., Quarterly Financial Statistics 2012-II.

${ }^{13}$ In April 1999, the Brussels Exchanges was established as an integrated market operator comprised of Belfox (Belgian Futures and Options Exchange), Bourse de Bruxelles (Brussels stock exchange) and CIK (the central securities depository).
} 
Table 9: Summary of Compliance with the ICPs

\begin{tabular}{|c|c|c|}
\hline Insurance Core Principle & Level & \\
\hline $\begin{array}{l}\text { 1. Objectives, Powers and } \\
\text { Responsibilities of the } \\
\text { Supervisor }\end{array}$ & LO & $\begin{array}{l}\text { The responsibilities for insurance supervision in Belgium are clearly } \\
\text { defined under the Twin Peak supervisory structure, which has been } \\
\text { implemented for less than two years. The NBB and the FSMA have } \\
\text { clear mandates under the Twin Peaks structure, which also enhances } \\
\text { checks-and-balances. The objectives of the supervision of insurers } \\
\text { and reinsurer are defined in the primary legislations. The NBB may } \\
\text { establish enforceable rules within the parameters specifically } \\
\text { prescribed in the primary law, subject to the approval of the King or } \\
\text { a Minister. }\end{array}$ \\
\hline 2. Supervisor & $\mathrm{PO}$ & $\begin{array}{l}\text { The NBB and the FSMA have financial independence in exercising } \\
\text { their functions and powers and they are subject to clear } \\
\text { accountability mechanisms. Both the supervisors and their staff } \\
\text { members are legally obliged to safeguard confidential information } \\
\text { and have the necessary legal protection against civil liability except } \\
\text { for fraud or gross negligence. } \\
\text { While the NBB and the FSMA have budgetary discretion, there is a } \\
\text { need to strengthen their supervisory resources to achieve } \\
\text { appropriate supervisory intensity and effectiveness. There are } \\
\text { explicit procedures for the appointment and dismissal of the } \\
\text { members of the governing bodies of the NBB and the FSMA, and } \\
\text { the Belgian Administrative Law provides for transparency of the } \\
\text { reasons for their dismissals. There is an established policy on the } \\
\text { composition of the NBB Board in terms of diversity of experience } \\
\text { and skill set. The lack of internal policy and procedure to ensure } \\
\text { prompt escalation of significant events and the lack of authority for } \\
\text { the NBB to declare its decisions to take recovery measures as } \\
\text { immediately executable may hinder timely intervention by the NBB. } \\
\text { There is scope for strengthening the resources of the Internal Audit } \\
\text { Service to provide quality assurance on the integrity of supervisory } \\
\text { activities of the NBB. }\end{array}$ \\
\hline $\begin{array}{l}\text { 3. Information Exchange and } \\
\text { Confidentiality Requirements }\end{array}$ & $\mathrm{O}$ & $\begin{array}{l}\text { The framework for information exchange in Belgium is aligned with } \\
\text { the relevant EU Directives and protocols, empowering the NBB to } \\
\text { obtain and exchange information with relevant supervisors and } \\
\text { authorities subject to confidentiality, purpose and use requirements. } \\
\text { The existence of an agreement or understanding on information } \\
\text { exchange is, generally, not a prerequisite for information exchange. } \\
\text { The NBB may share information with non-EEA supervisors on a } \\
\text { reciprocal basis or pursuant to cooperation agreements. } \\
\text { Internationally, the NBB is signatory to the IAIS Multilateral MoU. } \\
\text { The NBB also participates actively in relevant supervisory colleges, } \\
\text { where information exchanges are to be facilitated by coordination } \\
\text { arrangements agreed by the colleges. However, the coordination } \\
\text { arrangements are not yet signed officially, pending the } \\
\text { implementation of Solvency II. } \\
\text { Domestically, the MoU between the NBB and the FSMA as required } \\
\text { under the Insurance Law was under discussion at the time of } \\
\text { assessment. There is also scope for the FSMA and the NBB to review }\end{array}$ \\
\hline
\end{tabular}




\begin{tabular}{|c|c|c|}
\hline & & $\begin{array}{l}\text { how best to strengthen supervisory cooperation as they gain } \\
\text { experience in implementing the twin-peaks structure. }\end{array}$ \\
\hline 4. Licensing & $\mathrm{O}$ & $\begin{array}{l}\text { Insurance activities within Belgium can only be conducted by } \\
\text { authorized insurers/ reinsurers. The NBB is the licensing authority } \\
\text { and the requirements and procedures for obtaining authorisation } \\
\text { are clearly defined, objective and public. While regulated insurance } \\
\text { activities is not defined positively in the Insurance Law, the NBB } \\
\text { makes reference to definition of "insurance contract" under the Law } \\
\text { on Terrestrial Insurance Contract and has provided binding ruling on } \\
\text { insurance activities. A multidisciplinary team evaluate applications } \\
\text { for authorization in accordance with established internal procedures, } \\
\text { taking account of the FSMA's opinion. } \\
\text { A draft Royal Decree has been prepared to provide partial } \\
\text { exemptions to mutual insurance associations and cooperative } \\
\text { societies that limit their activities to the municipality where their } \\
\text { registered office is located, or to that municipality and neighbouring } \\
\text { municipalities. The NBB has not taken action against the non- } \\
\text { compliance with the authorisation requirement by certain mutual } \\
\text { insurance associations and cooperative societies on the basis of that } \\
\text { their operations are limited in scale; and these institutions would not } \\
\text { fall within the scope of the draft Royal Decree nor the future } \\
\text { Solvency II rules. }\end{array}$ \\
\hline 5. Suitability of Persons & LO & $\begin{array}{l}\text { The NBB assesses the fitness and propriety of Board Members and } \\
\text { Senior Management at the stage of proposed appointment and re- } \\
\text { appointment, based on comprehensive information and extensive } \\
\text { deliberation. It is in the process of revising its fit and proper } \\
\text { regulation in line with international best practices and the key } \\
\text { enhancements include: extending the suitability requirements to Key } \\
\text { Persons in Control Functions; requiring notifications by insurers of } \\
\text { circumstances that may materially adversely affect the suitability of } \\
\text { persons and greater clarity on the criteria for fitness and propriety. }\end{array}$ \\
\hline $\begin{array}{l}\text { 6. Changes in Control and } \\
\text { Portfolio Transfers }\end{array}$ & $\mathrm{O}$ & $\begin{array}{l}\text { The Insurance Law defines qualifying holdings and set the } \\
\text { thresholds for the acquisition of and increase/decrease in qualifying } \\
\text { holdings, which require the prior approval of the NBB. The criteria } \\
\text { for assessing acquisition proposals are the same as those applicable } \\
\text { for initial authorization applications. Insurers are required to: a) } \\
\text { notify the NBB of changes in qualifying holdings that would result in } \\
\text { a person's holdings either to exceed or to fall below the specified } \\
\text { thresholds; and b) submit the names of their Significant Owners } \\
\text { annually. Portfolio transfers are subject to the approval of the NBB, } \\
\text { to protect the rights of policyholders, insureds and beneficiaries. } \\
\text { The NBB and the FSMA do not have the power to approve or } \\
\text { oppose the conversion of a mutual company to a stock company. } \\
\text { Nonetheless, they are expected to comment on the conversion } \\
\text { proposal and may intervene through indirect means, if necessary. } \\
\text { Such conversion has been rare in Belgium. }\end{array}$ \\
\hline 7. Corporate Governance & LO & $\begin{array}{l}\text { Since the last assessment in 2006, the authorities have significantly } \\
\text { strengthened the regulation and supervision of insurers' corporate } \\
\text { governance, by adopting legally binding minimum requirements in } \\
\text { the field of governance, supplemented by a comply-or-explain }\end{array}$ \\
\hline
\end{tabular}




\begin{tabular}{|c|c|c|}
\hline & & $\begin{array}{l}\text { approach that is supported by detailed supervisory guidance. The } \\
\text { NBB's assessment of insurers' governance practices is a key input in } \\
\text { the Scorecard System and in prioritising it risk-based supervision. } \\
\text { The authorities are in the process of updating the Internal } \\
\text { Governance Circular to take account of evolving international best } \\
\text { practices. }\end{array}$ \\
\hline $\begin{array}{l}\text { 8. Risk Management and } \\
\text { Internal Controls }\end{array}$ & 0 & $\begin{array}{l}\text { The authorities have established sophisticated principles-based risk } \\
\text { management and internal control system requirements. Stronger } \\
\text { requirements apply to insurers who are exempted from the Flashing } \\
\text { Light provisions. The external auditors play a substantial role in } \\
\text { reviewing insurers' reports to the NBB on their internal control } \\
\text { system (refer to ICP 9). }\end{array}$ \\
\hline $\begin{array}{l}\text { 9. Supervisory Review and } \\
\text { Reporting }\end{array}$ & LO & $\begin{array}{l}\text { The NBB has introduced an integrated risk assessment framework } \\
\text { that is supported by a risk-based supervisory process. The } \\
\text { supervisory framework integrates vertical analyses of individual } \\
\text { insurers with horizontal review of the insurance sector as a whole, } \\
\text { while leveraging on the macroeconomic competencies of the NBB. } \\
\text { Checks-and-balances in supervisory assessment have been } \\
\text { enhanced through the separation of vertical and horizontal } \\
\text { supervision as well as the off-site review and on-site inspections. } \\
\text { The four-eye-principle approach also promotes active sharing of } \\
\text { experiences across functions. The NBB has also established policies } \\
\text { and procedures with respect to the contributions of the accredited } \\
\text { auditors' contribution to the supervisory process. } \\
\text { The Scorecard system facilitates proper documentation and } \\
\text { consistency of supervisory assessments as well as providing a } \\
\text { structured framework to discuss supervisory issues; both internally } \\
\text { and with insurers. The intensity of supervisory engagement is } \\
\text { prioritized based on a risk-based approach. The NBB is empowered } \\
\text { to collect extensive regulatory and statistical information from } \\
\text { insurers and the reporting obligation applies at both the solo and } \\
\text { group levels. Since January } 2012 \text {, the NBB has been conducting on- } \\
\text { site inspection based on audit techniques, with clear scoping and } \\
\text { formalized work program. It issues formal reports on its findings and } \\
\text { remedial measures and monitors the implementation of required } \\
\text { measures. NBB may inspect service providers of outsourced } \\
\text { functions but has not conducted such inspections. } \\
\text { As the current supervisory framework is new, the NBB has been } \\
\text { monitoring the implementation experience and practical issues that } \\
\text { arise. A methodological review exercise is ongoing across prudential } \\
\text { departments with the view to further enhancing supervisory } \\
\text { effectiveness. The NBB has also recently decided to implement } \\
\text { certain elements of Solvency II ahead of the official implementation } \\
\text { schedule and this would improve the coverage and quality of } \\
\text { regulatory reporting. It is also critical that the NBB carefully plan for } \\
\text { batequate resources to conduct effective supervision supported by a } \\
\text { refinere is minimal regulatory }\end{array}$ \\
\hline
\end{tabular}




\begin{tabular}{|c|c|c|}
\hline & & $\begin{array}{l}\text { reporting by insurers and intermediaries, which hinders the } \\
\text { formulation of risk-based supervision plans. On-site visits of insurers } \\
\text { are typically driven by external triggers while the inspections of } \\
\text { intermediaries focus mainly on compliance with registration } \\
\text { requirements. }\end{array}$ \\
\hline $\begin{array}{l}\text { 10. Preventive and Corrective } \\
\text { Measures }\end{array}$ & $\mathrm{O}$ & $\begin{array}{l}\text { Unauthorized insurance activities constitute an offence under the } \\
\text { Insurance Law and the NBB and FSMA may refer such cases for } \\
\text { prosecution. The NBB has, at its disposal, a range of preventive and } \\
\text { corrective measures that supports the progressive escalation of } \\
\text { actions. Before taking such measures, the NBB exercises moral } \\
\text { suasion and works with the insurers concerned to rectify any } \\
\text { deficiencies within a specified timeframe. }\end{array}$ \\
\hline 11. Enforcement & $\mathrm{O}$ & $\begin{array}{l}\text { The NBB and the FSMA have a wide range of powers to take } \\
\text { enforcement action and impose sanctions, if insurers are unable or } \\
\text { unwilling to address supervisory concerns in a timely manner. A } \\
\text { transparent process and the engagement of the Sanctions } \\
\text { Committees (to be established) in the NBB and of the Sanctions } \\
\text { Committee of the FSMA helps to ensure proportionate and } \\
\text { consistent sanction decisions. }\end{array}$ \\
\hline $\begin{array}{l}\text { 12. Winding-up and Exit from } \\
\text { the Market }\end{array}$ & $\mathrm{O}$ & $\begin{array}{l}\text { The winding-up of insurers is based on the procedure set out in the } \\
\text { Insolvency Law (insolvency) and the Company Code (dissolution and } \\
\text { liquidation), subject to certain insurance-specific modifications set } \\
\text { out in the Insurance Law. Policyholders have priority of claim above } \\
\text { other unsecured creditors in the event of a winding-up. The } \\
\text { Insurance Law that determines the point at which it is no longer } \\
\text { permissible for an insurer to continue its business. }\end{array}$ \\
\hline $\begin{array}{l}\text { 13. Reinsurance and Other } \\
\text { Forms of Risk Transfer }\end{array}$ & LO & $\begin{array}{l}\text { The NBB requires insurers to submit comprehensive information on } \\
\text { their reinsurance programs and its IT Tool calculates standard early } \\
\text { warning indicators automatically. Reinsurance is taken into account } \\
\text { in the PCR (solvency margin) using rough proxies and the risk } \\
\text { mitigating effect might be under- or overstated for some forms of } \\
\text { reinsurance (e.g., for non-proportional covers). This has to be } \\
\text { balanced with the resources required to perform a more detailed } \\
\text { analysis, particularly for complex reinsurance programs. Reinsurance } \\
\text { credit risks (default and migration risk) are not considered } \\
\text { adequately, which may hinder the early detection of deteriorating } \\
\text { credit quality of reinsurers. Similarly, concentration risk arising from } \\
\text { reinsurance ceded to only one or few reinsurers is not considered. }\end{array}$ \\
\hline 14. Valuation & $\mathrm{LO}$ & $\begin{array}{l}\text { The valuation of assets and liabilities for solvency purposes must } \\
\text { conform to applicable accounting standards at both solo (BGAAP) } \\
\text { and group level (IFRS). The valuation approach for assets covering } \\
\text { TP is generally market-based, except for sovereign bonds, which are } \\
\text { valued at amortized cost less depreciation/impairment. TP are } \\
\text { valued at historical cost. } \\
\text { Arising from the supervisors' observation that some insurers have } \\
\text { not applied the valuation approach (notably on impairments) with } \\
\text { the expected rigor, the NBB has reviewed insurers' valuation of } \\
\text { certain assets in more depth since the financial crisis and has taken } \\
\text { action against insurers to address any solvency concerns. } \\
\text { The NBB focuses mainly on the level of TP and less on the methods }\end{array}$ \\
\hline
\end{tabular}




\begin{tabular}{|c|c|c|}
\hline & & $\begin{array}{l}\text { used to calculate TP. The current valuation standard for TP is based } \\
\text { on implicit prudence without an explicit current estimate and MOCE } \\
\text { (Margin over Current Estimate). This makes the analysis of the } \\
\text { sufficiency of TP more difficult for the NBB. }\end{array}$ \\
\hline 15. Investment & LO & $\begin{array}{l}\text { The regulatory requirements on investments are in line with EU } \\
\text { Directives, which apply only the assets covering insurers' TP i.e., } \\
\text { there are no requirements on free assets. ALM requirements for } \\
\text { some insurers have been implemented since } 2006 \text { in relation to the } \\
\text { Flashing Light provision and there is scope for updating the } \\
\text { prudential standard to reflect evolving best practices. In addition, } \\
\text { insurers have to formulate crisis scenarios and quantify the impact } \\
\text { as part of their ALM framework. Effective supervision of insurers' } \\
\text { ALM hinges on adequate technical supervisory capacity. }\end{array}$ \\
\hline $\begin{array}{l}\text { 16. Enterprise Risk } \\
\text { Management for Solvency } \\
\text { Purposes }\end{array}$ & LO & $\begin{array}{l}\text { The current prudential standards have established some elements of } \\
\text { the regulatory requirements for an enterprise risk management by } \\
\text { insurers. To meet ICP 16, there should be clearer requirements and } \\
\text { more comprehensive scope on insurers' risk management policy, } \\
\text { particularly for investment and underwriting risks. In addition, } \\
\text { enterprise risk management should be supported by an ORSA. } \\
\text { Currently, some elements of ORSA are applicable only to those } \\
\text { insurers that are exempted from the Flashing Light provision. }\end{array}$ \\
\hline 17. Capital Adequacy & $\mathrm{PO}$ & $\begin{array}{l}\text { The current Solvency I framework is not risk-based-the capital } \\
\text { requirement does not take all material risk into account, e.g., credit } \\
\text { risk, and if risks are taken into account, this is not done explicitly. } \\
\text { The capital requirement is also not consistent with the valuation } \\
\text { standard. Capital adequacy does not explicitly consider the } \\
\text { following factors on a realistic basis: asset liability matching; } \\
\text { reinsurance and other risk mitigating measures; or diversification } \\
\text { between risks. } \\
\text { Group capital requirements are also based on Solvency I, which does } \\
\text { not take into account group-specific risks e.g., contagion risks. } \\
\text { While there are two solvency control levels, the MCR is not a } \\
\text { minimum bound below which no insurer is regarded to be viable to } \\
\text { operate effectively, i.e., there is no solvency control level which leads } \\
\text { to an automatic strongest supervisory actions in the absence of } \\
\text { appropriate corrective action by an insurer. }\end{array}$ \\
\hline 18. Intermediaries & LO & $\begin{array}{l}\text { Although the registration conditions for intermediaries are clear and } \\
\text { transparent and the training and qualification requirements imposed } \\
\text { by the FSMA comply with the IMD directive at the European level, } \\
\text { there is scope to raise the level of continuous professional } \\
\text { development requirements. The FSMA's supervision of } \\
\text { intermediaries focuses mainly on checking compliance with } \\
\text { registrations requirements to limit access by qualified and fit and } \\
\text { proper intermediaries. While the pre-contract information disclosure } \\
\text { provides adequate information on an intermediary's status and } \\
\text { relationship with insurers, there is scope for enhancing disclosure on } \\
\text { potential conflict of interest, particularly relating to remuneration } \\
\text { arrangements. The FSMA conducts on-site inspections of } \\
\text { intermediaries and has withdrawn or suspended the registrations of } \\
\text { intermediaries who failed to meet its requirements. The legal }\end{array}$ \\
\hline
\end{tabular}




\begin{tabular}{|c|c|c|}
\hline & & $\begin{array}{l}\text { framework provides protection for clients monies handled through } \\
\text { intermediaries. } \\
\text { To supervise a large numbers of intermediaries with limited } \\
\text { resources, it is advisable that the FSMA develops an appropriate } \\
\text { risk-based approach, supported by explicit and proportionate } \\
\text { corporate governance requirements for intermediaries. }\end{array}$ \\
\hline 19. Conduct of Business & LO & $\begin{array}{l}\text { The current regulatory regime on CoB focuses on prohibition } \\
\text { against unfair and misleading practices. The implementation of the } \\
\text { voluntary moratorium of structured products that are considered as } \\
\text { "particularly complex" in August } 2011 \text { is a commendable supervisory } \\
\text { initiative. The emerging international best practices are to promote } \\
\text { fair treatment of customers that are an integral part of business } \\
\text { culture of insurers and intermediaries. In this regard, the FSMA has } \\
\text { proposed amendments to the Supervision Law to impose a general } \\
\text { obligation on insurers and insurance intermediaries to act fairly, } \\
\text { honestly and professionally in the best interests of their clients and } \\
\text { provide correct, clear and not misleading information. The proposed } \\
\text { adaptation of MiFID } 2 \text { to insurance meditation will enhance CoB } \\
\text { requirements. }\end{array}$ \\
\hline 20. Public Disclosure & $\mathrm{PO}$ & $\begin{array}{l}\text { The current disclosure regime in Belgium focuses on the financial } \\
\text { position and performance of insurers and there are significant gaps } \\
\text { in the disclosures on: technical provisions, risk management and } \\
\text { exposures, details of performance and capital adequacy. The } \\
\text { application of IFRS as from financial year } 2012 \text { has improved the } \\
\text { disclosures made in consolidated accounts. The impending } \\
\text { implementation of Solvency II will bring the disclosure regime in line } \\
\text { with international best practices. }\end{array}$ \\
\hline $\begin{array}{l}\text { 21. Countering Fraud in } \\
\text { Insurance }\end{array}$ & $\mathrm{O}$ & $\begin{array}{l}\text { While there is no specific legislation on insurance fraud, the general } \\
\text { criminal law adequately addresses fraudulent conduct relating to } \\
\text { insurance, which are subject to criminal proceedings. Supervisory } \\
\text { attention for fraud is part of the assessments relating to } \\
\text { governance/risk management, compliance and internal audit } \\
\text { functions (where applicable) of insurers. The insurance industry has } \\
\text { taken measures to counter fraud such as training programs, sharing } \\
\text { information via databases and a new code of conduct concerning } \\
\text { insurance fraud prevention. The NBB and FSMA may cooperate, } \\
\text { coordinate and exchange information relating to insurance frauds } \\
\text { with other competent authorities, including foreign authorities. }\end{array}$ \\
\hline $\begin{array}{l}\text { 22. Anti-Money Laundering and } \\
\text { Combating the Financing of } \\
\text { Terrorism }\end{array}$ & $\mathrm{O}$ & $\begin{array}{l}\text { The NBB and FSMA are aware of the money laundering and } \\
\text { terrorism financing risks of the insurance industry and have effective } \\
\text { mechanisms to cooperate, coordinate and exchange information } \\
\text { with both domestic and foreign supervisors/FIUs. The authorities are } \\
\text { reviewing the current AML-CFT regime to take account of the new } \\
\text { FATF Recommendations of February } 2012 \text {. }\end{array}$ \\
\hline 23. Group-wide Supervision & LO & $\begin{array}{l}\text { The supplementary supervision of insurance groups in Belgium is } \\
\text { shaped by EU Directive and facilitated by a structured coordination } \\
\text { framework at the EU level organized by EIOPA. The NBB has } \\
\text { adequate powers and flexibility to determine the scope of insurance } \\
\text { groups as well as to supervise and take appropriate measures } \\
\text { against both regulated and non-regulated entities within a group. } \\
\text { The NBB is actively involved in supervisory colleges, both as a home }\end{array}$ \\
\hline
\end{tabular}




\begin{tabular}{|c|c|c|}
\hline & & $\begin{array}{l}\text { and host supervisor (ICP 25). } \\
\text { However, there are no group-wide market conduct requirements. } \\
\text { There is also scope for establishing consistent supervisory processes } \\
\text { for group supervision e.g., in reporting intra-group transactions. } \\
\text { Although the NBB has concluded supervisory cooperation } \\
\text { agreements with other insurance supervisors, there is scope for } \\
\text { improvement. To this end, the supervisory colleges are taking up } \\
\text { this work under the aegis of EIOPA. }\end{array}$ \\
\hline $\begin{array}{l}\text { 24. Macroprudential } \\
\text { Surveillance and Insurance } \\
\text { Supervision }\end{array}$ & 0 & $\begin{array}{l}\text { As the central bank and prudential supervisor, the NBB is well placed } \\
\text { in achieving effective macroprudential surveillance. It collects } \\
\text { extensive quantitative and qualitative information quarterly, } \\
\text { complemented by ad-hoc questionnaires, if necessary. Its } \\
\text { Macrofinancial Committee serves as a forum for the exchange of } \\
\text { information on macro-financial developments in Belgium and in } \\
\text { countries where Belgian institutions have exposure. The Risk } \\
\text { Committee oversees cross-sectoral risk analyses by risks areas to } \\
\text { facilitate early detection of potential systemic threats/ risks. The NBB } \\
\text { participates in the EIOPA stress testing exercises and conducts its } \\
\text { own stress tests of the Belgian insurance sector. } \\
\text { Given that macro-prudential surveillance is a nascent development, } \\
\text { the NBB plans to regularly review the integration of macro- } \\
\text { prudential analyses and assessments into its micro-prudential } \\
\text { supervision to identify further refinements. }\end{array}$ \\
\hline $\begin{array}{l}\text { 25. Supervisory Cooperation } \\
\text { and Coordination }\end{array}$ & 0 & $\begin{array}{l}\text { In preparation for the implementation of Solvency II, the NBB has } \\
\text { established comprehensive coordination arrangements with other } \\
\text { involved supervisors to facilitate effective supervision on a legal- } \\
\text { entity and a group-wide basis. The NBB chairs three supervisory } \\
\text { colleges as the group-wide supervisor, with the mandate to } \\
\text { establish the key functions and other coordination mechanisms of } \\
\text { these colleges. Where appropriate, the NBB coordinates with } \\
\text { relevant agencies from other sectors, including central banks and } \\
\text { government ministries. Pending the implementation of Solvency II, } \\
\text { the coordination arrangements have not been concluded for all } \\
\text { insurance groups although all the colleges have been operating in } \\
\text { line with the EIOPA's templates. The NBB became a signatory to the } \\
\text { IAIS Multilateral MoU in December } 2011 \text {, facilitating cross-border } \\
\text { cooperation with non-EEA members who are signatories to this } \\
\text { multilateral MoU. }\end{array}$ \\
\hline $\begin{array}{l}\text { 26. Cross-border Cooperation } \\
\text { and Coordination on Crisis } \\
\text { Management }\end{array}$ & LO & $\begin{array}{l}\text { The Belgian regime for cross-border cooperation and coordination } \\
\text { on crisis management is based on the EU framework, which has } \\
\text { been partially operationalized. The EU Framework supports and } \\
\text { provides guidance on coordinating the arrangements for crisis } \\
\text { preparation, management and resolution by supervisory colleges in } \\
\text { EU. However, coordination arrangements and emergency plans have } \\
\text { not yet been implemented for all supervisory colleges that the NBB } \\
\text { participates in. Some insurance groups are still in the process of } \\
\text { developing their contingency plans. }\end{array}$ \\
\hline
\end{tabular}

Aggregate Level: Observed (O), largely observed (LO), partly observed (PO), not observed (NO), not applicable (N/A). 
Table 10: Summary of Observance Level

\begin{tabular}{|l|c|}
\hline Observed (O) & 12 \\
\hline Largely observed (LO) & 11 \\
\hline Partly observed (PO) & 3 \\
\hline Not Observed (NO) & 0 \\
\hline Total & $\mathbf{2 6}$ \\
\hline
\end{tabular}

\section{Table 11: Recommendations to Improve Observance of ICPs}

\begin{tabular}{|c|c|}
\hline \multicolumn{2}{|l|}{\begin{tabular}{|l|} 
Insurance Core Principle \\
\end{tabular}} \\
\hline $\begin{array}{l}\text { 1. Objectives, Powers and Responsibilities } \\
\text { of the Supervisor }\end{array}$ & $\begin{array}{l}\text { The authorities are advised to: } \\
\text { a) Conduct regular reviews of the practical implementation of the } \\
\text { Twin Peaks structure, to identify and assess any potential gaps, } \\
\text { duplication or coordination issues to ensure that supervisory } \\
\text { objectives for the insurance sector are effectively achieved; and } \\
\text { b) Consider a more principle-based approach in delegating legal } \\
\text { authority to the NBB to issue enforceable rules. }\end{array}$ \\
\hline 2. Supervisor & $\begin{array}{l}\text { The authorities are advised to: } \\
\text { a) Rectify the NBB Organic Law to enable the NBB to declare its } \\
\text { decisions to take recovery measures with respect to insurers as } \\
\text { immediately executable, notwithstanding an appeal; } \\
\text { b) Ensure that the NBB and FSMA have adequate supervisory } \\
\text { resources to achieve the appropriate supervisory intensity and } \\
\text { effectiveness, including a baseline supervisory program (ICP 9); } \\
\text { consider clarifying that the scope and circumstances for } \\
\text { Minister's supervision of the NBB's "transactions" does not } \\
\text { cover the its supervisory activities; } \\
\text { d) Establish clear policies, procedures and decision making lines } \\
\text { to ensure prompt escalation of significant issues to appropriate } \\
\text { levels within the NBB as well as in cases of emergency; and } \\
\text { e) Review the adequacy of resources of the Internal Audit Service } \\
\text { of the NBB to provide assurance on the integrity of its } \\
\text { supervisory activities. }\end{array}$ \\
\hline $\begin{array}{l}\text { 3. Information Exchange and } \\
\text { Confidentiality Requirements }\end{array}$ & $\begin{array}{l}\text { The authorities are advised to expedite the conclusion of the MoU } \\
\text { between the NBB and the FSMA to guide effective cooperation and } \\
\text { exchange of information. }{ }^{14}\end{array}$ \\
\hline 4. Licensing & $\begin{array}{l}\text { The authorities are advised to expedite the finalisation of the draft } \\
\text { Royal Decree establishing proportionate regulatory requirements for }\end{array}$ \\
\hline
\end{tabular}

\footnotetext{
${ }^{14}$ Following the FSAP mission, a general MOU on collaboration between the NBB and the FSMA to ensure coordination of the supervision of institutions under the respective supervision of the two agencies has been concluded on March 14, 2013.
} 


\begin{tabular}{|c|c|}
\hline & local mutual insurance associations and cooperative societies. \\
\hline 5. Suitability of Persons & $\begin{array}{l}\text { The authorities are advised to expedite the revision of the fit and } \\
\text { proper regulation. }\end{array}$ \\
\hline $\begin{array}{l}\text { 6. Changes in Control and Portfolio } \\
\text { Transfers }\end{array}$ & $\begin{array}{l}\text { The authorities are advised to consider empowering the NBB and } \\
\text { FSMA to approve the conversion of the mutual companies to stock } \\
\text { companies, to better safeguard the interests of policyholder and } \\
\text { beneficiaries. }\end{array}$ \\
\hline 7. Corporate Governance & $\begin{array}{l}\text { The corporate governance framework could be enhanced by } \\
\text { establishing clearer and explicit supervisory expectation on: } \\
\text { a) the duties for directors to act in a manner that would not } \\
\text { compromise the interests of an insurer and policyholders, } \\
\text { particularly in a group context; and } \\
\text { b) adequate powers and resources for the Board of directors to } \\
\text { exercise effective oversight. }\end{array}$ \\
\hline 9. Supervisory Review and Reporting & $\begin{array}{l}\text { The authorities' decision to implement Solvency II ahead of the } \\
\text { official launch date is a positive initiative. In addition, the } \\
\text { effectiveness of on-going supervision could be strengthened by: } \\
\text { a) Developing an appropriate baseline supervisory program for } \\
\text { insurers/insurance groups according to their risk profiles; } \\
\text { b) Strategizing an appropriate risk-based CoB supervision by the } \\
\text { FSMA to cover the large number of registered entities, to better } \\
\text { prevent misconduct by insurers and intermediaries rather than } \\
\text { the current more reactive approach. To this end, it is advisable } \\
\text { for the authorities to empower the FSMA to establish } \\
\text { appropriate off-site reporting by insurers and intermediaries; } \\
\text { c) Reviewing the scope and effectiveness of leveraging on the } \\
\text { work of external auditors and actuaries in the supervisory } \\
\text { process; } \\
\text { d) Establishing internal policies for inspecting outsourced } \\
\text { functions by the NBB and FSMA; and } \\
\text { e) Ensuring that both the FSMA and the NBB are equipped with } \\
\text { adequate supervisory resources including the technical capacity } \\
\text { to achieve the appropriate coverage and supervisory intensity. }\end{array}$ \\
\hline $\begin{array}{l}\text { 13. Reinsurance and Other Forms of Risk } \\
\text { Transfer }\end{array}$ & $\begin{array}{l}\text { We recommend that the NBB: } \\
\text { a) Strengthen the prudential standards relating to reinsurance, } \\
\text { and requires insurers to embed the management of reinsurance } \\
\text { risk as part of their risk management framework, particularly } \\
\text { with respect to counterparty, concentration and liquidity risks } \\
\text { arising from reinsurance; and } \\
\text { b) Formulate appropriate standards applicable for risk transfer to } \\
\text { capital markets to facilitate better understanding of the } \\
\text { structure and operations of such arrangements. }\end{array}$ \\
\hline 14. Valuation & $\begin{array}{l}\text { Given that the adequacy of the TP is critical for the protection of } \\
\text { policyholders, it is important that the NBB enhance its supervisory } \\
\text { assessment to include explicit consideration of the underlying } \\
\text { assumptions and methods used to estimate the TP. In this regard, } \\
\text { the NBB is advised to further build technical capacity to conduct } \\
\text { supervisory reviews and consider how best to leverage on the } \\
\text { actuarial functions of insurers. } \\
\text { The risk of a protracted low-interest rate environment makes it }\end{array}$ \\
\hline
\end{tabular}




\begin{tabular}{|c|c|}
\hline & $\begin{array}{l}\text { important for supervisors to monitor the cost of insurance liabilities, } \\
\text { in particular for life insurers' legacy portfolios with high guarantees. } \\
\text { In a low interest rate environment, the cost of producing the } \\
\text { insurance liability cash flows becomes higher and the value of TP on } \\
\text { an economic basis increases. } \\
\text { While ICP } 14 \text { accepts amortized cost as an economic valuation, we } \\
\text { recommend that the NBB strengthen its Flashing Light approach } \\
\text { and put in place a sound market consistent valuation standard for } \\
\text { TP, either as a Pillar } 1 \text { or as a Pillar } 2 \text { requirement for all insurers. We } \\
\text { recommend that the NBB consider introducing a sound market } \\
\text { consistent valuation approach as part of its decision to implement } \\
\text { Solvency II ahead of the official timeline. Even as a Pillar } 2 \\
\text { requirement, this will give important information to the NBB and to } \\
\text { insurers, while providing the incentives for proper ALM. The current } \\
\text { Flashing Light provision - implemented since } 2006 \text { - might be a } \\
\text { basis for the NBB to extend an appropriate market consistent } \\
\text { valuation standard to all insurers. It would also support both the } \\
\text { NBB and insurers in the transition to Solvency II. }\end{array}$ \\
\hline 15. Investment & $\begin{array}{l}\text { The NBB is currently examining how the risks relating to a low } \\
\text { interest environment and the establishment of an adequate ALM } \\
\text { can be better monitored. The implementation of Solvency II will also } \\
\text { establish clearer supervisory expectations as part of insurers' own } \\
\text { risk and solvency assessment. The NBB also intends to enhance its } \\
\text { supervisory competences on ALM through advanced training and } \\
\text { development initiatives. } \\
\text { The mission supports the NBB's proposal to update the prudential } \\
\text { standards for ALM to reflect evolving international best practices } \\
\text { and strengthening supervisory capacity to assess insurers' ALM } \\
\text { practices. It is also advisable to establish formal regulatory } \\
\text { requirements on the investments of insurance groups. }\end{array}$ \\
\hline $\begin{array}{l}\text { 16. Enterprise Risk Management for } \\
\text { Solvency Purposes }\end{array}$ & $\begin{array}{l}\text { The NBB's decision to implement ORSA earlier than the official } \\
\text { Solvency II timeline will improve observance of ICP 16. For ORSA to } \\
\text { be truly effective as a supervisory tool and also as a management } \\
\text { tool for insurers, it needs to be supported by a sound valuation and } \\
\text { risk assessment framework. } \\
\text { Given the potential risk of a prolonged low-interest rate } \\
\text { environment with potentially declining interest rates, transparency } \\
\text { on the long-term financial/economic situation of insurers is } \\
\text { particularly important. As interest rates stay low, the high returns in } \\
\text { legacy portfolios are likely to put pressure on the financial position } \\
\text { of life insurers resulting in gradual deterioration of their financial } \\
\text { soundness. An ORSA with a market consistent valuation standard } \\
\text { helps to address this potential risk and would also function as an } \\
\text { early warning sign for both the NBB and the industry. }\end{array}$ \\
\hline 17. Capital Adequacy & $\begin{array}{l}\text { The NBB is aware of the shortcomings of Solvency I and has been } \\
\text { preparing for the implementation of Solvency II, which is likely to } \\
\text { remedy many of the drawbacks of Solvency I. In view of the further } \\
\text { delay in the introduction of Solvency II, the NBB has decided to } \\
\text { implement certain elements of Solvency II ahead of the official } \\
\text { timeline. In this regard, the NBB has been building up resources and }\end{array}$ \\
\hline
\end{tabular}




\begin{tabular}{|c|c|}
\hline & $\begin{array}{l}\text { know-how for internal models. } \\
\text { We recommend that the NBB, in planning for the early } \\
\text { implementation of certain elements of Solvency II: } \\
\text { a) Explores strengthening both the quantitative and } \\
\text { qualitative elements of the current solvency framework; e.g., ORSA } \\
\text { (ICP 16) and conducting quantitative impact studies with all } \\
\text { industry participants; } \\
\text { b) Works with the industry to improve the quality of the } \\
\text { calculation of the Solvency II market consistent balance sheet and } \\
\text { capital requirements, over time; } \\
\text { c) Enhances the prudential standards for intra-group } \\
\text { transactions, including transactions between insurers and banks } \\
\text { within a conglomerate, given the dominance of insurance groups } \\
\text { and conglomerates and the fact the Solvency I does not } \\
\text { incorporate group-risk realistically; } \\
\text { d) Formulates an appropriate stress testing and scenario } \\
\text { analysis framework to facilitate more robust assessment of insurers' } \\
\text { risk exposures to compensate for the lack of risk sensitivity of } \\
\text { Solvency I; and } \\
\text { e) Reviews the adequacy of supervisory resources to } \\
\text { implement the above measures and the eventual implementation } \\
\text { of Solvency II. }\end{array}$ \\
\hline 18. Intermediaries & $\begin{array}{l}\text { The FSMA's proposal to adapt MiFID } 2 \text { for insurance intermediation } \\
\text { will improve observance of ICP 18, when the measures are } \\
\text { implemented. In addition, it is advisable: } \\
\text { a) For the FSMA to review the effectiveness of the current } \\
\text { continuous professional development requirements and } \\
\text { establish appropriate regulatory threshold beyond which } \\
\text { intermediaries are expected to implement sound corporate } \\
\text { governance practices; and } \\
\text { b) For the authorities to amend the Intermediation Law to impose } \\
\text { a time limit for the migration of sub-agents to agents/brokers. }\end{array}$ \\
\hline 19. Conduct of Business & $\begin{array}{l}\text { The authorities is advised to strengthen the CoB regime by: } \\
\text { a) Implementing the proposed amendments to the Supervision } \\
\text { Law and the MiFID } 2 \text { requirements to better ensure fair } \\
\text { treatment of clients; } \\
\text { b) Empowering the FSMA to issue enforceable rules on: the } \\
\text { handling of claims and policy servicing by insurers; and fact- } \\
\text { finding of client's needs and financial circumstances as basis for } \\
\text { financial advice; and } \\
\text { c) Ensuring that the FSMA is adequately resourced to supervise } \\
\text { the CoB of insurers and intermediaries effectively. }\end{array}$ \\
\hline 20. Public Disclosure & $\begin{array}{l}\text { The authorities are advised to address the significant gaps in the } \\
\text { disclosure requirements identified. }\end{array}$ \\
\hline 21. Countering Fraud in Insurance & $\begin{array}{l}\text { The authorities are advised to empower the NBB and the FSMA to } \\
\text { issue enforceable rules requiring insurers and intermediaries to } \\
\text { report insurance fraud. }\end{array}$ \\
\hline $\begin{array}{l}\text { 22. Anti-Money Laundering and } \\
\text { Combating the Financing of Terrorism }\end{array}$ & $\begin{array}{l}\text { The authorities should periodically reconsider whether or not non- } \\
\text { life insurance should be covered by the AML/CTF regime in Belgium. }\end{array}$ \\
\hline 23. Group-wide Supervision & The implementation of Solvency II will enhance Belgium's \\
\hline
\end{tabular}


24. Cross-border Cooperation and Coordination on Crisis Management observance with ICP 23. It is important that the NBB carefully plan for adequate supervisory resources to supervise insurance groups, especially the complex cross-border groups that are domestic SIFIs.

The conclusion of the coordination arrangements and emergency plans will enable the NBB to implement cross-border cooperation and coordination on crisis management for insurance groups. The arrangements and plans should also be regularly tested by all involved supervisors to ensure their operational effectiveness and to detect any gaps in procedures or information. In addition, the authorities are advised to consider empowering the NBB to require insurers and insurance groups to establish crisis management plans or contingency plans for use in a going- and gone-concern situation.

\section{Authorities' Response to the Assessment}

\section{ICP 1: Objectives, powers and responsibilities of the supervisor}

48. Given its recent implementation the NBB finds it's early to conduct a thorough review of the Twin Peaks structure. However, any potential gaps, duplication or coordination issues will be promptly dealt with when they appear.

49. The NBB agrees that an explicit legal basis or principle based approach would be more comfortable, but the NBB is convinced that article 14bis, § 4 Insurance Law could for some limited prudential issues address such lack of an explicit legal basis.

\section{ICP 2: Supervisor}

50. The NBB agrees that there is an inconsistency between the immediate execution possibility for banking and insurance recovery measures in case of an appeal and will rectify this situation via an amendment of the NBB Organic Law.

51. The NBB will reconsider the adequacy of the supervisory resources in order to achieve the appropriate supervisory intensity and effectiveness in the course of 2013.

\section{ICP 5: Suitability of Persons}

52. The NBB is in the process of revising the fit and proper regulation and is currently holding a public consultation on the new proposal. The adoption of the new regulation is planned in the course of 2013.

\section{ICP 7: Corporate Governance}

53. The NBB agrees with all recommendations on corporate governance and is planning to incorporate these when revising the governance requirements in the second half of 2013.

\section{ICP 9: Supervisory Review and Reporting}


54. The NBB continues the development and refinement of the scorecarding approach which should allow for the establishment of a baseline supervisory program and a more precise estimation of required resources. The NBB is planning to increase its technical capacity in particular areas by recruiting additional staff (e.g. actuaries).

55. The NBB will consider the establishment of internal policies for inspecting outsourced functions when updating the methodology and work plan of the audit team.

56. The NBB will reflect on how the contributions of external auditors and actuaries can be assessed on their effectiveness within the context of their role under Solvency II. In this regard, discussions have been initiated with the professional organizations.

\section{ICP 14: Valuation}

57. The NBB is currently revising the Flashing Light approach including the exemption file method in order to better monitor the adequacy of technical provisions, in particular for life insurers' legacy portfolios with high guarantees. The revised Flashing Light approach will be implemented in the second half of 2013.

58. Next to this, the NBB will seriously consider the outcome of European Insurance and Occupational Pensions Authority's (EIOPA) decisions to advance the implementation of some parts of the Solvency II framework.

\section{ICP 16: Enterprise Risk Management for Solvency Purposes}

59. The implementation of ORSA is part of the interim guidelines, which are currently prepared by EIOPA to advance the implementation of Solvency II. The NBB will seriously consider the outcome of EIOPA's decisions to advance the implementation of some parts of the Solvency II framework including ORSA.

\section{ICP 17: Capital Adequacy}

60. The NBB is reflecting on different measures to strengthen the solvency framework including an adaptation of the Flashing Light approach, a revision of the profit sharing mechanism and alternative ways to decrease the maximum guaranteed interest rate.

61. The NBB participates in EIOPA working groups to improve the quality of the calculation of the Solvency II market consistent balance sheet and capital requirements. In this regard, the NBB has recently launched an impact assessment to test proposed measures for products with long term guarantees.

62. In order to have a more accurate view on the solvency position and risk exposures of insurers, the NBB is planning to conduct an EIOPA-led stress test in the second half of 2013. The NBB will also continue the execution of periodic vulnerabilities analyses to monitor the evolution of life insurers' legacy portfolios with high guarantees. 
BELGIUM

\section{ICP 20: Public Disclosure}

63. The NBB is planning to introduce higher disclosure requirements under Solvency II. 


\title{
DETAILED PRINCIPLE-BY-PRINCIPLE ASSESSMENT
}

\author{
Table 12: Detailed Assessment of Observance of the ICPs
}

\begin{tabular}{|c|c|}
\hline ICP 1 & $\begin{array}{l}\text { Objectives, Powers and Responsibilities of the Supervisor } \\
\text { The authority (or authorities) responsible for insurance supervision and the objectives of } \\
\text { insurance supervision are clearly defined. }\end{array}$ \\
\hline Description & 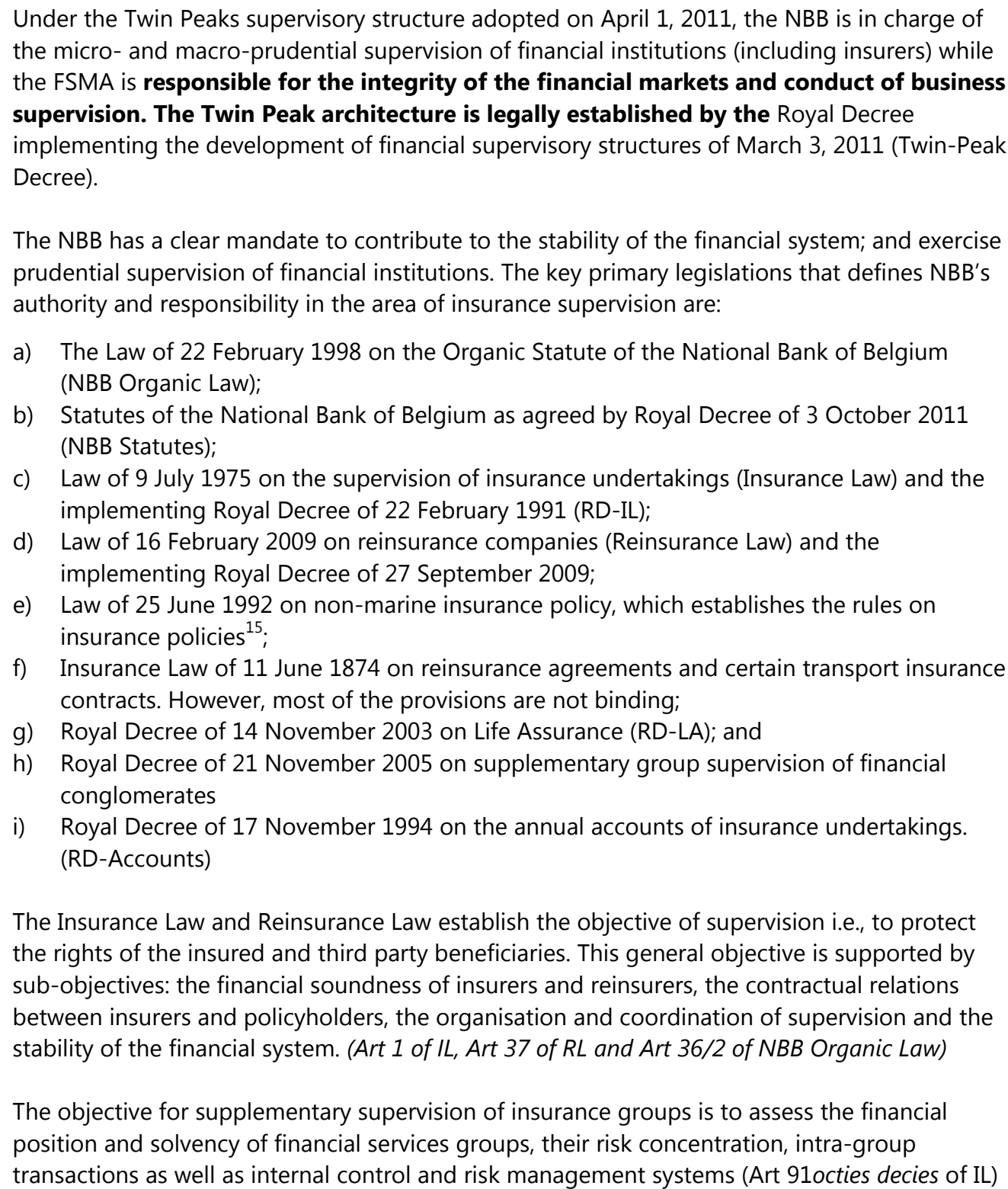 \\
\hline
\end{tabular}

\footnotetext{
${ }^{15}$ Fire insurance, liability insurance, legal expenses insurance, life assurance, etc.
} 
The NBB may establish legally binding regulations supplementing the legal or regulatory provisions on points of a technical nature. The NBB's regulations are subject to approval by the King via Royal Decree. The King may also amend the NBB's regulations or establish rules via Royal Decree (if the NBB has not done so). Amendments to the NBB Statutes require the approval of the King via Royal Decree. (Art 12bis and 36, NBB Organic Law)

However, the scope of the NBB's regulatory power is confined to the adoption of regulations "to supplement the relevant laws or regulations concerning technical aspects." Thus, the NBB legal authority to issue secondary regulations is generally limited to issues that are specifically prescribed in the primary law. In the absence of any specific reference, the NBB has to request the government to effect legislative amendments to address an emerging supervisory concern even though it may be covered in the law at a conceptual level. It is then for the government to decide whether to make the necessary changes in accordance with its own priorities. This generally prescriptive approach adopted for the NBB's rule making power may constrain the NBB's supervisory discretion and/or timely intervention. For example, the NBB would be unable to issue legally enforceable rules to extend the fit and proper requirements to Key Persons in Control Function without changing the law, a regulatory gap noted in ICP $5 .{ }^{16}$ (Art 12bis and 36, NBB Organic Law)

The NBB issues circulars to inform supervised institutions of its supervisory expectations and how it interprets the applicable law and how the NBB will apply the regulations in specific cases. Thus, without being hard law as such, circulars could be considered as legally binding insofar as they elaborate legal principles. The principle of good administration implies that the NBB must respect its circulars and the NBB is expected to explain any deviations from its circulars.

The NBB is adequately empowered to: obtain any necessary information for supervision; conduct on-site inspections; and impose corrective and preventive measures as well as sanctions as outlined in ICPs 9 to ICP 11. (Art $21 \& 26$ of IL, Art $37 \& 71$ et seq. of RL and Art $36 / 19$ of NBB Organic Law)

The FSMA strives to ensure the honest and equitable treatment of financial consumers by insurers and intermediaries. Its competences are: 1 ) supervision of the financial markets and listed companies; 2) supervision of compliance with rules of conduct; 3) supervision of financial products; 4) supervision of financial service providers and intermediaries; 5) supervision of supplementary pensions; and 6) contribution to improving financial education of the public.

The key primary legislations that defines FSMA's authority and responsibility in respect of conduct of business supervision for the insurance sector are:

- Royal Decree of 5 April 2011 on the FSMA's Supervisory Board;

- Royal Decree of 28 April 2011 on the FSMA's Management Committee;

- The Law of 2 August 2002 on the supervision of the financial sector and on financial services (Supervision Law);

\footnotetext{
${ }^{16}$ The NBB has interpreted that Article $14 b i s \S 4$ of the Insurance Law may be used to "impose specific requirements on an insurance undertaking that could inter alia go against the suitability of its organizational structure," including extending the scope of the fit and proper requirements. Article 14bis $\$ 4$ states: "The [Bank] may, without prejudice to the provisions of $\S \S 1,2$ and 3 , specify what is meant by an appropriate management structure, appropriate internal control, an appropriate independent internal audit function, [an appropriate risk management function and, on the advice of the FSMA, an appropriate independent compliance function]."
} 


\begin{tabular}{|c|c|}
\hline & $\begin{array}{l}\text { The Law on non-life insurance contract; } \\
\text { Certain non-prudential provisions of the Insurance Law; } \\
\text { The Company Law; and } \\
\text { The Law of } 27 \text { March } 1995 \text { on insurance intermediation and distribution. } \\
\text { There is no direct conflict between the relevant insurance legislations and the supervisors' } \\
\text { objectives for supervision. Both the NBB and the FSMA do not have development of financial } \\
\text { markets as their objectives. } \\
\text { While not unique to the Twin Peaks structure in Belgium, there could be tension between the } \\
\text { objectives for prudential and conduct-of-business (CoB) supervision. For example, while a } \\
\text { liquidity swap may be deemed to pose no direct/immediate financial risk on insurers, there } \\
\text { may be implications for the protection of policyholders if assets covering technical provisions } \\
\text { are less liquid or more risky. Similarly, it is generally recognised that systemic CoB issues may } \\
\text { have prudential implications for insurers. Given the recent introduction of the Twin Peaks } \\
\text { structure, regular reviews of the practical implementation issues such as communication and } \\
\text { coordination between the NBB and the FSMA is helpful to fulfil the overall objectives of } \\
\text { insurance supervision and achieve synergy from the separation of roles. }\end{array}$ \\
\hline Assessment & Largely observed \\
\hline Comments & $\begin{array}{l}\text { The responsibilities for insurance supervision in Belgium are clearly defined under the Twin } \\
\text { Peak supervisory structure, which has been implemented for less than two years. The NBB and } \\
\text { the FSMA have clear mandates under the Twin Peaks structure, which also enhances checks- } \\
\text { and-balances. The objectives of the supervision of insurers and reinsurer are defined in the } \\
\text { primary legislations. The NBB may establish enforceable rules within the parameters } \\
\text { specifically prescribed in the primary law, subject to the approval of the King or a Minister. } \\
\text { The authorities are advised to: } \\
\text { c) Conduct regular reviews of the practical implementation of the Twin Peaks structure, to } \\
\text { identify and assess any potential gaps, duplication or coordination issues to ensure that } \\
\text { supervisory objectives for the insurance sector are effectively achieved; and } \\
\text { d) Consider a more principles-based approach in delegating legal authority to the NBB to } \\
\text { issue enforceable rules. }\end{array}$ \\
\hline ICP 2 & $\begin{array}{l}\text { Supervisor } \\
\text { The supervisor, in the exercise of its functions and powers: } \\
\text { - is operationally independent, accountable and transparent; } \\
\text { - protects confidential information; } \\
\text { - has appropriate legal protection; } \\
\text { - has adequate resources; and } \\
\text { meets high professional standards. }\end{array}$ \\
\hline Description & $\begin{array}{l}\text { Governance } \\
\text { The NBB is a public institution governed by: } \\
\text { a) Title VIII of Part Three of the Treaty on the Functioning of the European Union; } \\
\text { b) The Protocol on the Statute of the ESCB and of the ECB } \\
\text { c) The NBB Organic Law; }\end{array}$ \\
\hline
\end{tabular}



d) The NBB Statutes;
e) Certain legal provisions relating to public limited liability companies ${ }^{17}$ in respect of matters not covered by a) to d) above;
f) The NBB's Corporate Governance Charter (CGC).

The NBB is listed on the Brussels Stock Exchange, with a share capital of $€ 10$ million. The Belgian government holds 50 percent of the voting rights (200,000 shares) and the remaining shares are held by the public. ${ }^{18}$ As the NBB does not have profit making as its main object, it has a special legal status and organic rules which distinguish it from other public limited liability companies. As a member of the ESCB, the NBB is subject to special accounting rules and special status regarding the information disclosure obligations. In addition, certain provisions of the Belgian Corporate Governance Code do not apply e.g., appointment and dismissal of Board members.

The powers of the general meeting of shareholders are limited to the: election of the Regents and Censors; appointment of the external auditor; endorsing the annual accounts/reports; and amending the NBB Statutes on the proposal of the Council of Regency (where it does not have the power to do so).

The governance structure of the NBB comprises:

a) The Governor directs the NBB and presides over the Board of Directors (Board) and the Council of Regency (Council); (Art 18, NBB Organic Law)

b) The NBB Board is responsible for the administration and management of the NBB, issues the NBB regulations and decides on the NBB's policy direction. The Board also appoints and dismisses members of staff and determines their remuneration. Currently, the Board comprises eight members, in addition, there are two special representatives advising on prudential supervision (but who are not Board members); (Art 19, NBB Organic Law and Art 29 of NBB Statutes)

c) The Council has the authority to: amend the NBB Statutes to conform to the NBB Organic Law and the international obligations which are binding on Belgium; and establish the Code of Conduct for NBB directors and staff. It exchanges views on general issues relating to the NBB, including supervisory policies and international regulatory developments. However, it does not intervene at the operational level. The Council comprises the Governor, the directors and ten Regents, elected by the General Meeting. Dividend distribution ${ }^{19}$ by the NBB is entrusted to the Council, who is responsible for balancing the public interests against the interests of the shareholders of NBB. (Art 20, 31 and 32, NBB Organic Law)

d) The Board of Censors supervises the preparation and implementation of the NBB budget and serves as the Audit Committee of the NBB. The Censors are elected by the general meeting of shareholders for a renewable term of three years. It comprises 10 members, of

\footnotetext{
${ }^{17}$ When the NBB was set up in 1850, the legislature gave it the form of a public limited liability company. The private banks, which had the right to issue banknotes, owned the capital of the NBB. The shares were later listed on the stock exchange.

${ }^{18}$ Except for the shares owned by the State, the NBB does not know of any shareholder with 5 percent or more of the voting rights.

${ }^{19}$ In execution of article 32 of the NBB Organic Law the Council of Regency determines the policy with regard to reserves and dividends.
} 
which one must be independent. (Art 21, NBB Organic Law)

e) The Sanctions Committee, which was not yet operational at the time of assessment. It conducts hearings and pronounces the imposition of administrative fines and penalties on supervised entities (ICP11).

In its role as the Audit Committee, the Board of Censors monitors: a) the financial reporting process; $b$ ) the effectiveness of the internal control, risk management systems and internal audit; $c$ ) the statutory audit of the annual accounts; d) the independence of the statutory auditor. (Art 21 bis, NBB Organic Law and Art 32 bis of the NBB Statute)

The Internal Audit Service of the NBB has the following mandates: a) raising awareness of and independently appraise the enterprise risk management in the NBB; b) provide opinion on and recommendations for improving the internal controls; and provide assistance where necessary in implementing these measures. It does not have direct operational responsibility and reports to the NBB Board. (CGC 2.5)

Prior to the implementation of the Twin Peaks structure, two internal audits were conducted to identify risks arising from the transfer of prudential supervision from the CBFA to the NBB and propose mitigating measures. There was no internal audit on the NBB's prudential supervision after the transfer to allow more time to implement the new supervisory structure. Going forward, the Internal Audit Service plans to conduct risk-based internal audits based on risk assessments of the NBB's statutory functions, including supervisory activities. The current resource level of the Internal Audit Service is inadequate for effective quality assurance of the NBB's supervisory activities.

The NBB submits an annual ECB report and a yearly report on its supervisory activities (its annual report) to the Chamber of Representatives and the Senate. The Governor may be heard by the competent committees of the Chamber of Representatives and of the Senate. (Art 28, NBB Organic Law and CGC 4.3)

The NBB has not defined "emergency" or "significant issues" nor the related internal policies and procedures to deal with these events. The NBB Statutes foresee that the Governor decides on the fact whether or not a specific situation is to be considered as an "emergency" situation, and whether to convene the NBB Board via written or teleconference procedure. The NBB considered that its operational teams have sufficient expertise and are sufficiently conscious to identify a "significant issue" or an "urgency situation" correctly. If a member of the operational services would detect a significant issue or emergency situation he would immediately inform its head of service, who will in its turn directly contact its respective Director and the Governor. (Art 19, NBB Organic Law and Art 29.7 of NBB Statute)

The FSMA is an autonomous public institution established by law. It carries out tasks in the general interest entrusted to it by Parliament. It is governed by:

a) A Supervisory Board that oversees the operations and financing of the FSMA as well as advises on priorities and the implementation of supervisory policies; and

b) A Management Committee that take decisions and measures necessary to carry out the FSMA's supervisory mandate. The Chairman of the Management Committee is the head of the FSMA. All decisions of the Management Committee are collegial in nature. Each member of the Management Committee is responsible for overseeing specific services.

The Audit Committee of the FSMA reports to the Supervisory Board and consists of three members selected from the Board who may not have holdings nor hold a position in any 
supervised entities, or in a professional association representing the supervised entities. The Committee takes cognizance of the internal audit reports and of the response by the Management Committee; examines the draft budget and the financial statements of the FSMA before these are approved by the Board.

\section{Appointment and Dismissal}

The NBB Board is composed of the Governor and five to seven directors. The Governor is appointed by the King for a renewable term of five years. The other directors are appointed by the King, on the proposal of the Council, for a renewable term of six years.

Both the Governor and the directors may be removed from office only if they have been guilty of serious misconduct or if they no longer fulfill the conditions required to perform their duties. The Governor may appeal to the Court of Justice of the EU against a decision of removal while Board members may appeal to the Council of State. These limited grounds for dismissal and the appeal process helps to preserve the independence of the NBB.(Art 23, NBB Organic Law and Art 14.2 of the Statutes of the ESCB)

There is an established policy on the composition of the NBB Board in terms of diversity of experience and skill set. Given the expanded mandate of the NBB in recent years, the Council has addressed the diversity issue in the Remuneration and Appointments Committee Regulations.

The Regents and Censors are elected for a three-year renewable term by the General Meeting. Five regents are chosen on the proposal of labor organizations, industry, commerce and agricultural organizations and from small firms and traders. Five Regents are to be proposed by the Minister of Finance (Minister). The Censors are chosen from among persons with special qualifications in supervision, accounting and financial expertise. (Art 23, NBB Organic Law and Art $35 \& 36$ of the NBB Statute)

Members of the Legislative Chambers, the European Parliament, the Councils of the Communities and the Regions, persons who hold the position of minister or secretary of state or of member (and their staff members) of the Government of a Community or Region may not hold the office of governor, vice-governor, Board member, member of the Sanctions Committee, Regent or Censor. The governor, the vice-governor and Board members may not hold any office in a commercial company or in any public body that carries on an industrial, commercial or financial activity. The Regents and the majority of Censors may not be a member of the administrative, management or supervisory bodies of NBB-supervised institutions nor may they perform management duties in such institutions. (Art $25 \& 26$, NBB Organic Law and Art 37 of the NBB Statute)

The members of the FSMA's Supervisory Board and Management Committee are appointed by Royal Decree for a period of six years.

It is not explicitly foreseen that the reasons for dismissal of the Governor or Board members of the NBB are publicly disclosed. Similarly, reasons for removing the members of the governing bodies of the FSMA need not be disclosed.

The NBB considers that transparency on the dismissal of the Governor or NBB Board members is provided under Belgian administrative law. This is because all administrative acts (such as the dismissal of the Governor) must be motivated. This means that the dismissal decision (in practice a Royal Decree published in the Belgian Official Gazette) have to clearly identify the factual and legal elements on which it is based. Furthermore, in the event that the EU Court of 
Justice decides on any appeal against a dismissal brought by the Governor, the judgment shall be delivered in open court and published in the Official Journal. (Law of 29 July 1991 on Explicit Founding of Administrative Acts),

\section{Independence and Funding}

The NBB has autonomy in its prudential supervision, subject to a limited check through special administrative supervision relating to the enforcement of formal regulations issued by the NBB via Royal Decree.

"Except as regards the tasks and transactions within the domain of the ESCB, the Minister of Finance, through his representative, shall have the right to supervise the Bank's transactions and to oppose the implementation of any measure which is contrary to the law, the Statutes or the interests of the State." "The representative of the Minister of Finance shall, ex officio, attend the meetings of the Council of Regency and the Board of Censors. He shall "...suspend and bring to the attention of the Minister of Finance any decision which is contrary to the law, the Statutes or the interests of the State. If the Minister of Finance has not given a decision within eight days of the suspension, the decision may be implemented." The MoF representative reports to the Minister each year on the performance of his duties. The NBB explained that the phrase "NBB's transactions" refers to non-ESCB book keeping transactions within the competence of the Board of Censors and the Council of Regency (e.g., own portfolio management). For the avoidance of doubt, the authorities are advised to consider carving out the NBB's supervisory activities from the Minister's supervision explicitly, as in the case of its ESCB tasks. The NBB has indicated that it will clarify this issue by amending the NBB Organic Law. (Art 22, NBB Organic Law and Art 41 of the NBB Statute)

The NBB has discretionary power in administering the laws under its purview, in accordance with the general principles of law and with due regard to proportionality and equality. Differences in treatment between supervised entities must be justified by legal or regulatory grounds or within the discretionary power of the NBB. However, the Insurance Law may also provide that the prudential decision exercised by the NBB be subject to agreement by other ministries. A recent example is the rejection of the NBB's prudential decision to lower the maximum interest rate for life policies by the Ministry of Economy and Consumer Affairs.

The costs of supervision incurred by the NBB and the FSMA are funded by regulated entities. The funding scheme: should cover the effective cost of supervision; strives for stability and predictability of the financing burden for supervised institutions; and constitutes a prefinancing system with subsequent regularisation of the paid amounts. Two separate contributions are levied on the insurance sector and the banking/securities sector. For each sector, there are two types of contribution: a) contributions that are part of a global amount for the sector; and b) additional contributions from SIFIs. Contributions from the insurance and banking sectors add up to about 90 percent of the NBB's expenses. At the end of the year, contributions received and receivable are calculated. If the contributions exceed or fall short of the global amount, a correction is made. Excess contribution is refunded while any shortfall would be met by additional contributions. (RD 17 July 2012 (NBB) and RD 17 May 2012 FSMA.)

The Council approves the expenditure budget and the annual accounts prepared by the NBB, assisted by the Budget Committee. The Budget Committee has the power to examine the NBB's budget before it is approved by the Council. It is chaired by one Censor and comprises two regents, one other censor, the representative of the Minister and the director responsible for the Controlling Department (advisory capacity). The NBB has autonomy in the field of salary scales, engaging outside experts, training budget, IT and travel budget. (Art 12 bis $\$ 4$ \&20 NBB Organic Law, Art 30 of NBB Statutes and CGC 2.3.3) 
The FSMA is an autonomous public institution and applies the rules of conduct for financial institutions independently. Its operating costs are funded by supervised entities, via three types of contributions: a) sectoral contributions from entities subject to permanent supervision; b) variable specific contributions to finance the supervision of specific operations or requests e.g., approval of a prospectus, handling notifications, registration and enrolment as well as giving ruling; c) fixed contributions to finance specific costs e.g., the acquisition of the FSMA's registered office. The FSMA's budget must be approved by its Supervisory Board. The FSMA has received additional funding to hire new staff to discharge its responsibilities under the Twin Peaks structure and it has an approved FTE of 311. (Art $44 \& 56$ of SL and Royal Decree of 17 May 2012)

\section{Review and Transparency of Requirements and Procedures}

The NBB and the FSMA publishes the relevant legislation and its supervisory procedures (e.g., the NBB's risk-based supervision approach) as well as circulars and other communications on their websites. These publications promote transparency of the regulatory requirements and supervisory procedures.

The NBB and FSMA regularly review the relevant laws and regulations to take account of evolving market and regulatory developments. As a member of the EU, the authorities also undertake necessary legislative and regulatory amendments to transpose EU Directives into Belgian law.

Proposed laws, regulations and circular letters are typically subject to consultation with the parties concerned. Consultation takes place within the Insurance Commission, which is an advisory committee set up to consider questions raised by the Minister or the FSMA. The Commission comprises 26 permanent members appointed by the King. ${ }^{20}$ The Insurance Commission may also issue advices on its own initiative. The NBB and the FSMA also regularly organizes consultations with the insurance sector to update insurers of upcoming regulatory developments. A recent consultation by the FSMA was on moratorium of complex structured products. (Art 41 of IL)

\section{Information on the Insurance Sector and the Supervisor}

The NBB is legally obliged to publish an annual report on its role and how it discharges its responsibilities. The annual report presents useful information on the financial system including the insurance sector, such as the structure of the insurance market; financial positions of insurers; and regulatory developments in Belgium and the EU. The NBB's Financial Stability Report provides analysis on the potential risks and vulnerabilities in the macroeconomic environment as well as those specific to the insurance sector. These reports are readily accessible on the NBB's website. (Art 28 NBB Organic Law).

While respecting its obligation of professional secrecy, the FSMA communicates as transparently as possible about its decisions and activities, with justifications. This is done through its annual report and its website. The Chairman of the Management Committee can also report to Parliament.

${ }^{20}$ Of the 26 members, 11 members represent supervised entities, 6 members represent the interests of consumers; 3 members represent insurance intermediaries and 6 members with professional experience and qualifications in activities subject to the supervision of the FSMA are nominated by the Minister. 


\section{Appeal Against Supervisory Decisions}

Certain decisions of the NBB, namely its decisions as an administrative authority, e.g., refusal or withdrawal of the authorisation, are subject to a right of appeal with the Council of State. The Council considers only the legality of the decision e.g., it may annul NBB decisions where they are found to be ultra vires. Some appeals may be lodged with the Council of State according to an accelerated procedure, which is subject to specific legal provisions. Appeals against the NBB's decision to impose an administrative fine or penalty may be lodged solely with the Brussels Court of Appeal, which would suspend the NBB's decisions.

Decisions by the NBB to take exceptional recovery measures take effect from the date of notification to the insurer by registered letter or by letter with advice of receipt. The decisions shall take effect against third parties from the date of the publication of the decisions. The NBB may declare its decision to take recovery measures immediately executable notwithstanding an appeal with respect to banks only; but the same power does not apply to insurers. The NBB will rectify this inconsistency via a future amendment of Article 36/22 NBB Organic Law. (Art $26 \S 2$ of IL and Art 36/22 of NBB Organic Law).

Appeals against the decisions taken by the FSMA may be made before the administrative or judicial jurisdictions, as applicable.

\section{Confidentiality}

Except when called upon to give evidence in court in a criminal case, the NBB and members and former members of its organs and its staff members are subject to professional secrecy requirements. Breach of secrecy is subject to criminal penalties. (Art 35, NBB Organic Law and Art $85 \& 458$ of the Penal Code)

Disclosure of confidential information obtained in the course of duties may be made:

a) where the communication is authorized under the relevant laws;

b) to expose criminal offences to the judicial authorities;

c) within the framework of administrative or judicial appeal proceedings against acts or decisions of the NBB and in any other proceedings to which the NBB is a party ;or

d) in abridged or summary form, such that individuals or legal persons cannot be identified.

e) to specified competent authorities - see ICP 3.

(Art 36/13 and 36./14, NBB Organic Law)

The NBB has recently introduced regulations to safeguard confidentiality via the policies on the classification and processing of information. This regulation is applicable to all personnel of the NBB and clearly states how confidential information should be treated. In addition, access to several services where confidential and sensitive information is now restricted to a limited number of staff members.

The Chairman, Management Committee members, Supervisory Board members, Secretary General and the members of staff of the FSMA, as well as persons who have held those positions in the past, are bound by professional secrecy. They may not divulge confidential information revealed to them in the performance of their duties to any person or authority whatsoever. There are a number of exceptions where disclosure is permissible, including sharing of confidential information with domestic and foreign authorities (ICP 3). (Art $74 \& 75$ of $S L$ ) 


\section{Legal Protection}

The NBB and the FSMA, the members of their governing bodies and their staff members shall not bear any civil liability for their decisions, non-intervention, acts or conduct in exercising their supervisory tasks, except for fraud or gross negligence. (Art 12 bis, NBB Organic Law and Art 68 of $S L$ )

In addition, the NBB and its staff are adequately protected against the costs of defending their actions and/or omissions made while discharging their duties in good faith via an insurance agreement covering the costs of defending actions. This insurance agreement was amended in 2011 to cover the NBB staff responsible for prudential supervision. Furthermore, a specific insurance agreement for professional liability with regard to prudential supervision covers the NBB and its personnel even in case of fraud and wilful misconduct.

\section{Supervisory Resources}

Prudential supervision of insurers is conducted by the Insurance Supervision Service of the NBB. In 2011, there were about 36.5 full-time-equivalent (FTE) staff members responsible for supervising 92 direct insurers and 2 reinsurers, allocated as follows: 12.4 FTEs for complex groups, 10.5 FTEs for international companies and 13.6 FTEs for local companies. ${ }^{21}$ There was $^{2}$ also a diverse range of expertise: legal (3), financial (11), actuarial (3) and auditing (11).

While the resources of the Insurance Supervision Service have been increased to around 50 FTEs in 2012, the Assessors are of the opinion that the current level should be strengthened in order to achieve the appropriate supervisory intensity and effectiveness. The considerations are that the Insurance Supervision Service: a) has been allocating disproportionate resources to closely monitor the financial conditions of some insurers in distress since the global financial crisis that began in 2008 and in view of the on-going turbulence in the EU; b) the need to ensure robust supervision of the nine insurance groups, of which six are complex groups. The NBB also has to dedicate resources to serve as an effective group-wide supervisor for two insurance groups; and c) the impending resource-intensive implementation of Solvency II.

The Insurance Supervision Service has been dealing with 10 insurers who have been in the process of being wound-up. The licenses for two of these insurers were revoked by the NBB and the policyholders of one of the insurers may not be fully compensated for their insured benefits. In addition, a number of insurers are subject to enhanced supervision (i.e., beyond the current scope of risk-based supervision and the supervisory intensity varies according to the severity of their conditions) and the NBB is working on a durable solution to deal with this group of insurers. On average, about 10 insurers were subject to enhanced supervision in 2010 and 2011.

Similarly, the FSMA has a significant challenge in supervising a large number of intermediaries. The formulation of a risk-based supervision approach may contribute to better prioritization of supervisory resources. Nonetheless, it is critical that the FSMA has adequate resources for effective on-going supervision instead of the current reactive approach driven primarily by external reporting of breaches or concerns.

${ }^{21}$ Complex Group consists of Belgian entities belonging to a complex group, International Companies are Belgian entities belonging to a foreign group, and local Companies are domestic insurers. 


\section{Integrity and Professionalism}

A Code of Conduct imposes strict rules of behavior on the NBB Board members and staff members, who are expected to maintain the highest standards of professional ethics. They are also subject to the rules on insider trading and market manipulation. (Art $25 \& 25$ bis of the $S L$ and Art 26 of SL).

In particular, the NBB Board and staff members shall observe a respectable attitude and conduct and refrain from any behavior liable to damage the prestige and honor associated with their duties. They shall demonstrate politeness, correctness and fairness in their professional relations. They should show loyalty to the NBB, demonstrate integrity, independence, impartiality and discretion, while respecting high standards of professional ethics. They are expected to avoid any situation liable to give rise to a conflict of interest or appear to do so. (NBB Code of Conduct).

If a member of the NBB Board has, directly or indirectly, an interest relating to proprietary rights which conflicts with a decision or transaction to be decided by the Board, he must inform the other members before the Board deliberates and abstain from the discussions and voting. Similar provisions apply to members of the Council to address potential conflict of interests. (CGC 2.3.2 \& 2.3.3 and NBB Code of Conduct).

Members of the NBB Board and staff members should show restraint in the conduct of all their private financial transactions. They are barred from engaging in transactions exceeding their own financial capacity, particularly if they are of a speculative nature, and also from involvement in any economic or financial transaction liable to obstruct their independence and their impartiality. They may not, directly or indirectly ${ }^{22}$, hold or deal in shares in the NBB or supervised entities (including their parent companies) subject to specified exceptions. (NBB Code of Conduct).

The FSMA's Code of Ethics expects the Chairman, the members of the Management Committee, the Secretary General and its staff members to demonstrate loyalty, integrity, independence, impartiality and discretion without regard to their personal interest. They must subscribe to high standards of professional ethics and avoid any situation posing potential conflicts of interest. In particular, they shall abstain from speculative financial transactions and transactions involving amounts that are disproportionate to their financial standing, distract them from their professional obligations, or influence the objectivity of their assessment or opinion. They are also prohibited from dealing, directly or indirectly, in shares of supervised entities, subject to specific exceptions.

\section{Outsourcing of supervisory functions}

The Twin Peaks Decree authorizes the NBB and the FSMA to outsource supervisory functions to external auditors. The powers of external auditors appointed are broad, including request for document and information, on-site inspections and access to all IT systems. All costs incurred in using the external auditor will be borne by the relevant financial institution. The NBB and the FSMA currently do not outsource any of their supervisory activities.

\footnotetext{
22 "Indirectly" refers to transactions made upon the initiative of or upon the advice of a member of the NBB Board or a staff member by a person with whom he/she has connections. "Connected persons" include spouse or partner, dependent children, a relative (as defined) as well as defined connected legal person.
} 


\begin{tabular}{|c|c|}
\hline Assessment & Partly observed \\
\hline Comments & $\begin{array}{l}\text { The NBB and the FSMA have financial independence in exercising their functions and powers } \\
\text { and they are subject to clear accountability mechanisms. Both the supervisors and their staff } \\
\text { members are legally obliged to safeguard confidential information and have the necessary } \\
\text { legal protection against civil liability except for fraud or gross negligence. } \\
\text { While the NBB and the FSMA have budgetary discretion, there is a need to strengthen their } \\
\text { supervisory resources to achieve appropriate supervisory intensity and effectiveness. There are } \\
\text { explicit procedures for the appointment and dismissal of the members of the governing } \\
\text { bodies of the NBB and the FSMA, and the Belgian Administrative Law provides for } \\
\text { transparency of the reasons for their dismissal. There is an established policy on the } \\
\text { composition of the NBB Board in terms of diversity of experience and skill set. The lack of } \\
\text { internal policy and procedure to ensure prompt escalation of significant events and the lack of } \\
\text { authority for the NBB to declare its decisions to take recovery measures as immediately } \\
\text { executable may hinder timely intervention by the NBB. There is scope for strengthening the } \\
\text { resources of the Internal Audit Service to provide quality assurance on the integrity of } \\
\text { supervisory activities of the NBB. } \\
\text { The authorities are advised to: } \\
\text { a) Rectify the NBB Organic Law to enable the NBB to declare its decisions to take recovery } \\
\text { measures with respect to insurers as immediately executable, notwithstanding an appeal; } \\
\text { b) Ensure that the NBB and FSMA have adequate supervisory resources to achieve the } \\
\text { appropriate supervisory intensity and effectiveness, including a baseline supervisory } \\
\text { program (ICP 9); } \\
\text { c) Consider clarifying that the scope and circumstances for Minister's supervision of the } \\
\text { NBB's "transactions" does not cover the its supervisory activities; } \\
\text { d) Establish clear policies, procedures and decision making lines to ensure prompt escalation } \\
\text { of significant issues to appropriate levels within the NBB as well as in cases of emergency; } \\
\text { and } \\
\text { e) Review the adequacy of resources of the Internal Audit Service of the NBB to provide } \\
\text { assurance on the integrity of its supervisory activities. }\end{array}$ \\
\hline ICP 3 & $\begin{array}{l}\text { Information Exchange and Confidentiality Requirements } \\
\text { The supervisor exchanges information with other relevant supervisors and authorities subject } \\
\text { to confidentiality, purpose and use requirements. }\end{array}$ \\
\hline Description & $\begin{array}{l}\text { Information obtained by the NBB in the performance of its duties is subject to professional } \\
\text { secrecy protections. The NBB Organic Law sets the general framework for the exchange of } \\
\text { information. (Art } 35 \text { and Arts 36/13 to 36/18, NBB Organic Law) } \\
\text { Specifically for the insurance sector, the NBB is empowered to share confidential information } \\
\text { with specified recipients: competent authorities of the EU and other third countries for the } \\
\text { purpose of prudential supervision or financial stability; the FSMA; authorities and legal } \\
\text { representatives involved in bankruptcy or composition proceedings of supervised entities; } \\
\text { external auditors, independent actuaries (and their professional bodies), and competition } \\
\text { authorities in the EU. (Art 36/13 \& 36/14, NBB Organic Law) }\end{array}$ \\
\hline
\end{tabular}


The NBB "may"23 cooperate with foreign authorities that exercise prudential supervision or have a financial stability mandate, including the conclusion of mutual cooperation and coordination agreements. The information exchanged in this context is covered by professional secrecy obligation. In forwarding information received from cooperating authorities, the NBB may specify that the information cannot be disclosed without its express consent or can only be disclosed for purposes for which it has given its agreement. The NBB must also respect any restrictions that may be set out by the foreign authority. (Art 36/16 \& 36/17, NBB Organic Law)

The conditions for cross-border activities and the exchange of information between EU supervisors under the EU life and non-life Directives have been transposed into the Insurance Law. (Art 49 to 78 of IL).

The Insurance Law is silent on whether the existence of an agreement or understanding on information exchange is a prerequisite for information exchange.

In practice, the NBB takes into account the following in deciding whether and to what extent to fulfil a request for information: the nature of the requested information; the ability and willingness of the recipient supervisor to maintain the confidentiality of any information exchanged; and the use to which the information will be put. There is no specific obligation to requests for information in writing.

The NBB may refuse to follow up a request for information, investigation, on-site verification or monitoring if: a) doing so may threaten Belgium's sovereignty, security or public order; b) legal proceedings have already been initiated for the same charges against the same persons in Belgium; or c) these persons have already been tried irrevocably for the same charges in Belgium. In such cases, it shall inform the requesting authority and may provide it with information on the proceedings or judgment. (Art 36/17, NBB Organic Law)

There is no explicit provision authorizing the NBB to inform other involved supervisors of an insurance group in advance of taking any action that might reasonably be considered to affect entities under their purview. Nonetheless, this issue is largely addressed in the coordination arrangements adopted by supervisory colleges, in which the NBB is a member (ICP 25). In addition, the NBB Organic Law does not differentiate between prior or post information sharing, but encompasses both. Prior info sharing is considered part of an efficient cooperation process and the only restriction is that confidential information may only be used for supervisory purposes and that the receiver is bound by a similar professional secrecy.

The collaboration tool ${ }^{24}$ used in the supervisory colleges that the NBB is a member of facilitates timely exchange of pertinent information between the college members and participants. Members of the colleges publish and update a list of all email addresses and persons in charge in the collaboration tool. However, college participants who are not members of the EU or have not signed the IAIS Multilateral MoU do not have access to all information available on the collaboration tool.

The Helsinki and Siena Protocols or the draft Solvency II Directive do not require reciprocity for

\footnotetext{
${ }^{23}$ There is no legal obligation to do so as the communication of confidential information is an exception to the professional secrecy.

${ }^{24}$ This is a security tool used by supervisory colleges to exchange information, on a quarterly or annual basis or in case of major change.
} 
information exchange. As such, the NBB is able to share information without requiring strict reciprocity with EU members. With respect to supervisors outside of the EEA, the exchange of information may be extended on a reciprocal basis as there is no guarantee on the level of confidentiality requirements in the non-EEA states. The NBB may conclude cooperation agreements with these non-EEA supervisors. (Art 91septies decies of IL)

Confidential information can only be shared on the condition that the recipients use that information to carry out their tasks and that they are subject to an equivalent obligation of professional secrecy as the NBB. Furthermore, information communicated by an EEA supervisor may be divulged only with the express agreement of that supervisor. (Art 36/14, NBB Organic Law)

The NBB may only use the information that it has received from other authorities or the FSMA for monitoring supervised entities. All its cooperation agreements have a provision stating that the information to be exchanged needs to be "relevant to ensure effective and efficient supervision." Subject to the agreement of the transmitting authority, the NBB may use this information for other purposes or forward to other authorities.

There is no legal obligation for the NBB to share information under the NBB Organic Law ${ }^{25}$, and the NBB Board and staff members cannot be legally compelled (e.g., in a court proceedings) to divulge official secrecy. Nonetheless, the NBB has executed confidentiality agreements with members of the supervisory colleges that it chairs or participate, which provide that: a) before a home or host supervisor discloses any confidential information to a third party, it will request and obtain prior consent from the supervisor who provided the information; $b$ ) in the event that either the home or host supervisor is required by statute or legal process to disclose confidential information, it will, to the extent permitted by law, inform the relevant supervisor about such possible onward sharing. If that supervisor does not consent such disclosure and if possible and appropriate, the disclosing supervisor will take reasonable steps to resist disclosure.

The FSMA may share confidential information with domestic and foreign authorities subject to conditions that the information: is intended to assist the foreign authority in the performance of its functions; and will be subject to an obligation of professional secrecy equivalent to that applicable to the FSMA. In sharing confidential information, the FSMA may indicate that the information may only be divulged with its explicit consent or for the purposes for which it has given its consent. When the FSMA receives information, it must comply with any restrictions that may be imposed by the foreign authority with regard to the possibility of divulging that information.

\section{Twin Peak Arrangements}

In order to ensure the effective, coordinated supervision of insurance companies, the NBB and the FSMA shall conclude a protocol, which shall be published on their respective websites. The protocol shall determine the arrangements for collaboration between the NBB and the FSMA in all cases where the law provides for: notifications; provision of opinion, consultation, exchange of information or any other contact between the two institutions, and in cases where it is necessary for the two institutions to act in concert to ensure the uniform application of the legislation. (Art 37 of IL)

\footnotetext{
${ }^{25}$ For example, Article 35 of NBB Organic Law foresees that members and former members of the NBB organs or its personnel may share such information when being summoned to testify before criminal courts or tribunals.
} 


\begin{tabular}{|c|c|}
\hline & $\begin{array}{l}\text { The proposed protocol between the NBB and the FSMA was still under negotiation at the time } \\
\text { of assessment. The draft protocol recognizes that the Insurance Law generally does not } \\
\text { provide for the practical modalities for the contact points listed. In addition, the protocol seeks } \\
\text { to enhance the consistency and the efficiency of the supervision exercised by both authorities. } \\
\text { The draft protocol envisages: } \\
\text { a) Concertation provided under the law between the NBB and the FSMA e.g., when the NBB } \\
\text { assesses a change in control in insurers, it has to perform its evaluation in concertation } \\
\text { with the FSMA if the proposed acquirer is an investment firm or management company } \\
\text { authorized by the FSMA (Art } 23 \text { bis } \$ 4 \text { of IL); and } \\
\text { b) Cooperation not provided for in the Insurance Law, e.g., the obligation for the FSMA to } \\
\text { notify the NBB when it notices that an insurer is working with an intermediary who is not } \\
\text { registered with the FSMA; and the obligation of both NBB and FSMA to consult one } \\
\text { another upon drafting of a regulation or a circular on a subject falling within or interfering } \\
\text { with the competencies of the other authority. } \\
\text { Where a financial institution commit serious breaches of the rules of conduct, the FSMA shall } \\
\text { inform the NBB of the alleged breach before taking the following measures: a) prohibiting or } \\
\text { suspending (in whole or in part) the activities of the institution concerned; or b) ordering the } \\
\text { replacement of its management. Where such breaches are systematic, the FSMA may request } \\
\text { the NBB to revoke the license of the institution. The NBB may only refuse the request if the } \\
\text { withdrawal is likely to compromise the stability of the financial system and the FSMA may } \\
\text { challenge the NBB's decision before the MoF, who makes a final decision. } \\
\text { The FSMA notifies the NBB on measures that do not concern the revocation of a financial } \\
\text { institution's license and the NBB may oppose such measures only where the measures would } \\
\text { compromise financial stability or result in the suspension or termination of the institution's } \\
\text { activity as a whole. Disagreement between the FSMA and the NBB will be decided by an } \\
\text { arbitration panel, established on a case-by-case basis. The arbitration panel would comprise } \\
\text { bodies) and its decision is binding and not subject to recourse. (Art 36bis of SL) }\end{array}$ \\
\hline Assessment & Observed. \\
\hline Comments & $\begin{array}{l}\text { The framework for information exchange in Belgium is aligned with the relevant EU Directives } \\
\text { and protocols, empowering the NBB to obtain and exchange information with relevant } \\
\text { supervisors and authorities subject to confidentiality, purpose and use requirements. The } \\
\text { existence of an agreement or understanding on information exchange is, generally, not a } \\
\text { prerequisite for information exchange. The NBB may share information with non-EEA } \\
\text { supervisors on a reciprocal basis or pursuant to cooperation agreements. } \\
\text { Internationally, the NBB is signatory to the IAIS Multilateral MoU. The NBB also participates } \\
\text { actively in relevant supervisory colleges, where information exchanges are to be facilitated by } \\
\text { coordination arrangements agreed by the colleges. However, the coordination arrangements } \\
\text { are not yet signed officially pending the implementation of Solvency II. } \\
\text { Domestically, the MoU between the NBB and the FSMA as required under the Insurance Law } \\
\text { was under discussion at the time of assessment. There is also scope for the FSMA and the NBB } \\
\text { to review how best to strengthen supervisory cooperation as they gain experience in } \\
\text { implementing the twin-peaks structure. }\end{array}$ \\
\hline
\end{tabular}




\begin{tabular}{|c|c|}
\hline & $\begin{array}{l}\text { The authorities are advised to expedite the conclusion of the MoU between the NBB and the } \\
\text { FSMA to guide effective cooperation and exchange of information. }\end{array}$ \\
\hline ICP 4 & $\begin{array}{l}\text { Licensing } \\
\text { A legal entity which intends to engage in insurance activities must be licensed before it can } \\
\text { operate within a jurisdiction. The requirements and procedures for licensing must be clear, } \\
\text { objective and public, and be consistently applied. }\end{array}$ \\
\hline Description & 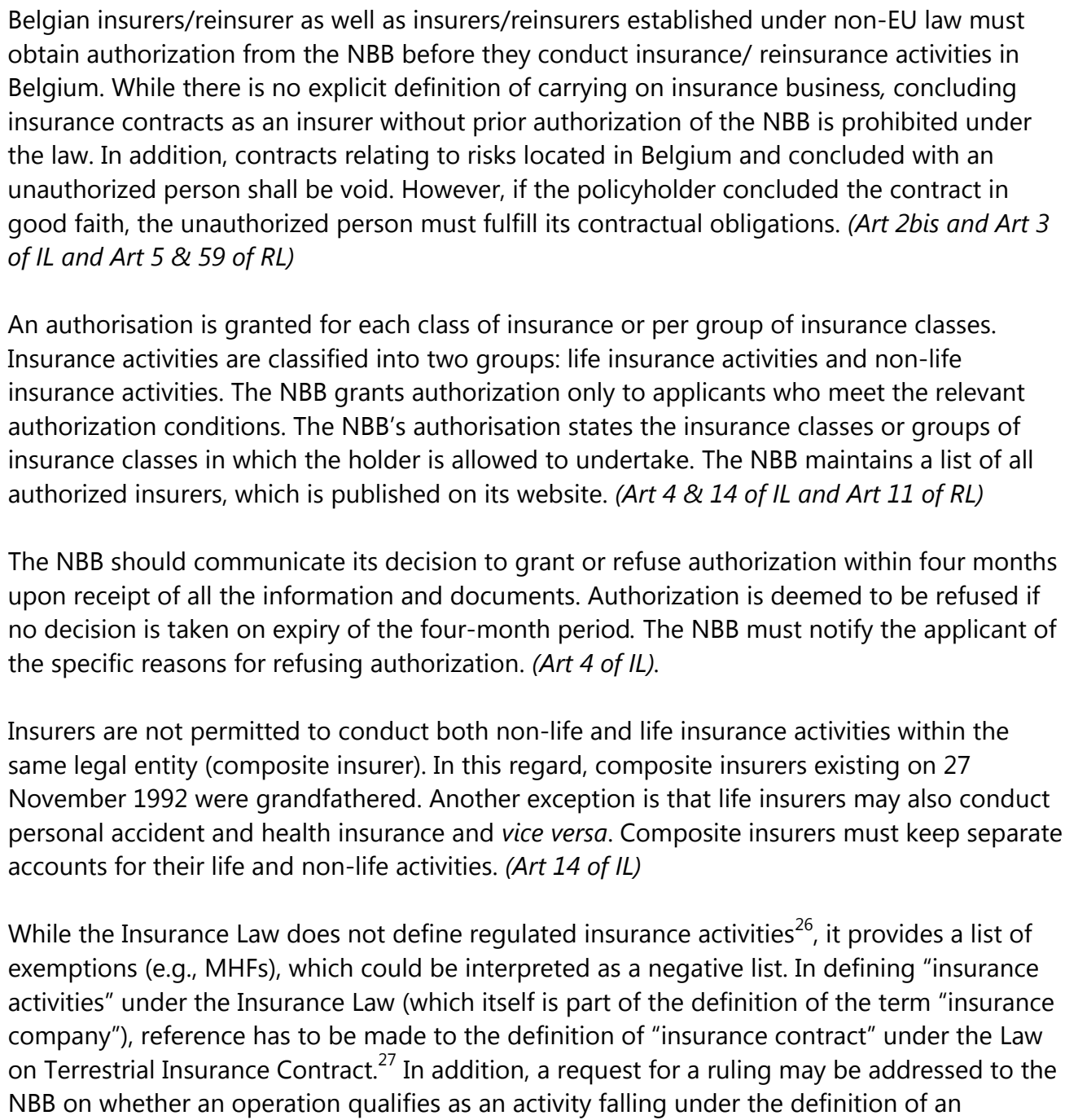 \\
\hline
\end{tabular}

\footnotetext{
${ }^{26}$ The definition of "insurance company" in the Insurance Law only applies in the context of supplementary supervision of insurance groups.

${ }^{27}$ A contract of insurance is defined as "a contract according to which, in return for the payment of a fixed or variable premium, a party, the insurer, commits itself towards another party, the policyholder, to provide the benefit stipulated in the contract in case an uncertain event emerges that, depending on the circumstances, either the insured or the beneficiary does not wish to emerge."
} 
insurance company as laid down in the Insurance Law. The ruling is, in principle, binding on the NBB. ${ }^{28}$ (Art $2 \S 1$, 91bis of IL; Art 1, A, of the Law of 25 June 1992 on Terrestrial Insurance Contract; Art 36/5 of the NBB Organic Law and Art 1, \&1 of the Royal Decree of 23 August 2004)

The Reinsurance Law defines reinsurance companies. The permissible legal forms for insurers/reinsurers are: company limited by shares, cooperative society, mutual insurance association or mutual benefit society (not applicable to reinsurers). Insurers' business activities are restricted to insurance, securities, management of collective pension funds and related activities i.e., they are not allowed to undertake non-financial activities. (Art $4 \& 13$ of $R L$ )

In response to the recommendations arising from the 2006 ICP assessment, the Insurance Law has been amended in 2010 to require the authorization of mutual insurance associations and cooperative societies that limit their activities to the municipality where their registered office is located, or to that municipality and neighboring municipalities. To date, these entities have not complied with the Insurance Law, in anticipation of the entry into force of a Royal Decree that provides partial exemptions. A draft Royal Decree provides for the registration of these entities, which will be subject to regulatory requirements on reinsurance, corporate governance and limits on insurance risks. The NBB has not taken action against this noncompliance on the basis enforcement efforts would be disproportionate to the marginal role played by these institutions in serving the needs of the Belgian insurance market. The total premium income of these institutions is below $€ 20$ million i.e., less than 0.05 percent of the total premium income of the insurance sector in 2011 ( $€ 30$ billion). In addition, these entities will not be captured under Solvency II given their limited scale. Based on the NBB's investigations, all these entities have an annual contribution income below $€ 1$ million. (Art 2 $\S 1$ quater of IL)

An EEA insurer may conduct insurance business in Belgium, either by establishing a branch or under the freedom to provide services, provided that such business is covered by the authorization granted by their home states. The home supervisor must provide the NBB, inter alia, with a certificate attesting the classes of insurance which the insurers has been authorized to offer and that it meets the applicable minimum solvency margin. Non-EEA insurers cannot establish a branch in Belgium unless they comply with specified conditions and they may not sell insurance under the freedom to provide services in Belgium except for specialized risks. Similar requirements apply to reinsurers. To date, no foreign insurer has been granted authorization to pursue insurance activities via a branch in Belgium. (Art 63-73 of IL \& Art 2530 of RD-IL and Art 55-67 of RL)

The licensing conditions include:

a) Fitness of propriety of the applicant's Board members, Senior Management, and significant owners (ICP 5);

b) Capital requirements (Art 15 of IL);

c) Corporate or group structure (Art 14bis of IL);

d) Governance framework including the composition and responsibilities of the Board of directors (Board), Board committees and management team; risk management and internal controls; and

e) Business and financial plans including projected financial statements for the first three financial years.

${ }^{28}$ An example of such a ruling of the former CBFA dated November 2007 on the status of an insurance company can be found on the NBB website http://www.nbb.be/pub/cp/domains/vo/va.htm?l=en 
Upon receipt of a formal and complete application, the NBB acknowledges receipt indicating the date on which the statutory period begins to run. A copy of the application file is sent to the FSMA requesting its opinion in areas within its competence. ${ }^{29}$ The FSMA must give its opinion $^{30}$ within 14 days and no later than two months following receipt of the request. If no opinion is given within the period, the opinion is deemed favorable. If the NBB disregards the FSMA's opinion, it shall record the fact and state the reasons for its decision. The FSMA's opinion shall be attached to the notification of the decision on the application. (Art 8 of IL)

Internally, the NBB appoints a multidisciplinary team to review the application and make recommendation to the NBB Board. The multidisciplinary team evaluates whether the applicant will be in a position to comply with legal requirements and adopt sound financial management, and whether the assumptions for the business plan are realistic. The group and/or organizational structure should not hinder effective supervision. Where necessary, the team may request further clarifications/details or supporting documents. Where the applicant is a subsidiary of another financial institution, the NBB consults the relevant supervisor.

Belgian insurers/reinsurers intending to establish a branch or subsidiary in the EEA must notify the NBB. The NBB may object if it believes the proposal may adversely affect the organization, financial position or supervision of the insurer; or it has reasons to doubt the suitability of the authorized agent or other persons responsible for managing the branch. The NBB must inform the insurer of its objection to establishing a branch within six weeks after receipt of the notification. If there is no objection, the NBB provides the host supervisor in the EEA with a notification, comprising: the scheme of operations; the classes of insurance to be conducted; particulars of the authorized agent; and a certificate of solvency. (Art 22, 50 \& 51 of IL and Art 30-34 of $R L$ )

The NBB must also be notified of any plan to conduct insurance activities via the freedom to provide services abroad. While the NBB can object to an insurer's proposal, it could only intervene a posteriori with respect to a reinsurer. Similarly, When it has no objection, the NBB must send a notification to the host supervisor in the EEA. (Art 57-58 of IL and Art 35 of RL)

While there is no explicit provision empowering the NBB to impose authorisation conditions on insurers, the NBB has indeed imposed authorisation conditions in practice. In contrast, the Reinsurance Law explicitly authorises the NBB to impose authorization conditions. (Art 10 of $R L)$.

The NBB is required to communicate its decision on an application for authorization (granting or refusal) to the applicant. In practice, the authorization process involves an intensive exchange of information between the NBB and the applicant, so that the latter may take the necessary measures or withdraw the application before the final decision is made. (Art 4 of IL and Art 9 of $R L$ )

Over the last few years, the annual number of applications received remained limited:

\footnotetext{
${ }^{29}$ The areas of competence include assessment of the: professional reputation of executive candidates proposed; adequacy of integrity policy as it applies to the rules of conduct; applicant's organization insofar as it affects the fair, honest, and professional treatment of customers; and independence and adequacy of the compliance function. (RD 3 March 2011).

${ }^{30}$ In practice, the FSMA does not provide an "opinion," but informs the NBB if the records of the FSMA contain any negative information concerning the candidate.
} 


\begin{tabular}{|c|c|}
\hline & $\begin{array}{l}\text { approximately one new entrant and eight applications for extension of authorisation to other } \\
\text { classes of insurance by authorised insurers. No authorisations have been granted to non-EEA } \\
\text { applicant. The NBB has not established a policy on inspecting newly authorised insurers to } \\
\text { check that authorisation requirements continues to be met and to verify information } \\
\text { submitted in the application. }\end{array}$ \\
\hline Assessment & Observed. \\
\hline Comments & $\begin{array}{l}\text { Insurance activities within Belgium can only be conducted by authorized insurers/ reinsurers. } \\
\text { The NBB is the licensing authority and the requirements and procedures for obtaining } \\
\text { authorisation are clearly defined, objective and public. While regulated insurance activities is } \\
\text { not defined positively in the Insurance Law, the NBB makes reference to definition of } \\
\text { "insurance contract" under the Law on Terrestrial Insurance Contract and has provided binding } \\
\text { ruling on insurance activities. A multidisciplinary team evaluate applications for authorization } \\
\text { in accordance with established internal procedures, taking account of the FSMA's opinion. } \\
\text { A draft Royal Decree has been prepared to provide partial exemptions to mutual insurance } \\
\text { associations and cooperative societies that limit their activities to the municipality where their } \\
\text { registered office is located, or to that municipality and neighbouring municipalities. The NBB } \\
\text { has not taken action against the non-compliance with the authorisation requirement by } \\
\text { certain mutual insurance associations and cooperative societies on the basis of that their } \\
\text { operations are limited in scale; and these institutions would not fall within the scope of the } \\
\text { draft Royal Decree nor the future Solvency II rules. } \\
\text { The authorities are advised to expedite the finalisation of the draft Royal Decree establishing } \\
\text { proportionate regulatory requirements for local mutual insurance associations and cooperative } \\
\text { societies. }\end{array}$ \\
\hline ICP 5 & $\begin{array}{l}\text { Suitability of Persons } \\
\text { The supervisor requires Board Members, Senior Management, Key Persons in Control } \\
\text { Functions and Significant Owners of an insurer to be and remain suitable to fulfil their } \\
\text { respective roles. }\end{array}$ \\
\hline Description & $\begin{array}{l}\text { The Insurance Law provides that the NBB shall verify whether Senior Management }{ }^{31} \text { and non- } \\
\text { executive directors of insurers have the required professional integrity and appropriate } \\
\text { experience to carry out their functions. Insurers are required to notify the NBB in advance of } \\
\text { any proposal for the appointment, renewal (or non-renewal) or dismissal of Board Members or } \\
\text { Senior Management. (Art. } 90 \text { \& 90bis of IL). } \\
\text { At the time of assessment, the NBB is reviewing its regulations and plans to include Key } \\
\text { Persons in Control Functions }{ }^{32} \text { in the scope of its fit and proper regulation. Another planned } \\
\text { change is to provide more clarity on the criteria for determining "adequate competence and }\end{array}$ \\
\hline
\end{tabular}

\footnotetext{
${ }^{31}$ Senior Management is defined as persons, whether or not members of the Board of directors, whose function implies that they exercise at the highest level a direct and decisive influence on the enterprise's management. Senior Management includes Executive Directors who serve in Board Committees. The NBB may advise insurers on persons who should be considered as Senior Management. (Circular PPB-2006-13-CPB-CPA).
}

${ }^{32}$ Control functions include risk management, compliance, actuarial and internal audit functions. 
experience" (fit) and "good reputation" (proper). Interviews may become a standard procedure for certain persons e.g., chairperson of Boards or Board committees of SIFIs to be conducted by the Governor or NBB Board members. The NBB may also assess the collective fitness of the entire Board.

The fitness and propriety requirement for Significant Owners is discussed in ICP 6.

Insurers must submit the particulars of the candidates proposed to be appointed or renewed as a member of Senior Management to the NBB in prescribed form. The NBB assesses their fitness and propriety and gives its opinion within a reasonable period. If the candidate is proposed for the first time, the NBB shall also consult the FSMA. The FSMA shall inform the NBB of any negative information concerning the candidate within one week following receipt of the request for consultation. (Art 90bis of IL).

The NBB is open to discussing the profile of the proposed candidates with insurers before an official proposal is presented, which helps to screens out candidates that are not suitable.

Information obtained to assess fitness and propriety include: education level, professional experience, employment history and positions held, job description for the proposed appointment, convictions and outstanding investigations (if any), previous prudential assessments, administrative and disciplinary sanctions.

There is currently no explicit requirement for insurers to inform the NBB of any circumstances that may materially adversely affect the suitability of its Board Members, Senior Management and Key Persons in Control Functions. However, if the NBB becomes aware of any issues about their continued suitability (e.g., during onsite inspections, offsite reviews or via automatic notification from judicial authorities), the NBB may perform a re-assessment. The proposed revision of its fit and proper regulation will address this gap.

During the process of renewal of appointment, the NBB will assess whether a Board Member or Senior Management continues to meet suitability requirements and advise the insurer concerned accordingly. Beyond appointment and re-appointment, there is no other formal means for the NBB to ascertain the suitability of such persons on an on-going basis. The new fit and proper regulation will emphasize the continued nature of fit and proper requirements.

Insurers must establish internal policies governing any external positions in other commercial enterprises held by Senior Management or Board Members to minimise conflict of interests and to ensure that they commit adequate attention to discharge their responsibilities in the insurer. (Art 90bis of IL).

External auditors appointed by insurers are subject to the NBB's approval and must meet accreditation criteria established by a joint Decree of the Minister of Finance and Minister of Economy. The accreditation regime seeks to ensure that auditors have the necessary specialized knowledge, attitude and professionalism to conduct insurance audits. Going forward, an accreditation will be valid for six years, after which the auditor concerned has to re-apply. The NBB plans to introduce quality control mechanisms to monitor and assess the contributions of the auditor to the supervisory process.

Where appropriate, the NBB seeks input from other EU supervisors on the suitability of persons. The NBB plans to implement the upcoming EBA Guidelines on Fit and Proper Assessments, to adopt (and even go beyond) the minimum standards at European level which should facilitate cooperation amongst EU supervisors. Exchange of suitability information with non-EU supervisors may be made pursuant to the IAIS multilateral MoU. 


\begin{tabular}{|c|c|}
\hline Assessment & Largely observed. \\
\hline Comments & $\begin{array}{l}\text { The NBB assesses the fitness and propriety of Board Members and Senior Management at the } \\
\text { stage of proposed appointment and re-appointment, based on comprehensive information } \\
\text { and extensive deliberation. It is in the process of revising its fit and proper regulation in line } \\
\text { with international best practices and the key enhancements include: extending the suitability } \\
\text { requirements to Key Persons in Control Functions; requiring notifications by insurers of } \\
\text { circumstances that may materially adversely affect the suitability of persons and greater clarity } \\
\text { on the criteria for fitness and propriety. } \\
\text { The authorities are advised to expedite the revision of the fit and proper regulation. }\end{array}$ \\
\hline ICP 6 & $\begin{array}{l}\text { Changes in Control and Portfolio Transfers } \\
\text { Supervisory approval is required for proposals to acquire significant ownership or an interest } \\
\text { in an insurer that results in that person (legal or natural), directly or indirectly, alone or with an } \\
\text { associate, exercising control over the insurer. The same applies to portfolio transfers or } \\
\text { mergers of insurers. }\end{array}$ \\
\hline Description & $\begin{array}{l}\text { Changes in Control } \\
\text { The Insurance Law and Reinsurance Law define "qualifying holding" as a direct or indirect } \\
\text { holding of } 10 \text { percent or more of the capital or voting rights in an insurer/reinsurer or the } \\
\text { ability to exercise significant influence over the management of an insurer/reinsurer. (Art } 2 \S 6 \text {, } \\
10^{\circ} \text { ter of } I L \text {, Art } 4 \text { of RL) } \\
\text { A (natural or legal) person must give notice and provide relevant information to the NBB on } \\
\text { any proposed acquisition of a qualifying holding in an insurer or increase in the existing } \\
\text { qualifying holding. The notification requirement also applies to: a) changes in holdings to } \\
\text { reach or exceed more than } 20 \text { percent, } 30 \text { percent or } 50 \text { percent stake in an insurer; and b) } \\
\text { reduction in holding resulting in the qualifying holding to fall below the above threshold } \\
\text { levels. If a person fails to notify the NBB or makes an acquisition despite the opposition of the } \\
\text { NBB, the NBB may go to court and the relevant court may take appropriate measures under } \\
\text { the Company Law and declare the decisions of the general assembly partly or totally void. (Art } \\
23 \text { bis of } I L \text {, Art } 24 \text { of } R L \text { and Art } 516 \text { of the Company Law) } \\
\text { The above requirement applies equally to a proposed acquisition by a person outside of } \\
\text { Belgium and the Insurance Law and Reinsurance Law envisage cooperation between the NBB } \\
\text { and foreign supervisors to provide each other with information deemed essential or relevant } \\
\text { for assessment. (Art } 23 b i s \text { of } I L \text { and Art } 24 \text { of } R L \text { ) } \\
\text { In addition, an insurer must inform the NBB if it becomes aware of any acquisitions or } \\
\text { disposals of its securities or shares that that would result in holdings either exceeding or } \\
\text { falling below the above thresholds. Insurer shall also, at least once a year, inform the NBB of } \\
\text { the names of shareholders who, directly or indirectly, possess qualifying holdings and the } \\
\text { percentage held. (Art } 23 \text { bis of } I L \text { and Circular to financial institutions on acquisitions, increases, } \\
\text { reductions and disposals of qualifying holdings) } \\
\text { Any person acquiring } 5 \text { percent or more of the voting rights of an insurer; or disposing interest } \\
\text { resulting in the existing holdings to fall below } 5 \text { percent, should notify the NBB within } 10 \text { days }\end{array}$ \\
\hline
\end{tabular}


after the acquisition/disposal. The same obligation applies for a transfer of shares resulting in the transferee reaching the same threshold. Any person wishing to acquire qualifying holdings in an insurer is encouraged to contact the NBB prior to submitting their notification. (Art 23bis § 7of IL Circular 2009_32 and Communication 2009_31 of 18 November 2009).

The NBB appraises the suitability of a proposed acquirer based on the same criteria that are applicable for assessing application for new authorization. The criteria adopted include: a) the reputation of the proposed acquirer; $b$ ) the reputation and experience of any person who will direct the business of the insurer as a result of the proposed acquisition; c) the proposed acquirer's financial soundness; d) whether the insurer is able to continue to comply with the relevant prudential requirements and whether the resulting group structure hinders effective supervision; and e) assessment of potential risks of money laundering or terrorist financing. The NBB may oppose the proposed acquisition and inform the proposed acquirer in writing. (Art 23bis of IL)

If the NBB has reasons to believe that the influence exercised by a person who possesses a qualifying holding is likely to compromise the sound and prudent management of an insurer, it may: a) suspend the exercise of the voting rights attaching to the shares held by that person; or b) order that person to assign the voting rights within a specified time limit. (Art 24 of IL)

The Insurance Law provides for the conversion of a mutual company to a stock company. The conversion proposal shall be explained in a report to be presented at the general meeting held to pass a resolution on the conversion. The drafts of the reports shall be forwarded to the NBB and the FSMA for comments and prior approval is not required. If the insurer chooses not to take the comments of the NBB/FSMA into account, the NBB/FSMA can require that their comments be transmitted to the general meeting and recorded in the minutes. However, the NBB and the FSMA do not have the legal power to oppose the conversion. In practice, the conversion of mutual company to a stock company has not occurred in Belgium and the NBB would intervene through indirect means, if necessary. (Art. 78 ter and 78 quarter of IL).

\section{Portfolio Transfer}

The transfers of all or a part of the business of an insurer or reinsurer are subject to notice and approval of the NBB. This requirement applies to Belgian insurers and foreign branches of non-EEA insurers.(Art 74-78 of IL and Art 28 of RL)

The transferor must inform the NBB of the reason for the transfer and submit the following information: a copy of the transfer agreement, approval of the transfer by the Board of the insurer, a list of the countries where the transferred risks are situated, the terms of the transfer and the assets and liabilities to be transferred.

The NBB assesses whether the rights of policyholders, insureds and beneficiaries will be preserved after the transfer and whether the transferee satisfies the financial requirements after the transfer. Where necessary, the NBB consults with foreign supervisors.

If a transfer is approved, the NBB publishes its decision in the Belgian Official Gazette. Policyholders have the option of cancelling their contract within 90 days from the date of publication. The transferee insurer does not have the right to change the policy terms and conditions of the transferred policies. (Art 77 \&-78 of IL) 


\begin{tabular}{|c|c|}
\hline Comments & $\begin{array}{l}\text { The Insurance Law defines qualifying holdings and set the thresholds for the acquisition of and } \\
\text { increase/decrease in qualifying holdings, which require the prior approval of the NBB. The } \\
\text { criteria for assessing acquisition proposals are the same as those applicable for initial } \\
\text { authorization applications. Insurers are required to: a) notify the NBB of changes in qualifying } \\
\text { holdings that would result in a person's holdings either to exceed or to fall below the specified } \\
\text { thresholds; and b) submit the names of their Significant Owners annually. Portfolio transfers } \\
\text { are subject to the approval of the NBB, to protect the rights of policyholders, insureds and } \\
\text { beneficiaries. } \\
\text { The NBB and the FSMA do not have the power to approve or oppose the conversion of a } \\
\text { mutual company to a stock company. Nonetheless, they are expected to comment on the } \\
\text { conversion proposal and may intervene through indirect means, if necessary. Such conversion } \\
\text { has been rare in Belgium. } \\
\text { The authorities are advised to consider empowering the NBB and FSMA to approve the } \\
\text { conversion of the mutual companies to stock companies, to better safeguard the interests of } \\
\text { policyholder and beneficiaries. }\end{array}$ \\
\hline ICP 7 & $\begin{array}{l}\text { Corporate Governance } \\
\text { The supervisor requires insurers to establish and implement a corporate governance } \\
\text { framework which provides for sound and prudent management and oversight of the insurer's } \\
\text { business and adequately recognizes and protects the interests of policyholders. }\end{array}$ \\
\hline Description & $\begin{array}{l}\text { The NBB assesses the corporate governance framework of insurers both at the time of } \\
\text { licensing and as part of ongoing supervision. Governance supervision is conducted at both the } \\
\text { solo and group levels and the NBB's assessment is recorded in the Scorecard system (ICP 9). } \\
\text { The Insurance Law requires the governance framework and organisation of an insurer to be } \\
\text { appropriate and tailored to the nature, size, complexity of its operations and risk profile. } \\
\text { Insurers are required to adopt a coherent and transparent organisational structure with } \\
\text { appropriate segregation of functions, and clear delegation of authority and responsibilities. } \\
\text { Insurers must have adequate internal controls and risk management systems (ICP 8). This } \\
\text { forms the legal basis for the cross-sectoral and sectoral corporate governance circulars issued } \\
\text { by the NBB (Art 14bis of IL). } \\
\text { In } 2007, \text { the former CBFA published a cross-sectoral Internal Governance Circular (Cir-IG) to set } \\
\text { out supervisory expectations on financial institutions' sound governance. Cir-IG presents 10 } \\
\text { principles }{ }^{33} \text { to be applied in a proportionate manner that reflect the scale, nature and } \\
\text { complexity of an institution's operations. A comply-or-explain approach is adopted except for } \\
\text { principles that constitute legal obligations under a supervisory law, a decree or regulation. } \\
\text { (Circular PPB-2007-6-CPB-CPA) }\end{array}$ \\
\hline
\end{tabular}

33 1: Qualities required of significant shareholders; 2: Adequate governance structure; 3: Allocating powers and responsibilities; 4: Plurality of managers, collegial decision-making, and distribution of tasks among senior managers; 5: Independent control functions; 6: Qualities required of the company officers; 7: Remuneration policy for company officers; 8: Strategic aims, enterprise values and conflicts of interest policy; 9: Know your structure, know your activities; and 10: Publicity and disclosure. 
There is no explicit legal requirement on the duties of individual directors, except for their general duties under the Company Law i.e., the general duty of care and loyalty. The NBB explained that the Company law in Belgium uses a broad concept for "company interest", which means that the interests of policyholders are automatically included when considering the interests of the insurance company. Belgian case law confirms this broad perspective. The Cir-IG mentions at different instances the interests of policyholders as those in favour of whom decisions of an insurer must be finally taken and assessed. The internal governance rules of the Boards, including a conflict of interest policy may contribute to the directors (and the Board) acting in a manner that does not prejudice the interests of policyholder or the insurer. The Assessors, however, are of the opinion that, in the absence of the explicit duty on individual directors to "act in the best interest of the insurer and policyholders" (per ICP 7.4), it is unclear whether and how directors are expected to balance potentially conflicting interests of different stakeholders who are all encompassed under the "broad perspective." e.g., between parent bank of an insurer and policyholders in a liquidity swap transaction.

The Cir-IG is also applicable to insurance groups. In particular, conflicting interests at the group level should be identified, minimized or managed. Such conflicts could arise: a) because of conflicting activities amongst entities within the group (e.g., operations for own account, asset management, corporate finance); b) intra-group transactions and allocation of funds within the group; $c$ ) between the parent company and subsidiaries or among the subsidiaries, e.g., as regards the allocation of corporate opportunities; and d) group decisions which have a different impact on financial positions across entities e.g., investments/divestments, valuation methods, etc. Transactions with related parties should be effected at arms' length and monitored.

The NBB's position is that the different interests (the group, subsidiaries and the parent) should be balanced and that intra-group transactions should not prejudice the interests of stakeholders of a regulated subsidiary. In particular, an insurer within a group must, inter alia, remain alert to: any group level decision or practice that is in breach of regulatory requirements or prudential rules; be mindful of the impact on sound and prudent management as well as its financial health; and the interests of its own stakeholders including the protection policyholders or investors and the integrity of the market. (Para $85 \& 86$ of CirIG)

In assessing several intra-group liquidity swaps between insurers and their related banks (mainly to check compliance with concentration limits), the NBB also considered whether the insurer concerned was in a position to take autonomous decision i.e., whether it has validated the transaction taking into account its own interest. The NBB checks whether these principles have been applied in practice e.g., through reading the minutes of the Board, the Audit Committee or when approving a strategic decision by a SIFI. The NBB opined that, in larger insurance groups, independent directors at the subsidiary level would have a flagging function in this respect. While the above measures would help to safeguard the interest of the insurer, which may indirectly address the interests of the policyholders, the interests of an insurer and its policyholders may not be fully aligned all the time. In this regard, the Assessors would reiterate that, the duty of insurers' Board and individual directors towards policyholders should be clearly and explicitly articulated to ensure that there is no doubt on their duty to act in the best interest of policyholders and the insurer.

Each institution is required to document, in a governance memorandum, the following: shareholders structure; group structure (where applicable); policies relating to the composition of the governing bodies; governance structure; and integrity policy. The insurers' Board of directors, in consultation with a management committee, should approve the governance memorandum. The memorandum should be updated to reflect significant changes and 
assessed at least once a year. The memorandum and any significant changes should be communicated to the NBB, as inputs for its supervisory assessment. The operational supervision team reviews minutes of the governing bodies or Board committees of the larger insurers as part of ongoing supervision.

Cir-IG recommends the separation of three functions of financial institutions: the management of the enterprise's activity (management function); supervision of management (oversight function); and formulation of strategy and policy (general policy function). The management function is generally entrusted to executive directors who sit on the management committee of the Board (if established) while the supervisory and general policy functions are entrusted to the Board, which should comprise of a majority of non-executive directors. Insurers who do not establish a separate management committee is expected to provide justification. Cir-CG outlines the separation of tasks between the Board and the management committee.

Insurers are expected to adopt policies on: the composition of its governing bodies (and selection criteria to foster diversity of knowledge and experience), criteria on independence of directors and management of conflicts of interest. Where a management committee is established, there should be separation in the roles of the chairman of the Board and chairman of the management committee.

Insurers should assess the effectiveness the governance framework regularly. The conclusions of these assessments and the measures taken to improve governance are to be documented. Cir-CG is silent on the funding and resources of Board of directors to ensure effective oversight.

While there are binding legal obligations on banks regarding remuneration policies and practices, the Circular on Sound Remuneration Policies is not legally binding on insurers. The remuneration policy covers: members of the governing body; members of the management committee; employees who perform key functions or independent control functions; and major risk-taking staff. The Circular reflect the recommendations by the Financial Stability Board, including: alignment between the remuneration policy with risk management profile and practices, balance between fixed and variable elements; use of adequate long term performance criteria; risk adjustments and the use of deferral or claw back; avoidance of conflicts of interest. In practice, insurers that are part of a banking group are subject to the binding remuneration regulation, applied on a group-wide basis. Going forward, Solvency II will incorporate requirements on remuneration policies of insurers.

In the event of bankruptcy, payments made by the insurer to its directors or managers in the form of bonuses or other form of remuneration in the preceding two years shall be invalid. This claw-back does not apply if the Court acknowledges that there was no serious, manifest misconduct by the directors which contributed to the bankruptcy. (Art 90 \& of IL)

The Board of an insurer should verify regularly whether an insurer has proper internal controls to ensure the reliability of financial reporting processes and address key findings by internal and external audits. Insurers who meet certain threshold criteria must establish an audit committee comprising of all non-executives director, of which at least one member must satisfy strict independence criteria. Senior management (or the Management Committee) has the duty to submit an "Internal control report", at least annually, to the Board and the NBB. Senior Management must also state that the prudential returns submitted to the NBB are complete and accurate. The role of the external auditor in the supervisory process is described in ICP 9.

The governance memorandum submitted by an insurer is a confidential document and is not 


\begin{tabular}{|c|c|}
\hline & $\begin{array}{l}\text { published. Cir-IG has a high-level principle that insurers are to "communicate with its } \\
\text { stakeholders about the principles it applies with regard to its governance structure". This } \\
\text { includes information on the shareholders structure and the control structure, as well as the } \\
\text { structure of the group if any; the governance structure and the impact of the group dimension } \\
\text { if any; the financial institution's objectives and enterprise values and its policy guidelines on } \\
\text { conflicts of interest, remuneration structure, etc. }\end{array}$ \\
\hline Assessment & Largely observed. \\
\hline Comments & $\begin{array}{l}\text { Since the last assessment in 2006, the authorities have significantly strengthened the } \\
\text { regulation and supervision of insurers' corporate governance, by adopting legally binding } \\
\text { minimum requirements in the field of governance, supplemented by a comply-or-explain } \\
\text { approach that is supported by detailed supervisory guidance. The NBB's assessment of } \\
\text { insurers' governance practices is a key input in the Scorecard System and in prioritising it risk- } \\
\text { based supervision. The authorities are in the process of updating the Internal Governance } \\
\text { Circular to take account of evolving international best practices. } \\
\text { The corporate governance framework could be enhanced by establishing clearer and explicit } \\
\text { supervisory expectation on: } \\
\text { a) The duties for directors to act in a manner that would not compromise the interests of the } \\
\text { insurer and policyholders, particularly with respect to intra-group transactions; and } \\
\text { b) Adequate powers and resources for the Board of directors to exercise effective oversight. }\end{array}$ \\
\hline ICP 8 & $\begin{array}{l}\text { Risk Management and Internal Controls } \\
\text { The supervisor requires an insurer to have, as part of its overall corporate governance } \\
\text { framework, effective systems of risk management and internal controls, including effective } \\
\text { functions for risk management, compliance, actuarial matters, and internal audit. }\end{array}$ \\
\hline Description & $\begin{array}{l}\text { The legal basis of the regulation on risk management and internal control is Article } 14 \text { bis of } \\
\text { the Insurance Law, complemented by circulars to specify the requirements: } \\
\text { - Circular CBFA_2008_13 of } 5 \text { June } 2008 \text { on risk management requires insurers to have in } \\
\text { place a risk management system comprising strategies, policies and processes to identify, } \\
\text { assess, monitor, manage and report on risks to which they are or could be exposed on an } \\
\text { individual or aggregated level. } \\
\text { Circular PPB-2006-8-CPA of } 23 \text { May } 2006 \text { on internal control system and internal audit } \\
\text { function requires insurers to have in place an adequate and effective internal control } \\
\text { system. } \\
\text { Circular CBFA_2009_26 dd. } 24 \text { June } 2009 \text { specifies the supervisory expectations on the } \\
\text { description and assessment of the internal control system. } \\
\text { Circular CBFA_2009_33 of } 19 \text { November } 2009 \text { on the actuarial function. } \\
\text { Circular PPB/D.255 of } 10 \text { March } 2005 \text { on the compliance function. } \\
\text { Circular CPA-2006-1-CPA on requirements on internal models and asset-liability } \\
\text { management (ALM), and the risk management system (cf. standard } 15.4 \text { and } 15.5 \text { ). } \\
\text { Circular PPB-2006-1-CPA of } 6 \text { February } 2006 \text { describes the requirements of the NBB in } \\
\text { relation to outsourcing. } \\
\text { Article } 14 b i s \text { of the Insurance Law together with the above circulars require insurers to have in } \\
\text { place independent, objective and effective control functions: a risk management function, an } \\
\text { internal audit, a compliance function, and an actuarial function. } \\
\text { Common to all control functions are the regulatory requirements that these functions must be }\end{array}$ \\
\hline
\end{tabular}


sufficiently independent, and are resourced in such a way that they are able to undertake their missions effectively. All control functions are reviewed by the external auditor and the internal control system has to be assessed annually. The scope of the internal audit function covers all control functions except itself.

\section{Requirements on the Risk Management System}

The main risk management requirements are defined in the Circular CBFA_2008_13 of June 5, 2008 (Risk Management in Insurance Companies):

The risk management system is defined to include the strategies, processes and procedures needed to track, manage and report, on a permanent basis, the risks to which insurers are or could be exposed, as well as the interdependence between these risks, at the individual and aggregate levels. Risk management should be fully integrated into the organizational structure of an insurer.

The objective of the system is to identify, evaluate, manage and monitor the risks to which insurers are or could be exposed to. The risk management function is held responsible for the effective implementation of the risk management system.

Sound risk management is required to observe four fundamental principles:

- Involvement of the Board and Senior Management, including the management committee if any;

- An appropriate risk management function;

- Adequate risk management policies;

- Appropriate monitoring and reporting.

Further requirements are then elaborated in 10 principles, which are outlined below.

1. The Board is responsible for defining the general strategies for risk management and to assess the overall objectives of an insurer from a risk perspective. It ensures that Senior Management or the management committee has made the necessary provisions to implement a risk management system and is responsible to regularly monitor the implementation. The Board encourages dialogue with Senior Management and other senior staff on risk exposures.

2. Senior Management is responsible for implementing the directives of the Board consistent with the strategy, comprising a transparent organizational structure with clear responsibilities and delegations of power and documented processes and effective controls. The risk reports submitted to the Board must provide concise and complete information sufficient to assess an insurer's sensitivities to changes in risk factors.

3. An insurer must have a permanent risk management function, covering all risks. If an insurer is sufficiently large or complex, a separate, independent risk management department has to be constituted.

4. The risk management function must be independent of risk taking functions and reports directly to a member of senior management or of the management committee. The status of the risk management function has to be documented, approved by senior management and confirmed by the Board. The risk management function must be able to report directly and at its own initiative to the Chair of the Board or to members of the committee appointed to assist the Board.

5. Senior Management is responsible for ensuring that risk management is conducted by qualified personnel who have experience in technical and actuarial matters commensurate 
with the nature and complexity of the insurer's activities.

6. Risk management principles and techniques must take into account the nature, size and complexity of the business activities.

7. The risk measurement system has to evaluate all risks and rely on realistic assumptions that are explained and justified. Insurers must ensure that all accounting and nonaccounting data are incorporated into the measurement system in a timely manner. The impact of assumptions must be explained, justified, documented and approved by senior management, and reviewed or revised at least annually.

8. Senior Management must establish and impose limits and other practices to keep risks within the limits of tolerances as defined by the Board. If limits are exceeded, this has to be reported promptly to senior management. There should be a policy in place specifying the procedures on limit breaches. The risk management function has to regularly evaluate the methodologies, models and assumptions for measuring and limiting positions. Insurers have to perform an internal evaluation of its risk exposures and solvency at least annually, including the adequacy of its entire policy for managing risk.

9. Insurers must have an adequate information system for maintaining surveillance and reporting their risk exposures on a timely basis to the Board, Senior Management and as necessary to managers of operating departments. The reports must contain at least inventories of the overall exposure, statements demonstrating observance of policies and limits, results of critical tests, summaries of the supervisory conclusions relating to the adequacy and observance of policies and procedures established for risk management and the adequacy of the risk management system.

10. Risk management must be within the scope of internal audit.

\section{The Compliance Function}

Circular PPB/D.255 of 10 March 2005 requires all insurers to have an independent and effective compliance function. Insurers must have an integrity policy covering at least all insurance related laws, money laundering, financing of terrorism, fraud and discrimination. The compliance function is responsible for the implementation of the integrity policy.

Senior Management has to approve the missions, responsibilities, authorities, communication and reporting of the compliance function, which has to be disclosed to all staff. The compliance function should have unlimited access to all staff and needs to be adequately resourced and educated. It has to prepare and submit annually a compliance report detailing its activities.

\section{The Actuarial Function}

Circular CBFA_2009_33 of 19 November 2009 requires insurers to have an effective actuarial function. All insurers must have an actuarial function, which has the actuarial knowledge to issue a report on the prices, retrocession and the amount of technical provisions (TP).

The role of the actuarial function involves:

- Issuing judgment on the technical-actuarial methods used for pricing, technical provisioning, profitability and reinsurance of new or modified products; and

- Providing annually an opinion on the profitability of products, TP and reinsurance and with-profits plans.

The opinion is intended for the insurer's effective management and must also be sent to the NBB. The opinion must be detailed and cover compliance with regulatory requirements and 
technical aspects specified in the Circular.

Senior Management is responsible for making all necessary information available to the actuarial function. If the actuarial function finds that information is not available, Senior Management has to be informed at once. If this situation were to persist, the Board has to be informed and the NBB.

The actuarial function has to be organized in such a way as to avoid conflicts of interests. In particular, persons working for the actuarial function cannot be members of the effective management or a director, an approved auditor, or with the compliance function or with internal audit.

\section{The Internal Audit Function}

Circular PPB-2006-8-CPA of 23 May 2006 requires insurers to have an independent and effective internal audit function to provide management with an independent assurance on the adequacy and effectiveness of the internal control system. The internal audit function has to be independent of all functions that it audits.

The internal audit charter details the responsibilities: position within the insurer, mission, authorities; communication and reporting of the internal audit function and has to be approved by senior management and the Board of Directors.

The internal audit function must have unrestricted access to all people and all information and it can report, on its own initiative, to the Chairman of the Board, members of the audit committee and the external auditor. It needs to have enough qualified resources to enable it to accomplish its missions. The internal audit function can be outsourced.

The internal audit function should submit annually a report on its activities, recommendations and follow up on previous recommendations.

For larger insurance groups, as part of the annual supervisory work plan, a yearly meeting with the chief audit executive is held to discuss the annual audit report, the key activities and the audit work plan for the following year.

\section{Outsourcing}

Circular PPB-2006-1-CPA of 6 February 2006 describes the requirements of the NBB in relation to outsourcing.

Each insurer should have an outsourcing policy that is approved by senior management and the Board. Outsourcing does not transfer the responsibilities of the insurer. The insurer has to take measures to control and manage risks of outsourcing. Insurers are expected to have sufficient knowledge and resources to control and monitor the outsourced activities or functions.

Outsourcing providers have to be chosen based on a detailed analysis of risks, including financial, reputational, operational and technical risks. Insurers have to take measures to be able to change providers or reintegrate outsourced activities in case providers cannot comply with its obligations.

Outsourcing has to be defined by a contract, clearly describing the obligations of both parties and addressing the possibilities of sub-sourcing and associated conditions. 


\begin{tabular}{|c|c|}
\hline & 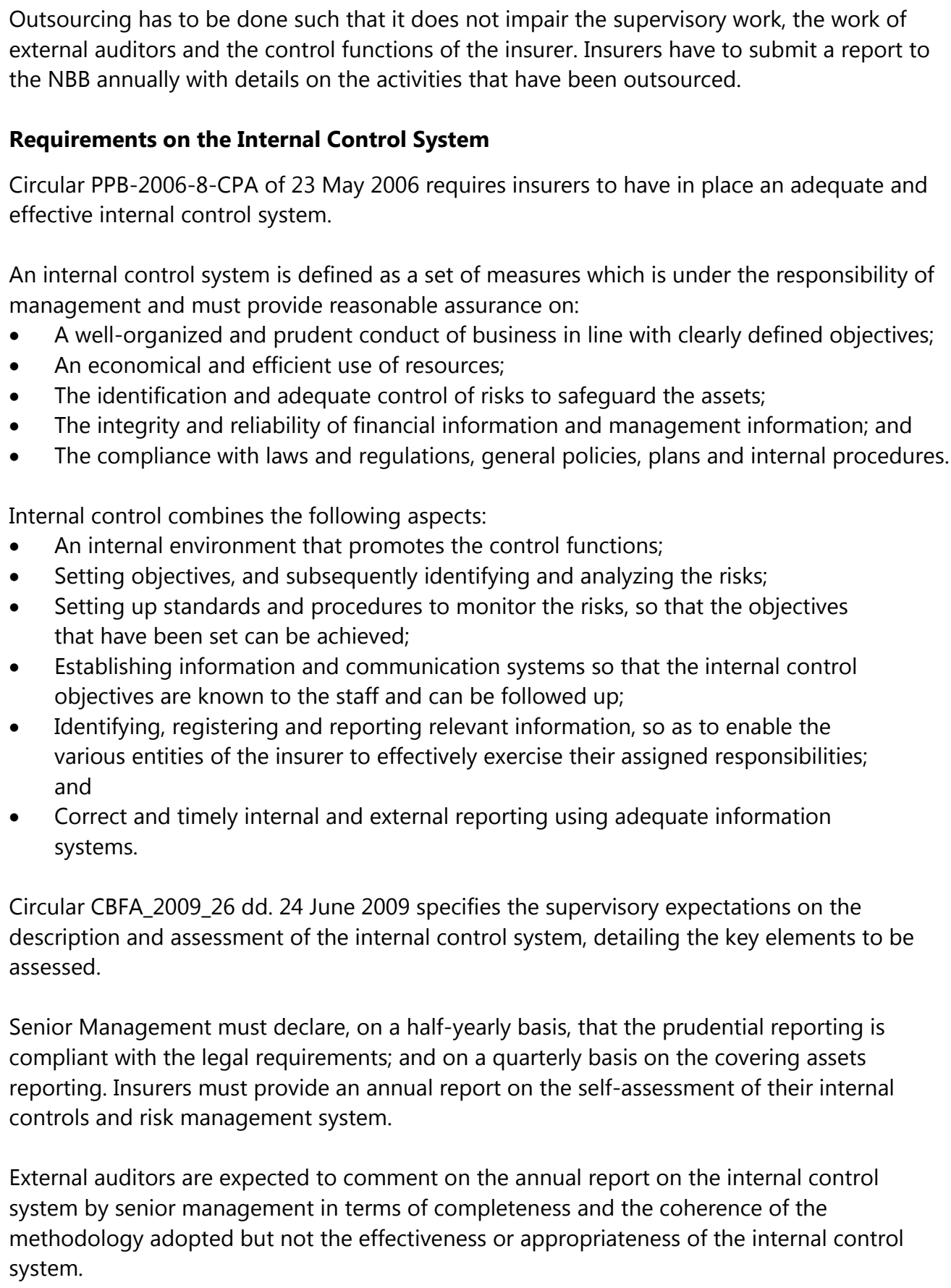 \\
\hline Assessment & Observed. \\
\hline Comments & $\begin{array}{l}\text { The authorities have established sophisticated principles-based risk management and internal } \\
\text { control system requirements. Stronger requirements apply to insurers who are exempted from } \\
\text { the Flashing Light provisions. The accredited external auditors play a substantial role in } \\
\text { reviewing insurers' report to the NBB on their internal control system (refer to ICP 9). }\end{array}$ \\
\hline
\end{tabular}




\begin{tabular}{|c|c|}
\hline ICP 9 & $\begin{array}{l}\text { Supervisory Review and Reporting } \\
\text { The supervisor has an integrated, risk-based system of supervision that uses both off-site } \\
\text { monitoring and onsite inspections to examine the business of each insurer, evaluate its } \\
\text { condition, the quality and effectiveness of its Board and Senior Management and compliance } \\
\text { with legislation and requirements. The supervisor obtains the necessary supervisory } \\
\text { information to conduct effective supervision of insurers and evaluate the insurance market. }\end{array}$ \\
\hline Description & 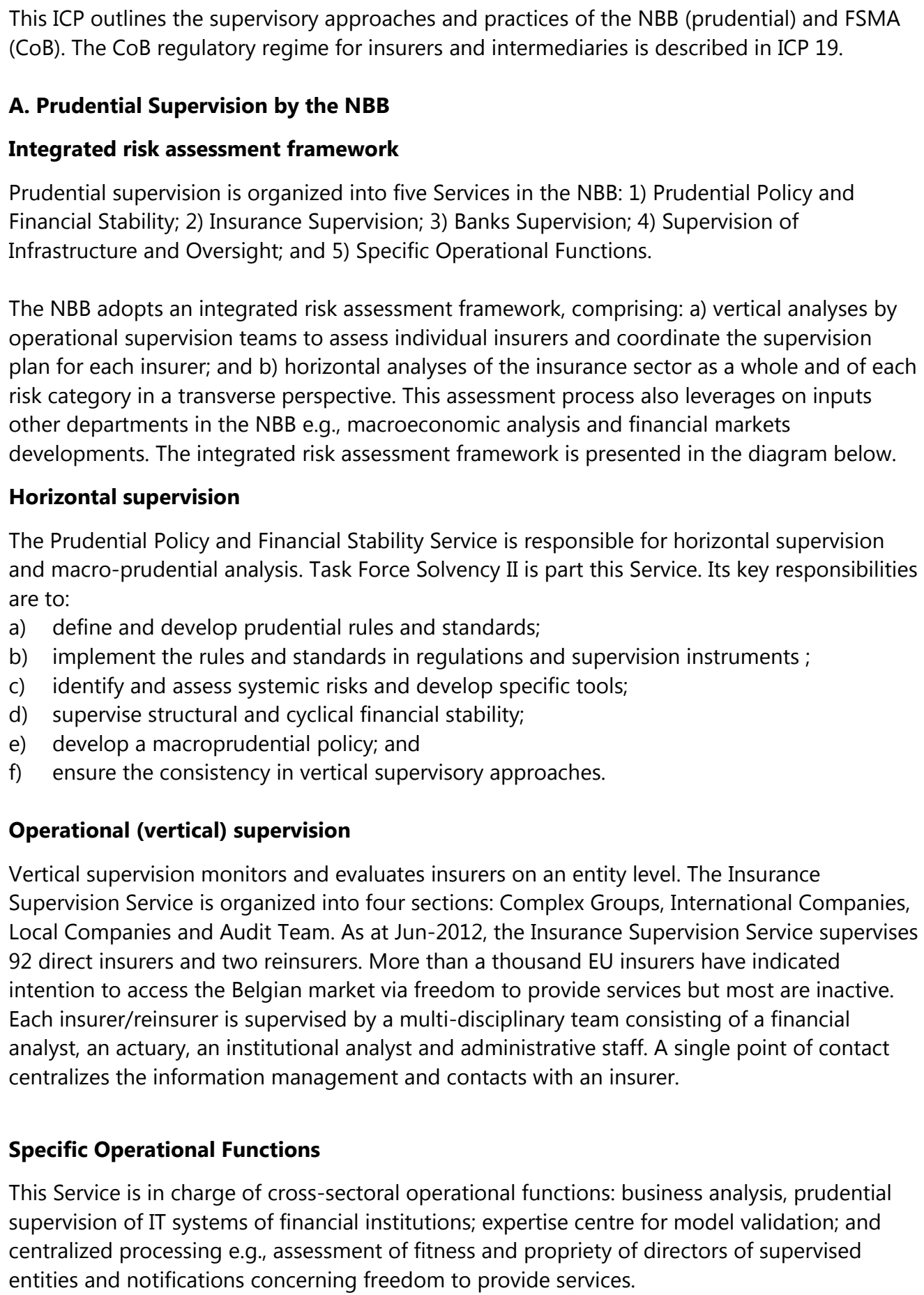 \\
\hline
\end{tabular}




\section{Consultative Bodies}

Three consultation bodies have been created to promote the quality and effectiveness of supervision:

a) Prudential Planning and Coordination Committee oversees the operational organization of prudential supervision;

b) Risk Committee directs the risk analyses, ensures the consistent application of regulations, and organizes the interaction between the micro- and macro-prudential dimensions of supervision; and

c) Macro-financial Committee is responsible for facilitating the interaction between the prudential functions and other macroeconomic and financial functions.

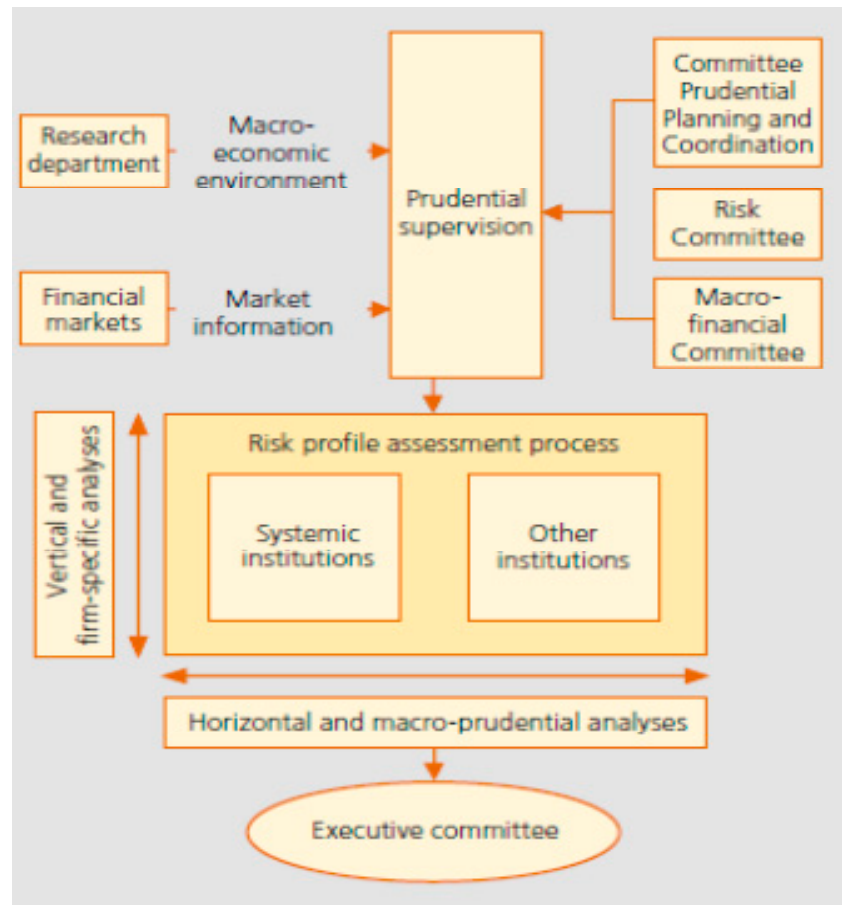

Source: NBB

\section{The NBB's Supervisory Review Process}

The NBB's risk-based supervisory process consists three dimensions: a) internal governance control structure and internal audit of insurers (ICPs 7, 8 and 16); b) contribution of accredited external auditors appointed by insurers under strict and precise legal provisions; and c) direct supervision by the NBB via offsite surveillance and onsite inspections.

The NBB plans to categorize insurers into clusters based on their risk profiles and determine a baseline supervisory program for each cluster. In this regard, it is critical that the NBB plans for adequate supervisory resources to ensure appropriate intensity and effectiveness of its supervision.

\section{Offsite Surveillance and Analysis}

The Scorecard system has been implemented for insurance supervision since January 2012, this is an IT tool providing the operational structure for determining prudential priorities 
according to:

- the importance of an institution and its activities for the Belgian financial system (impact score)

- $\quad$ the quality of an institution's shareholders (shareholders support score); and

- $\quad$ an institution's risk profile (risk score).

The Scorecard facilitates proper documentation of assessments as the basis for a structured dialogue with insurers, accredited external auditors or other prudential authorities, notably in the context of colleges. The instructions for completing the scorecard also provide guidance to supervisors in assessing each area.

An institution's risk score is based on four cornerstones: a) general factors such as governance and financial position; b) control and support functions, e.g., internal audit, compliance and risk management; $c$ ) risks inherent in its activities; and d) internal process of assessing capital needs (which will be implemented with the ORSA requirement under Solvency II). Information and scores are updated on an on-going basis to reflect prudential actions and conclusions.

Su pervisory Review Process

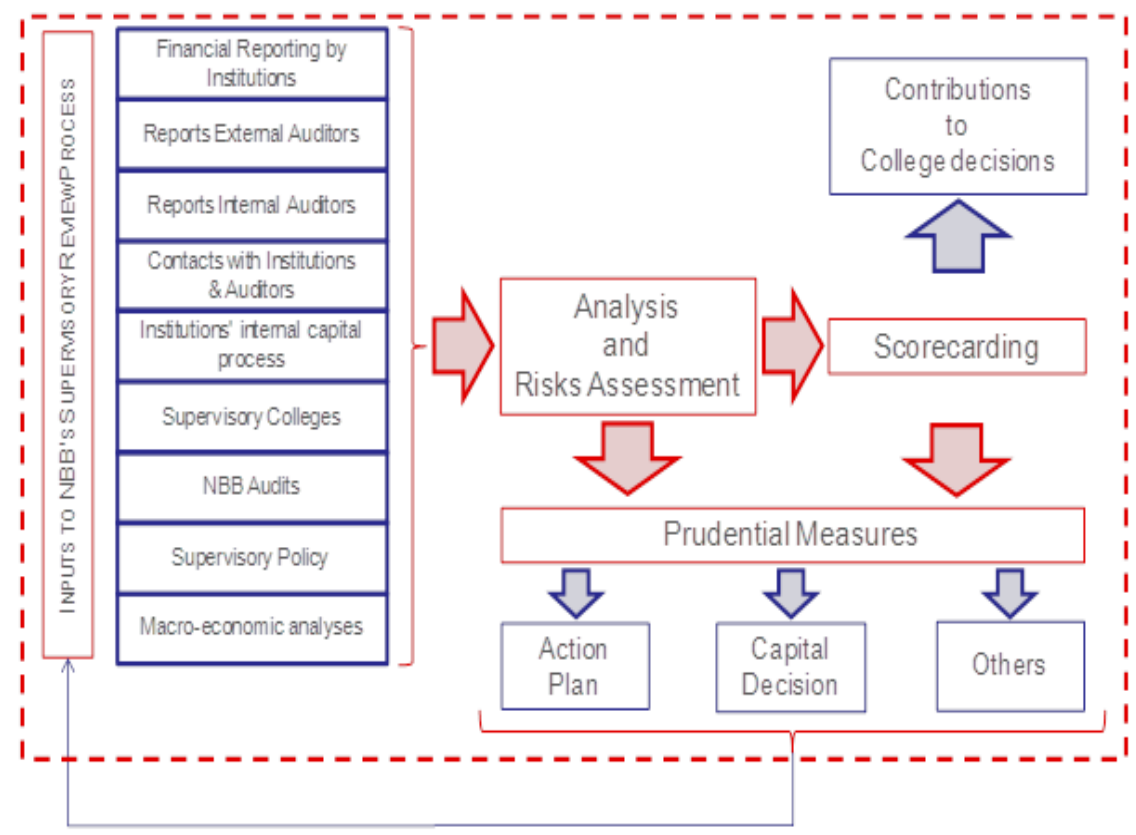

Source: National Bank of Belgium.

Several reports documents are available in the Scorecard at individual insurer, peer group or sectoral levels. Once a year, a validation process is carried out before the information in the Scorecard is stored for future use. The validation process involves all levels of hierarchy within the prudential departments, which helps to promote consistent assessments.

The Insurance Law, RD-IL and RD-Accounts establish the legal basis for insurers to submit supervisory returns and information to the NBB, both at the solo and group levels. On the basis of these legal provisions, the NBB prescribe the information to be submitted via communications or circular letters, which allows more flexibility in modifying the format, content and frequency of reporting. The NBB may also obtain more specific additional information whenever necessary, on a case-by-case basis. (Art 21 to 23bis, Art 69 \& Chapter VIIbis of IL, Art 7bis of RD-Accounts) 
Routine supervisory information is transmitted electronically by using software approved by the NBB. The electronic reporting is subject to various automatic validation tests before being integrated in the NBB's database. The systems facilitate generation of reports based on data queries etc and the computation of early warning indicators e.g., financial and technical ratios to detect deviations from industry benchmarks or other criteria. The analysis of the early warning indicators is supplemented by other information received (questionnaires, reports of the statutory auditor or the accredited actuary) and serves as inputs into the Scorecard for each insurer.

For the systemically important insurers, the evaluation of their risk scores and their risk management system are discussed at the triennial meetings between the NBB and the senior management of the insurers.

Insurers are required to report their outsourcing arrangements to the NBB and to notify the NBB whenever there are material changes to: the financial or administrative organisation, especially with regard to the articles of association, directors, effective management, related parties etc; $b$ ) the direct or indirect shareholding structure or the qualifying holdings. (Circular PPB-2006-01-CPA of 6 February 2006Art 23 \& 23bis of IL)

Senior management of insurers must confirm that the transmitted information is correct and complete, and that the information has been submitted in line with the instructions of the NBB. Financial information and reports on solvency margin are audited annually. The appointed actuary is required to report on insurers' premium rates, reinsurance, adequacy of technical provisions and profit sharing/distributions to the NBB. (Art 22, 38-40quater and 40quinquies of IL).

The NBB periodically reviews the reporting requirements to take account of changes in legislations/regulations, market developments or supervisory experience to improve the quality of reporting. A working group has been set up in the NBB and it meets at least four times a year to discuss the adequacy of reporting and reporting. It is composed of representatives of the operational department and of the Prudential Policy and Financial Stability Service.

However, the delays in the implementation of Solvency II have implications on the quality of regulatory reporting by the NBB. In anticipation of the implementation in 2014, the NBB has held back updating the reporting requirements e.g., the current reports by insurance groups focus more on qualitative aspects and the existing reporting templates on intra-group transactions were considered inadequate. The NBB has been supplementing the reporting gaps via ad-hoc reporting which might result in inconsistent practices across groups or insurers.

\section{Onsite Inspections}

Risk-based inspections are conducted by the Audit Team to evaluate insurers' business activities and the related risk management practices, except in the areas of internal models and IT. The Audit Team started operations in early 2012 and has 12 FTEs at the time of assessment. Each assignment is entrusted to a pair of auditors, taking into consideration of their specialization and skills profiles. The separation of (continuous) offsite surveillance from onsite inspections is intended to provide better checks and balance.

The NBB is authorized to inspect insurers' operations in Belgium as well as their branches in other EEA state after giving prior notification of the host supervisor. (Art 21 of IL) 
A Steering Group within the Insurance Supervision Service validates the annual action plan (including the audit plan). The Audit Team reports periodically report to the Steering Group, inter alia on the progress of the audit plan, any assignments performed outside the plan, key findings and results as well as any general trends observed.

The inspection process is guided by: setting objectives that are tailored to the circumstances for each insurer; standardised work programme (applied in a proportionate manner); an introductory meeting with the insurer to clarify the context and purpose of the inspection; formal documentation for audit trail; informal debriefing meetings and a concluding meeting to present the inspection report. At the concluding meeting, the Audit Team gets an initial reaction from the insurer and their proposals to address the findings and recommendations. The final report is sent to insurer with an accompanying a letter specifying the timetable for their implementation of the agree measures, which will be monitored by the NBB.

The NBB may undertake different types of inspections: specific examination of activities/risks identified on the basis of offsite analysis; thematic examination of a specific activity or a specific risk in several insurers; examination of a specific topic in response to irregularities or deficiencies detected (fraud, crisis management); and surveys to understand an insurer's business and its risk management.

\section{Role of Accredited Auditors and Actuaries}

Insurers can only appoint external auditors who are accredited by the NBB. The accreditation is based on criteria established by the NBB. The NBB has the power to remove accredited auditors under specified circumstances and in accordance with procedures set out in the law. (Art 38-40ter of IL)

- The NBB leverages the work of the accredited auditors, in accordance with the relevant supervisory laws. The role of the external auditors include: a) commenting on insurers' internal controls and communicate their findings to the NBB annually; b) confirming that the semi-annual (limited assurance report) and annual prudential returns (reasonable assurance report) submitted by insurers are complete, accurate and complies with the NBB's instructions; and c) verifying that the valuation basis for prudential returns, including TP, is the same as those applied to annual financial statements. Where deemed appropriate, the NBB may request an external auditor to prepare a special report on the activities and/or financial position of an insurer. The NBB has issued circulars on the reporting by external auditors. (Art 40quater of IL)

- There are merits for considering a review of the effectiveness of the accredited auditors' contributions. For example, the scope for commenting on insurers' internal controls is limited to the completeness and coherence of an insurers' submission. Unless an auditor conducts additional work on internal controls, the review would be based on the auditor's assessment incidental to the financial audit. While such audit checks are sufficient for the expression of an opinion on the financial statements, this is insufficient as an external assurance that all the controls documented are accurate an/or operating effectively.

- External auditors may, at their own initiative, inform the NBB of facts and developments that: have significantly impact on an insurer's financial position; indicate breaches of laws, regulations or the insurer's internal policies; or they intend to issue a qualified opinion or not to certify the financial statements. The Institute of External Auditors has published professional standards on the external auditors' contribution to the supervisory process. This standard is approved by the Minister and is binding on external auditors. Legal 
immunity is provided to external auditors who have communicated information in good faith. The NBB received one notification from an accredited auditor in 2012. (Art 40quater of IL)

In contrast, actuaries play a more limited formal role in the supervisory process. There is no prescribed statutory role for actuaries or a concept of an appointed actuary and there is no provision for whistle blowing by the actuarial function. In practice, the NBB may request additional information from actuaries on pricing, technical provisions and ALM etc on an informal basis.

\section{Supervision of Outsourcing}

The NBB expects insurers to observe the requirements relating to outsourcing as outlined in its Circular. The circular provides, inter alia, that the NBB and the statutory auditor shall have unhindered access to outsourced activities including onsite inspection. It is, therefore, a responsibility of insurers to take the necessary steps to ensure that this is made possible e.g., by having clear provisions in the outsourcing agreement. In addition, outsourcing should not hinder audit work by the statutory auditor. At the time of assessment, the NBB has not conducted any inspection on service providers undertaking activities outsourced by insurers. (Circular PPB-2006-1-CPA)

Where activities are outsourced to entities outside Belgium, two approaches are adopted: a) if the service provider is subject to prudential supervision in the EEA, the NBB may, if necessary, call upon existing cooperation structures under European law; and b) for outsourcing to entities outside the EEA, the NBB should be notified in advance in order to give due consideration to the adequacy of supervision in the host country and the regime for information exchange and cooperation between the NBB with the host supervisor.

\section{B. Supervisory approaches and practices of the FSMA (CoB)}

Pursuant to the implementation of the Twin Peaks legislation, extending the Markets In Financial Instruments Directive (MiFID) rules of conduct to insurers and insurance intermediaries, the FSMA has full responsibility for supervising CoB of these regulated entities, who are subject to a general obligation to act fairly, honestly and professionally in the best interests of their client and to provide them with correct, clear and not misleading information.

For the time being, $\mathrm{CoB}$ supervision for the insurance sector is regulated by the general contract law, the general Law of 6 April 2010 on trade practices and consumer protection (TP\&CP Law), the Insurance law and the Law of 25 June 1992 on terrestrial insurance policies (TIP law). The TP\&CP Law establishes that consumers must be treated fairly both before and after the contract is entered into, and that unfair trade practices against consumers are prohibited. It also specifies that misleading and aggressive practices are considered unfair trade practices. (Art 84 to 94 of TP\&CP Law)

The FSMA's supervising competences are limited to ensuring the respect of the TIP law and the Supervision law. The FSMA can take a wide range of possible actions in the course of carrying out its supervisory tasks:

a) A contact point where insurers and intermediaries can turn to for information and explanations of the rules of conduct;

b) Issuance of circulars, communications, recommendations and moratoria to explain and indicate how the FSMA will apply the rules to facilitate compliance;

c) Imposition of a variety of corrective measures. For example, requiring insurers to correct advertising materials for financial products;

d) Requiring the submission of documentation and information, and conducting on-site 


\begin{tabular}{|c|c|}
\hline & $\begin{array}{l}\text { inspections to verify compliance with the rules; and } \\
\text { e) Taking enforcement and sanctions measures (ICP 11). } \\
\text { Given the large number of regulated entities ( } 17,284 \text { insurance intermediaries) supervised by } \\
\text { the FSMA, its supervisory activities are typically driven by external triggers and there is no } \\
\text { baseline or routine supervisory plan. The external triggers could be from dissatisfied } \\
\text { policyholder and claimants, the Ombudsman, reports from insurers, industry associations or } \\
\text { press reports. The FSMA does not receive regular regulatory reports, as the vast majority of its } \\
\text { supervised entities are individuals and small businesses. Consequently, it is unable to } \\
\text { formulate a risk-based supervisory plan. Where on-site inspections of intermediaries are } \\
\text { conducted, the focus is on checking with compliance with registration requirements. There has } \\
\text { not been any inspection on service providers undertaking activities outsourced by insurers. } \\
\text { In } 2011 \text {, the FSMA focus its supervision on insurers' compliance with the legal provisions } \\
\text { relating to premium advice notes and premium changes. This was prompted by a survey of a } \\
\text { representative sample of insurers, which revealed gaps in compliance. }\end{array}$ \\
\hline Assessment & Largely Observed. \\
\hline Comments & 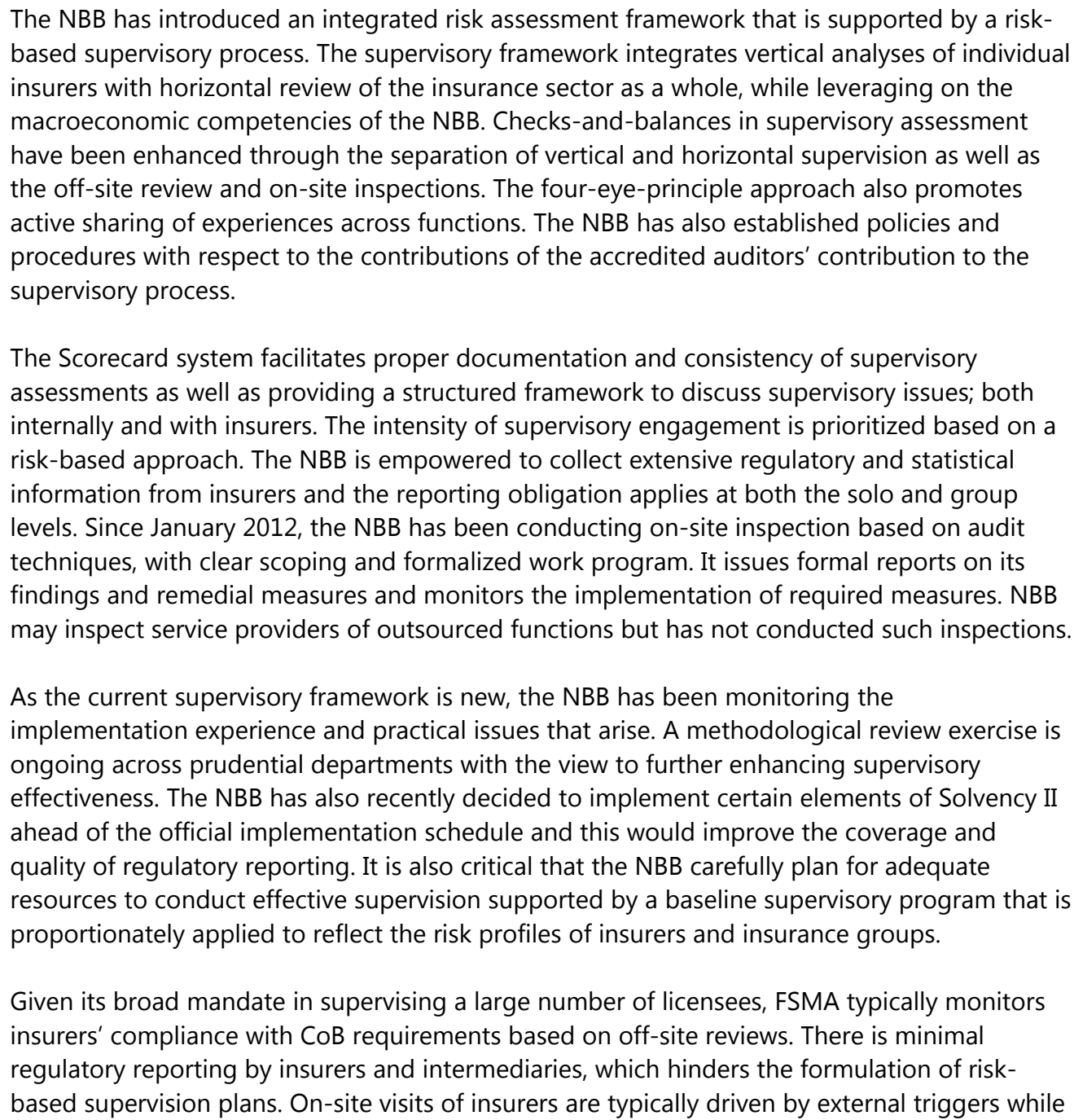 \\
\hline
\end{tabular}




\begin{tabular}{|c|c|}
\hline & $\begin{array}{l}\text { the inspections of intermediaries focus mainly on compliance with registration requirements. } \\
\text { The authorities' decision to implement Solvency II ahead of the official launch date is a positive } \\
\text { initiative. In addition, the effectiveness of on-going supervision could be strengthened by: } \\
\text { a) Developing an appropriate baseline supervisory program for insurers/insurance groups } \\
\text { according to their risk profiles; } \\
\text { b) Strategizing an appropriate risk-based CoB supervision by the FSMA to cover the large } \\
\text { number of registered entities, to better prevent misconduct by insurers and intermediaries } \\
\text { rather than the current more reactive approach. To this end, it is advisable for the } \\
\text { authorities to empower the FSMA to establish appropriate off-site reporting by insurers } \\
\text { and intermediaries; } \\
\text { c) Reviewing the scope and effectiveness of leveraging on the work of external auditors and } \\
\text { actuaries in the supervisory process; } \\
\text { d) Establishing internal policies for inspecting outsourced functions by the NBB and FSMA; } \\
\text { and } \\
\text { e) Ensuring that both the FSMA and the NBB are equipped with adequate supervisory } \\
\text { resources including the technical capacity to achieve the appropriate coverage and } \\
\text { supervisory intensity. }\end{array}$ \\
\hline ICP 10 & $\begin{array}{l}\text { Preventive and Corrective Measures } \\
\text { The supervisor takes preventive and corrective measures that are timely, suitable and } \\
\text { necessary to achieve the objectives of insurance supervision. }\end{array}$ \\
\hline Description & $\begin{array}{l}\text { The Insurance Law and Reinsurance Law prohibit unauthorised insurance activities in Belgium } \\
\text { and contracts concluded by unauthorised entities may be declared void. (ICP4). The offence is } \\
\text { also punishable by imprisonment of up to } 5 \text { years and/or a fine of up to } € 5 \text { million. As these } \\
\text { are criminal sanctions, the penalties are not imposed by the NBB but by the criminal courts. } \\
\text { The FSMA is expected to contribute to enforcing compliance with authorisation requirement. } \\
\text { (Art } 83 \text { of IL). } \\
\text { A distinction is made between the power to authorize insurers, which is the responsibility of } \\
\text { the NBB, and the power to police the illicit offer of insurance contracts, which is the } \\
\text { responsibility of the FSMA. (RD-TP) } \\
\text { If the FSMA determines that a person is offering financial services without the requisite } \\
\text { authorization, it publishes a warning and brings it to the attention of the judicial authorities. } \\
\text { On the basis of information received from third parties and its own observations, the FSMA } \\
\text { opened } 142 \text { dossiers in } 2011 \text { relating to possible unlawful offers of financial services and } \\
\text { issued } 23 \text { warnings in } 2011 \text { to alert the public. The FSMA also publishes warnings from its } \\
\text { European counterparts and published } 538 \text { such warnings in } 2011 \text {. } \\
\text { The NBB follows up with insurers/reinsurer on issues, minor shortcomings and concerns } \\
\text { detected during its ongoing supervision. If an insurer or reinsurer breaches the requirements } \\
\text { of the law or there are supervisory concerns about its financial solvency or internal controls, } \\
\text { the NBB may require rectification within a specified timeframe (Art } 26 \text { of IL and Art } 47 \text { of RL). } \\
\text { The NBB may also take preventive measures such as opposing insurers' proposals e.g., to } \\
\text { effect portfolio transfers or require submission of additional or ad-hoc information. The NBB } \\
\text { typically uses moral suasion as an initial approach, before resorting to a formal intervention. } \\
\text { Where insurers/reinsurers are unable or unwilling to address its concerns satisfactorily, it may } \\
\text { invoke appropriate enforcement and sanctions. In case of extreme urgency the NBB may }\end{array}$ \\
\hline
\end{tabular}




\begin{tabular}{|c|c|}
\hline & $\begin{array}{l}\text { impose enforcement measures without first determining a period within which non- } \\
\text { compliance has to be remedied (ICP 11). } \\
\text { As the NBB possesses a range of options that could be applied in a proportionate manner, it is } \\
\text { able to impose progressive actions and remedial measures. } \\
\text { The NBB is empowered to require insurers to submit a recovery plan to restore solvency or a } \\
\text { short-term finance scheme if the solvency margin is below the required guarantee fund. } \\
\text { Where the rights of policyholders and/or insured persons may be threatened by deterioration } \\
\text { in the financial position of an insurer, the NBB may require the insurer to submit a financial } \\
\text { recovery plan for the subsequent three financial years, showing: a) estimates of management } \\
\text { expenses; b) a detailed forecast of income and expenditure in respect of direct business, } \\
\text { reinsurance acceptances and reinsurance cessions; c) a forecast balance sheet; d) estimates of } \\
\text { the financial resources intended to cover the liabilities and the required solvency margin; e) } \\
\text { the overall reinsurance policy. (Art } 26 \text { } \$ 6 \text { to } \$ 8 \text { of IL) }\end{array}$ \\
\hline Assessment & Observed. \\
\hline Comments & $\begin{array}{l}\text { Unauthorized insurance activities constitute an offence under the Insurance Law and the NBB } \\
\text { and FSMA may refer such cases for prosecution. The NBB has, at its disposal, a range of } \\
\text { preventive and corrective measures that supports the progressive escalation of actions. Before } \\
\text { taking such measures, the NBB exercises moral suasion and works with the insurers concerned } \\
\text { to rectify any deficiencies within a specified timeframe. }\end{array}$ \\
\hline ICP 11 & $\begin{array}{l}\text { Enforcement } \\
\text { The supervisor enforces corrective action and, where needed, imposes sanctions based on } \\
\text { clear and objective criteria that are publicly disclosed. }\end{array}$ \\
\hline Description & $\begin{array}{l}\text { The NBB } \\
\text { Where the NBB determines that there are grounds for imposing an administrative fine or a } \\
\text { penalty, the NBB Board shall decide to initiate an investigation by an Auditor. The Auditor is a } \\
\text { NBB staff member designated by the Council and is independent in the performance of his } \\
\text { duties as Auditor. The Auditor may exercise all the powers of investigation vested in the NBB. } \\
\text { (Art 36/9, NBB Organic Law) } \\
\text { In conducting an investigation, the NBB may demand all necessary information from } \\
\text { supervised entities and from all third parties permitting the activities to take place. Persons } \\
\text { who hinder the NBB's investigations may incur penalties. (Art } 36 / 19 \text { \& } 20, N B B \text { Organic Law) } \\
\text { At the end of the investigation, the Auditor shall submit a report to the NBB Board, who shall } \\
\text { decide whether to: } \\
\text { a) Close the case and inform the persons concerned of the decision; } \\
\text { b) Propose a compromise settlement. A compromise settlement shall be published on the } \\
\text { NBB's website without names; } \\
\text { c) Send a notification of grievance to the Sanctions Committee, together with the } \\
\text { investigation report. If the NBB Board considers that the grievances can lead to the } \\
\text { imposition of a penalty, this shall be expressly mentioned; or }\end{array}$ \\
\hline
\end{tabular}


d) Inform the Crown prosecutor if a breach constitutes a criminal offence and may make its decision public. If the Crown prosecutor decides to start criminal proceedings, the NBB has to be informed.

The decisions above are not open to appeal. (Art 36/10, NBB Organic Law)

The Sanctions Committee comprises six members ${ }^{34}$ appointed by the King for renewable sixyear term. There are clear provisions on their membership to ensure their independence from the NBB, supervised entities and industry associations. At the time of assessment, the Sanctions Committee was not operational, which has implications for the NBB's proposal to impose administrative sanctions. (Art 36/8, NBB Organic Law)

The Sanctions Committee decides on whether the NBB should impose administrative fines and penalties. The European Convention on Human Rights requires a strict division in decisionmaking i.e., the NBB Board that has the power to require an investigation should not be the body to impose sanctions. The NBB is currently looking into the possibilities of deciding on some administrative fines without going to the Sanctions Committee.

Persons affected by the NBB's decision to impose sanctions must submit their responses to the Sanctions Committee within two months. If the notification of grievance mentions that the charges could give rise to the imposition of a penalty, this period is reduced to eight days, unless extended by the Sanctions Committee. (Art 36/11, NBB Organic Law)

The levels of fines or penalties imposed are set in accordance with the seriousness of the breaches committed and in relation to any benefits or profits that may have been drawn from these breaches. The Sanctions Committee publishes its decisions on the NBB's website, unless such publication risks threatening financial stability or will be disproportionately detrimental to interested parties, in which case the decision shall be published without names. (Art 36/11, NBB Organic Law)

An appeal against a sanction decision shall be published without names, pending the outcome of the legal proceedings. An appeal against any decision by the NNB imposing a penalty or an administrative fine may be made with the Brussels Court of Appeal. Such appeals would suspend the decision of the NBB. (Art 36/11 \&21, NBB Organic Law)

The NBB is empowered to take the following enforcement measures:

a) Appoint a Special Commissioner, whose remuneration shall be paid by the insurer. Members of the Board and management committee and Senior Management of insurers who take actions or decisions without authorization from the Special Commissioner are jointly and severally liable for damages claimed by the insurer or third parties.; (Art $26 \$ 1$ $1^{\circ}$ of IL)

b) Suspend all or part of the business activities of the insurer; (Art $26 \$ 12^{\circ}$ of IL)

c) Order the replacement of managers, directors or authorized agents of an insurer within a time limit; (Art $26 \$ 13^{\circ}$ of IL)

d) Revoke authorization; (Art $26 \$ 14^{\circ}$ and 43 of IL and Art 53 of RL)

${ }^{34}$ Comprises a State counsellor; a counsellor at the Court of Cassation; two magistrates who are neither members of the Court of Cassation, nor of the Brussels Court of Appeal; and two other members. 
Measures a) to d) can be imposed after giving the insurer a timeframe to comply, but in urgent cases, the NBB can also apply this measure without first stipulating a recovery period.

e) Restrict or prohibit the free disposal of the assets under specified grounds; (Art $26 \S 5$ of IL)

f) Require a recovery plan to restore solvency or a short-term finance scheme if the solvency margin is below the required guarantee fund; (Art $26 \$ 6$ of IL)

g) Require a three-year financial recovery plan and or impose higher solvency margin, if policyholders' interest may be compromised; (Art $26 \$ 7 \&$ \&8 of IL)

h) Take resolution measures (see below);

i) Recommend that an insurer be merged or taken over by another insurer. However, this authority does not apply to reinsurers; and (Art 27 of IL)

j) Apply administrative sanctions: a) publicise in the Belgian Official Gazette the orders issued to insurers, insurance holding mixed activity holding companies or mixed financial holding companies if these entities fail to meet the orders; impose administrative fines (up to a maximum of $€ 1,250,000$ ) if an insurer does not address deficiencies noted within the time period stipulated by the NBB or the FSMA. (Art 81-82 of IL \& Art 73-74 of RL)

The NBB shall inform the FSMA of decisions to take the above measures and keep the FSMA informed of the outcome of appeals against its decision to revoke an authorization.

Directors, managers or agents who knowingly and deliberately make untrue declarations to the FSMA or the NBB, or refuse to provide the information requested shall be punished by imprisonment for up to five years and/or a fine up to $€ 5$ million. (Art 85 of IL and Art 75 of RL)

In practice, the NBB has taken the following enforcement and sanction measures: fines (so far only for administrative reasons); a capital increase pursuant to a recovery plan; compulsory transfer of assets; refusal to approve the appointment of effective management (only at the stage of authorization); forced sale of a portfolio; a financial recovery plan and a higher required solvency margin; designation of a special commissioner; replacement of directors; prohibit disposal of assets; suspension of voting rights attached to the shares; and withdrawal of authorization.

Administrative sanctions are enforced by the NBB and criminal sanctions are enforced by the Belgian criminal courts.

Resolution measures_(does not apply to reinsurers)

The NBB may initiate the resolution of a problematic insurer. If the NBB is not the initiator, it must render its advice to the government. The Insurance Law states that the King may take disposition measure in favour of the Belgian State or any other Belgian or foreign person, via a Royal Decree established after consultation in the Board of Ministers. Such disposition includes the transfer or sale of: assets and liabilities, one or more lines of business or a part or total obligations of the affected insurer; or voting shares. (Art 26bis of IL)

\section{The FSMA}

The enforcement powers of the FSMA include:

a) Publishing warnings on unauthorized activities and reporting the circumvention to judicial authorities; 


\begin{tabular}{|c|c|}
\hline & 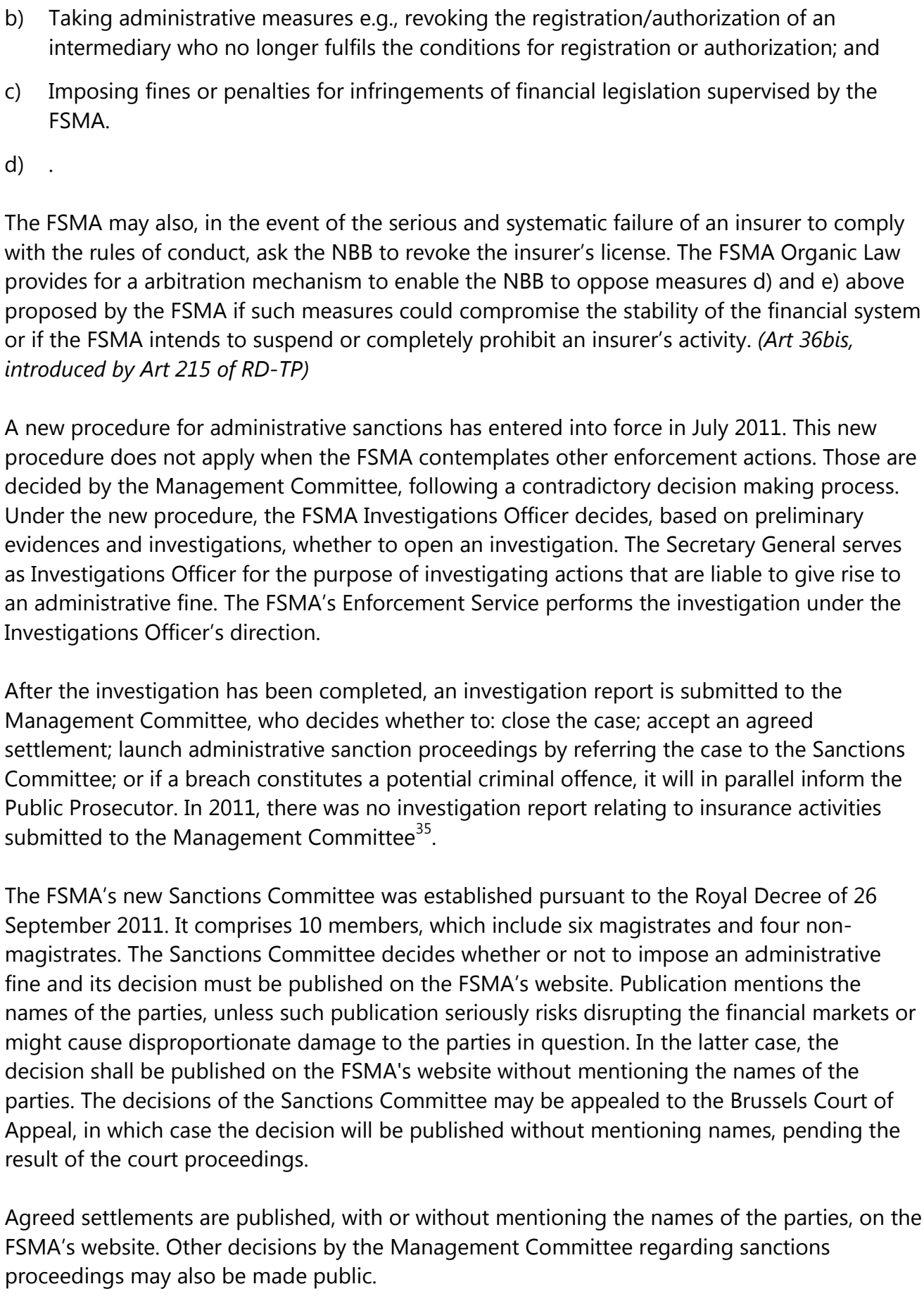 \\
\hline Assessment & Observed. \\
\hline
\end{tabular}

${ }^{35}$ Twelve reports were submitted with respect to capital market activities. 


\begin{tabular}{|c|c|}
\hline Comments & $\begin{array}{l}\text { The NBB and the FSMA have a wide range of powers to take enforcement action and impose } \\
\text { sanctions, if insurers are unable or unwilling to address supervisory concerns in a timely } \\
\text { manner. A transparent process and the engagement of the Sanctions Committees (to be } \\
\text { established) in the NBB and of the Sanctions Committee of the FSMA helps to ensure } \\
\text { proportionate and consistent sanction decisions. }\end{array}$ \\
\hline ICP 12 & $\begin{array}{l}\text { Winding-up and Exit from the Market } \\
\text { The legislation defines a range of options for the exit of insurance legal entities from the } \\
\text { market. It defines insolvency and establishes the criteria and procedure for dealing with } \\
\text { insolvency of insurance legal entities. In the event of winding-up proceedings of insurance } \\
\text { legal entities, the legal framework gives priority to the protection of policyholders and aims at } \\
\text { minimizing disruption to provision of benefits to policyholders. }\end{array}$ \\
\hline Description & 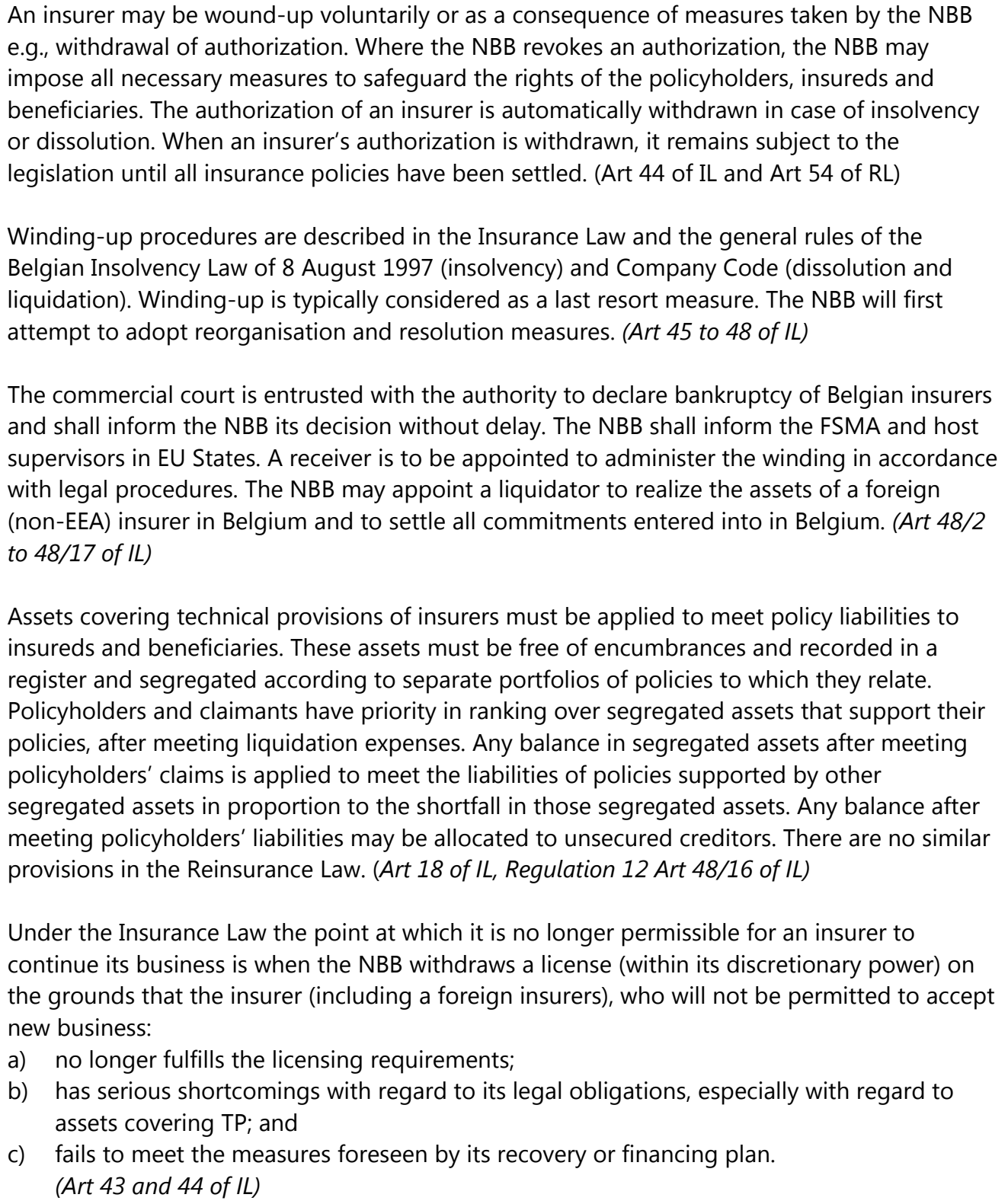 \\
\hline
\end{tabular}




\begin{tabular}{|c|c|}
\hline & $\begin{array}{l}\text { In the case of insolvency proceedings (bankruptcy) or dissolution, the license is automatically } \\
\text { revoked i.e., the NBB has no discretionary power. }\end{array}$ \\
\hline Assessment & Observed. \\
\hline Comments & $\begin{array}{l}\text { The winding-up of insurers is based on the procedure set out in the Insolvency Law } \\
\text { (insolvency) and the Company Code (dissolution and liquidation), subject to certain insurance- } \\
\text { specific modifications set out in the Insurance Law. Policyholders have priority of claim above } \\
\text { other unsecured creditors in the event of a winding-up. The Insurance Law determines the } \\
\text { point at which it is no longer permissible for an insurer to continue its business. }\end{array}$ \\
\hline ICP 13 & $\begin{array}{l}\text { Reinsurance and Other Forms of Risk Transfer } \\
\text { The supervisor sets standards for the use of reinsurance and other forms of risk transfer, } \\
\text { ensuring that insurers adequately control and transparently report their risk transfer } \\
\text { programmes. The supervisor takes into account the nature of reinsurance business when } \\
\text { supervising reinsurers based in its jurisdiction. }\end{array}$ \\
\hline Description & $\begin{array}{l}\text { For life insurers who qualify for exemption from the Flashing Light provision, Circular } \\
\text { CPA_2006_1_CPA requires that their ALM models have to take into account outward } \\
\text { reinsurance. } \\
\text { Circular CBFA_2009_33 of } 19 \text { November } 2009 \text { (on the actuarial function) requires the actuarial } \\
\text { function to express annually an opinion on the adequacy of reinsurance arrangements and, } \\
\text { where necessary, during the launch or the changes of a product. } \\
\text { Communication D.57 of } 17 \text { December } 1981 \text { (on recoverables from reinsurers) and } \\
\text { Communication D.135 (on the use of reinsurance receivables in the technical provisions) set } \\
\text { requirements on the treatment of receivables and of reinsurers. For reinsurance recoverable, a } \\
\text { guarantee/collateral has to be given to the ceding insurer; and for reinsurers situated in non- } \\
\text { EEC countries, the reinsurer needs to have: at least } 10 \text { years of track record, unqualified } \\
\text { financial accounts for at least seven years; and a minimum amount of free capital. } \\
\text { The actuarial function is required to describe and evaluate annually the reinsurance strategy, } \\
\text { including a justification of the type of reinsurance used, the reinsurance program and other } \\
\text { technical elements of the reinsurance strategy. Justification must be provided for any lines of } \\
\text { business without reinsurance cover. } \\
\text { Insurers that are exempt from the Flashing Light provision must demonstrate that their ALM } \\
\text { models take into account outward reinsurance, including consideration of the time lag } \\
\text { between direct payments made and the corresponding amounts paid by the reinsurer(s). } \\
\text { As part of their annual reporting, all insurers have to fill out a reinsurance questionnaire, which } \\
\text { requires information on: the current reinsurance structure and related reinsurance programs; } \\
\text { reinsurance strategy; and the impact of reinsurance on the solvency capital requirement. } \\
\text { Reinsurers also have to give an annual overview of their reinsurance plan. } \\
\text { Insurers' solvency requirements can be reduced, within certain limits, to take account of } \\
\text { reinsurance. The reduction coefficient (maximum } 50 \text { percent for the non-life business and } 15 \\
\text { percent for the life business) is based on the reinsurers' share of claims payments (Art } 15 b i s \text { of } \\
\text { IL). }\end{array}$ \\
\hline
\end{tabular}




\begin{tabular}{|c|c|}
\hline & $\begin{array}{l}\text { There are no specific requirements or reports for alternative risk transfers relating to special } \\
\text { purpose vehicles. } \\
\text { Supervision } \\
\text { The NBB does not assess the solvency position of the reinsurers participating in the claims } \\
\text { payments. Through the annual reinsurance plan, the NBB is however informed about the } \\
\text { identity of the ceding insurer's counterparties and can conduct further analysis. } \\
\text { During the Scorecarding process, the NBB analyzes the general reinsurance structure, } \\
\text { counterparty credit risk arising from reinsurance, the structure and functioning of reinsurance } \\
\text { and other risk mitigation techniques. } \\
\text { Insurers are required to furnish quarterly and annual supervisory reporting at the solo level on } \\
\text { a BGAAP basis. The NBB's IT Tool calculates a number of ratios automatically (e.g., the } \\
\text { percentage of TP reinsured, and the degree of coverage of reinsured TP by reinsurance } \\
\text { deposits received), giving an indication of the liquidity risk involved. Also, liquidity has to be } \\
\text { considered in the ALM model by those insurers that are exempt from the Flashing Light } \\
\text { provision. } \\
\text { Systemically relevant insurers have to submit a vulnerability report (since Q4 2011), which } \\
\text { contains some data that is related to liquidity, e.g., coverage of reinsured technical provisions } \\
\text { by reinsurance deposits received based on IFRS. }\end{array}$ \\
\hline Assessment & Largely Observed. \\
\hline Comments & $\begin{array}{l}\text { The NBB requires insurers to submit comprehensive information on their reinsurance } \\
\text { programs and its IT Tool calculates standard early warning indicators automatically. } \\
\text { Reinsurance is taken into account in the PCR (solvency margin) using rough proxies and the } \\
\text { risk mitigating effect might be under- or overstated for some forms of reinsurance (e.g., for } \\
\text { non-proportional covers). This has to be balanced with the resources required to perform a } \\
\text { more detailed analysis, particularly for complex reinsurance programs. Reinsurance credit risks } \\
\text { (default and migration risk) are not considered adequately, which may hinder the early } \\
\text { detection of deteriorating credit quality of reinsurers. Similarly, concentration risk arising from } \\
\text { reinsurance ceded to only one or few reinsurers is not considered. } \\
\text { We recommend that the NBB: } \\
\text { a) Strengthen the prudential standards relating to reinsurance, and requires insurers to } \\
\text { embed the management of reinsurance risk as part of their risk management framework, } \\
\text { particularly with respect to counterparty, concentration and liquidity risks arising from } \\
\text { reinsurance; and } \\
\text { b) Formulate appropriate standards applicable for risk transfer to capital markets to facilitate } \\
\text { better understanding of the structure and operations of such arrangements. }\end{array}$ \\
\hline ICP 14 & $\begin{array}{l}\text { Valuation } \\
\text { The supervisor establishes requirements for the valuation of assets and liabilities for solvency } \\
\text { purposes. }\end{array}$ \\
\hline Description & $\begin{array}{l}\text { The valuation of assets and liabilities for solvency purposes has to be done in conformity with } \\
\text { applicable accounting standards, which specify the valuation requirements for solo entities } \\
\text { and for groups (Art } 15 \text { and } 22 \text { of IL). }\end{array}$ \\
\hline
\end{tabular}


At the solo level, the valuation is based on BGAAP and specified in the Royal Decree of 17 September 1994 on the annual accounts of insurers. For groups, the valuation is based on IFRS and specified in Royal Decree of 27 September 2009 on the consolidated accounts of insurance and reinsurance undertakings.

Insurers have to hold, at all times, identified assets covering their TP (covering assets). For covering assets, the valuation approach is market-based, except for sovereign bonds, which are valued at amortized cost less depreciation (Art 10, $\$ 9$ of the RD of 22 February 1991).

All foreseeable risks and possible depreciation/impairment must be taken into account and an impairment test is required with specific provisions by asset classes. Detailed information on investments within the covered assets has to be sent to the NBB regularly in electronic form, including their market values. Re-evaluation above acquisition price (unrealised gains) is recognised for long-term assets only, subject to conditions (Art 19 and 34 of RD 17 November 1994).

Where there are concerns with the valuation basis adopted, which may pose risks to solvency requirements, the NBB may take a range of preventive and corrective measures as well as enforcement action (ICPs 11 and 12).

Each insurer must have an actuarial function (ICP 8). Any change of appointment or dismissal of persons in the actuarial function has to be reported to the NBB. The actuarial function has to provide an opinion on an insurer's TP and reinsurance to Senior Management and to the NBB, annually. The opinion should include an analysis of calculation methods, assumptions, and technical bases for the different provisions. Management is responsible to provide adequate information to the actuarial function.

\section{Solo Level valuation}

Under BGAAP, most assets are valued at amortized or historical cost (except assets covering ILPs). Financial and insurance liabilities are measured at amortized cost. TP to be set up are defined in Article 11 of the Royal Decree of 22 February 1991:

- Life insurance contracts - based on current actuarial assumptions reviewed at each reporting date and with discounting locked at inception;

- Non-Life: Unearned premium reserve plus additional provisions if pricing becomes outdated;

- Claim Reserves: Individual provisions for life and non-life claims covering all expected expenses on an undiscounted basis; and

- Catastrophe and equalization provisions.

\section{Non-Life TP}

Generally, the valuation of TP is highly principles based and insurers are free to choose the calculation methods. Exceptions are being made for certain types of provisions, where calculation methods are being imposed:

- TP for unearned premiums (Communication D.32);

- TP for equalization and catastrophes (Communication D.151);

- TP for workers compensation (Annex VI to RD of 22 February 1991);

- Two specific methods are authorized or imposed in case available information does not allow the TP to be estimated accurately (Art 34septies of RD 17 November 1994); and

- Discounting of the provisions for outstanding claims is authorised under certain conditions (Art 34sexies, $\$ 1,6^{\circ}$ of RD 17 November 1994). 


\section{Life TP}

Life insurers must take into account the adverse deviation of the relevant factors that are used for the calculation of TP. In addition, they have to estimate TP using sufficiently prudent prospective actuarial valuation, taking account of all future liabilities as determined by the policy conditions for each existing contract, including:

- $\quad$ All guaranteed benefits, including guaranteed surrender values;

- Bonuses to which policyholders are already either collectively or individually entitled, however those bonuses are described, vested, declared or allotted;

- All options available to the policyholder under the terms of the contract;

- Expenses, including commissions; and

- $\quad$ Taking credit for future premiums due.

(Art 31 of RD 14 November 2003)

The discount rate used for the calculation of TP of a contract corresponds to the guaranteed interest rate granted by the contract. Insurers have to publicly disclose the bases and methods used for the calculation of the surrender values of policies (Art 31 of RD 14 November 2003).

\section{The Flashing Light Provision}

The Flashing Light provision sets out additional provisions for interest rate risks. The NBB can exempt life insurers from the Flashing Light provision requirement under certain conditions.

The Flashing Light provision requires the gradual build up of TP over 10 years, so that the TP correspond to a discount rate based on 80 percent of the average over the last 5 years of the 10-year OLO (Belgian sovereign bonds).

Where insurers would like to be exempted from the Flashing Light provisions, circular CPA2006-1-CPA requires that for their regulatory reporting and risk management purposes. The same holds for workers' compensation as well as for health insurance contracts. The risk-free interest rate corresponds to the basic risk free interest rate curve established by EIOPA.

Insurers exempted from the Flashing Light provision must have an ALM model in place that is reviewed by the NBB. Shortcomings of the models including governance and documentation would lead to capital add-ons, a graduated recognition of the Flashing Light provision exemption and the requirements to improve the model.

Currently, 23 insurers-including large insurers-are exempted from the Flashing Light provision and therefore are using internal models that are approved by the NBB.

\section{Group Level}

On a group level, a consolidated calculation based on IFRS is done but using prudential filters. The filters are used to bring the IFRS calculation closer to Solvency I and relate to the definition of insurance contracts, unrealized gains and losses on financial assets at fair value and elimination of changes due to insurers' own credit standing (Circular letter 2008-07 of the BFIC of 11 March 2008 on the IFRS prudential filters).

\section{Supervisory Practices}

Methods to calculate TP are systemically analyzed when a new insurer is granted authorization or an existing authorization is extended. The NBB reviews and challenges regularly the valuations (mainly of assets) used by insurers in their accounts and supervisory reporting. This is done through desk-top reviews of reported figures; and complemented by discussions with insurers and external auditors (since the valuations are audited). 


\begin{tabular}{|c|c|}
\hline & $\begin{array}{l}\text { The NBB collects information on TP, profit sharing and reassurance using a questionnaire. This } \\
\text { questionnaire includes a series of questions about the calculation, adequacy and completeness } \\
\text { of the life TP, including simulation of the evolution of different risk factors under scenarios } \\
\text { described in the questionnaire as well as information on the internal controls used to verify } \\
\text { whether TP has been calculated for all contracts and whether the contracts have been } \\
\text { captured correctly in the calculation. }\end{array}$ \\
\hline Assessment & Largely Observed. \\
\hline Comments & 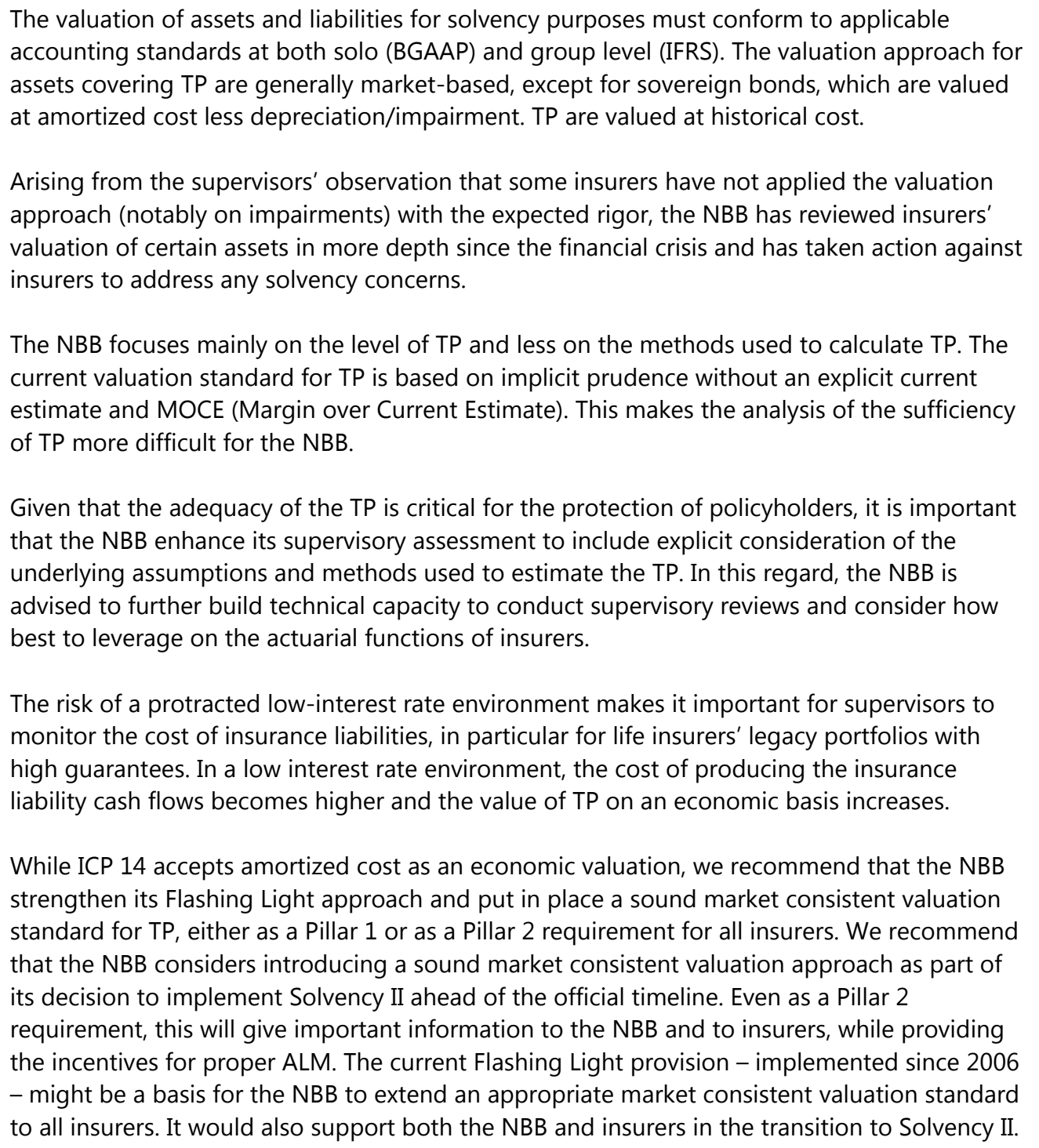 \\
\hline ICP 15 & $\begin{array}{l}\text { Investment } \\
\text { The supervisor establishes requirements for solvency purposes on the investment activities of } \\
\text { insurers in order to address the risks faced by insurers. }\end{array}$ \\
\hline Description & The majority of the requirements on the investment activities of insurers emanate from the \\
\hline
\end{tabular}


Directives applicable to EU Member States. In line with these Directives, the requirements on investments only relate to the assets which are used to cover the TP (covering assets) and not to the other assets (free assets).

The Insurance Law and the Royal Decree of 22 February 1991 establish the main requirements for the covering assets. These legal requirements are complemented by guidelines, mainly on risk management, which are described through circulars and communications. The requirements on the investment activities of insurers for solvency purposes include:

- $\quad$ Requirements on holding assets for covering TP; (Arts 16-18, 26 and 91octies of IL)

- TP to be covered by assets which consider the nature of the insurance activities and which guarantee the safety, liquidity, profitability, congruency, spread and diversification of the investments; (Art 9 and 10 of RD 22 February 1991)

- Requirements on the type of assets and concentration limits per class of assets and per issuer; (Art 10 of RD 22 February 1991)

- Prudential treatment of securities which are used by insurers for repo, reverse repo and securities lending transactions; (Circular CBFA_2009_29 of 30 September 2009)

- The role of the Board in establishing a risk appetite, a risk strategy and the monitoring of the risk management system, as well as key elements of the risk measurement system; (Circular CBFA_2008_13 of 5 Jun 2008)

- Qualitative and quantitative criteria for ALM models, which consider the investment activities from an ALM perspective; and (Circular CPA-2006-1-CPA of 19 September 2006)

- Clarifications on the use of assets to cover TP. (Communications D127, D134, D135, D153, D196, D224 and CBFA_2009_23)

The objectives of the prudential standards on investment are to: 1) ensure that TP are covered with a sufficient amount of assets in order to safeguard the interests of policyholders, the insured and the beneficiaries; 2) protect the rights of the insured or the beneficiaries of insurance policies, who hold a privileged claim on the insurer in going concern and liquidation; 3) ensure that the risks attached to the covering assets are commensurate with the nature of the obligations (Art. 16 to 18 of IL).

Insurers are required to send a quarterly report (electronically) on the covering assets and the amount of the TP covered by the assets. The report includes detailed information on each asset item. The report is automatically tested and validated, with checks on the valuation and coverage, limits etc. Covering assets have requirements relating to, e.g., listed/non-listed securities, quality of the issuer, issuance of the asset, limitations per issuer, asset deposits, required guarantees, congruency, diversification and spread.

Covering assets have to be included in a permanent inventory and take account of the type of operations carried out by an insurer:

- They need to be secure, have a sufficient return, and be liquid, diversified and adequately spread;

- They must meet the localisation rules and be congruous;

- They have to be invested in permitted asset categories and subject to investment concentration limits;

- Non-listed securities are accepted only if they can be realised in the short term;

- Covering assets that are related to transactions with special purpose entities are subject to specific conditions (e.g., risk transfer, financing and governance of the special purpose vehicle);

- Covering assets that are related to repo, reverse repo and securities lending transactions are subject to specific requirements (e.g., property, valuation, risk management, collateral and limits). The NBB may object to an investment;

- The NBB may extend the requirements to covering assets that are held by subsidiaries of 
the insurer;

- The use of derivatives is subject to concentration limits and restricted to instruments that are traded on a public, liquid and well functioning market. Derivatives should be used only to decrease the investment risk or to improve the management of the investment portfolio (i.e., for hedging purposes).

Communication D153 requires insurers to report on the use of derivatives including the volume of transactions for each derivative instrument, the strategy for the use of derivatives, the control procedures, the organisation of the front and middle office, and the risk exposures.

\section{Segregation}

Article 9 of the Royal Decree of 22 February 1991 requires covering assets to be segregated in the following categories:

- Non-Life - direct business, except worker's compensation;

- Non-Life - direct business, worker's compensation;

- $\quad$ Life - direct business, classes specified in Directive 2002/83/EC, except for certain ringfenced funds;

- Investment funds;

- Non-Life - reinsurance acceptances; and

- $\quad$ Life - reinsurance acceptances.

\section{Location}

Covering assets must be located in the European Community. Assets located outside the European Community can also be used as covering assets in certain circumstances. Assets should be deposited in safe custody provided they can be deposited. (Art 16 of IL)

\section{ALM}

For insurers that are exempt from the Flashing Light provision (see ICP 14), Circular CPA-20061-CPA establishes the key supervisory expectations on ALM.

On a yearly basis, insurers exempted from the Flashing Light provision need to provide the NBB with an extensive analysis on their ALM, and more generally, their risk management system (i.e., the risk model file). Elements considered in the supervisory analysis are the segmentation of assets and liabilities, measurement of the interest rate risks (maturity gap, duration and convexity, VaR), use and optimization of simulation/stress testing models, determination of the economic capital, risk management organisation, structure and resources of the insurer, role of the internal audit and advice of the accredited actuary. Consideration has to be given to the assets profile and the matching of cash flows of assets and liabilities over time and under different conditions. Through stress testing and back testing exercises the insurer's investment strategies are assessed.

Circular CPA-2006-1-CPA sets the criteria for evaluating insurers' ALM models:

- Know-how / Expertise: the expertise and knowledge of the members of the risk management department has to be commensurate with the complexity of the risk models, products and activities of the insurer. Members of the front, middle and, back offices, internal audit and other control functions should be sufficiently acquainted with the risk models and related products.

- $\quad$ Governance and Responsibilities: the Board of Directors is expected to establish a risk management policy including the risk appetite and the general risk profile of the insurer, while the senior management is responsible for the development of the risk management system. 


\begin{tabular}{|c|c|}
\hline & 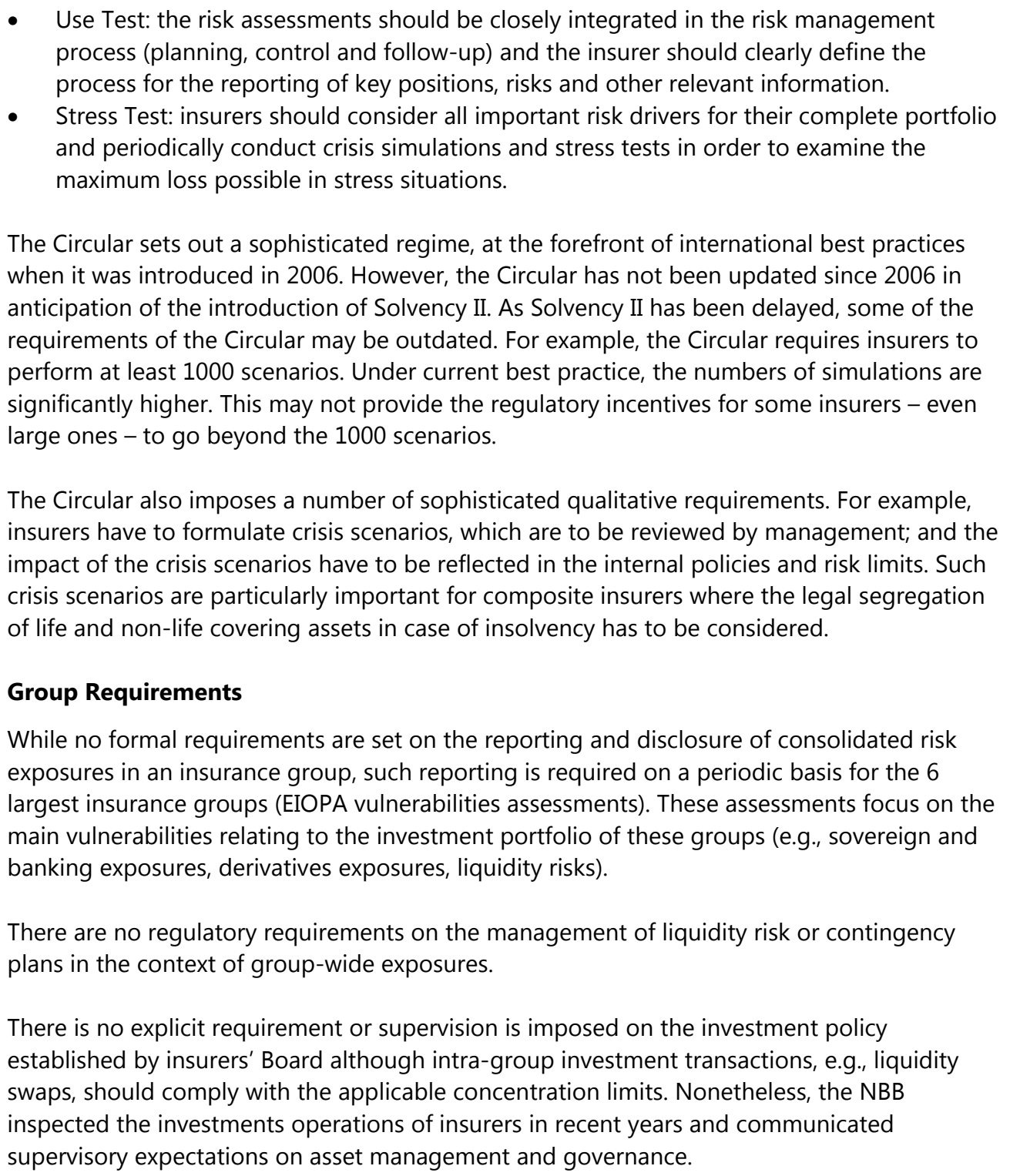 \\
\hline Assessment & Largely observed. \\
\hline Comments & $\begin{array}{l}\text { The regulatory requirements on investments are in line with EU Directives, which apply only } \\
\text { the assets covering insurers' TP i.e., there are no requirements on free assets. ALM } \\
\text { requirements for some insurers have been implemented since } 2006 \text { in relation to the Flashing } \\
\text { Light provision and there is scope for updating the prudential standard to reflect evolving best } \\
\text { practices. In addition, insurers have to formulate crisis scenarios and quantify the impact as } \\
\text { part of their ALM framework. Effective supervision of insurers' ALM hinges on adequate } \\
\text { technical supervisory capacity. } \\
\text { The NBB is currently examining how the risks relating to a low interest environment and the } \\
\text { establishment of an adequate ALM can be better monitored. The implementation of Solvency } \\
\text { II will also establish clearer supervisory expectations as part of insurers' own risk and solvency } \\
\text { assessment. The NBB also intends to enhance its supervisory competences on ALM through } \\
\text { advanced training and development initiatives. }\end{array}$ \\
\hline
\end{tabular}




\begin{tabular}{|c|c|}
\hline & $\begin{array}{l}\text { The mission supports the NBB's proposals to update the prudential standards for ALM to } \\
\text { reflect evolving international best practices and strengthening supervisory capacity to assess } \\
\text { insurers' ALM practices. It is also advisable to establish formal regulatory requirements on the } \\
\text { investments of insurance groups. }\end{array}$ \\
\hline ICP 16 & $\begin{array}{l}\text { Enterprise Risk Management for Solvency Purposes } \\
\text { The supervisor establishes enterprise risk management requirements for solvency purposes } \\
\text { that require insurers to address all relevant and material risks. }\end{array}$ \\
\hline Description & 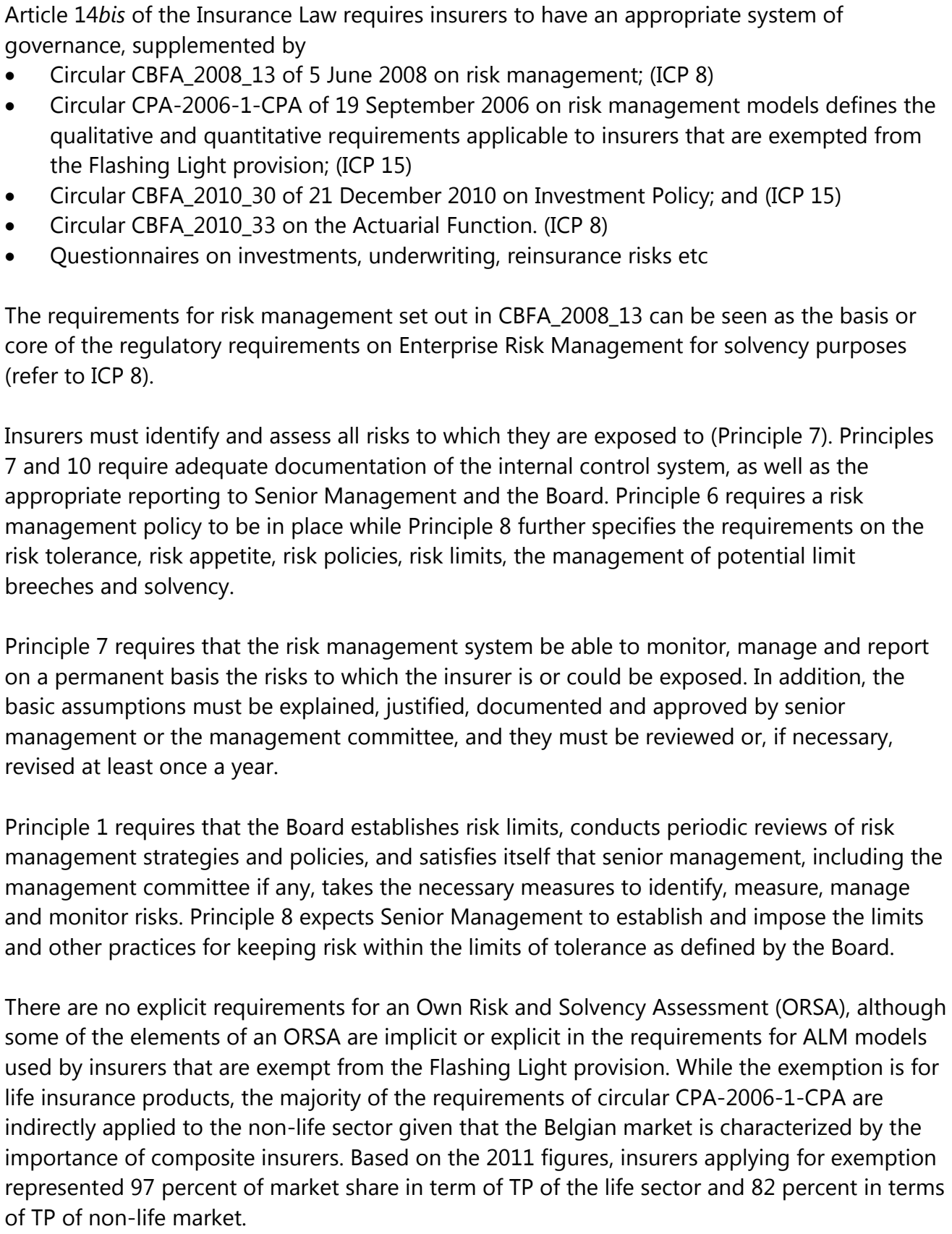 \\
\hline
\end{tabular}




\begin{tabular}{|c|c|}
\hline & $\begin{array}{l}\text { For the ALM model, risk factors with a significant influence on the market value of portfolios } \\
\text { (assets and liabilities) have to be identified and included in the model. Insurers are expected to } \\
\text { compile, at least once a year, a balance sheet and an income statement containing short- and } \\
\text { long-term estimates, as well as a simulation of the needs for equity capital for an identical } \\
\text { period, i.e., insurers must assess their financial position over a longer time horizon than one } \\
\text { year. } \\
\text { The NBB examine insurers' Flashing Light provision based on the criteria of Circular CPA-2006- } \\
\text { 1-CPA on risk management and the use of risk models. This review has been extended, for } \\
\text { some insurers, to the risk management function. Shortcomings of the models including of the } \\
\text { governance and documentation lead to capital add-ons, a graduated recognition of the } \\
\text { Flashing Light provision exemption and the requirements to improve the model. }\end{array}$ \\
\hline Assessment & Largely Observed. \\
\hline Comments & $\begin{array}{l}\text { The current prudential standards have established some elements of the regulatory } \\
\text { requirements for an enterprise risk management by insurers. To meet ICP 16, there should be } \\
\text { clearer requirements and more comprehensive scope on insurers' risk management policy, } \\
\text { particularly for investment and underwriting risks. In addition, enterprise risk management } \\
\text { should be supported by an ORSA. Currently, some elements of ORSA are applicable only to } \\
\text { those insurers that apply for an exemption from the Flashing Light provision. } \\
\text { The NBB's decision to implement ORSA earlier than the official Solvency II timeline will } \\
\text { improve observance of ICP 16. For ORSA to be truly effective as a supervisory tool and also as } \\
\text { a management tool for insurers, it needs to be supported by a sound valuation and risk } \\
\text { assessment framework. } \\
\text { Given the potential risk of a prolonged low-interest rate environment with potentially } \\
\text { declining interest rates, transparency on the long-term financial/economic situation of insurers } \\
\text { is particularly important. As interest rates stay low, the high returns in legacy portfolios are } \\
\text { likely to put pressure on the financial position of life insurers resulting in gradual deterioration } \\
\text { of their financial soundness. An ORSA with a market consistent valuation standard helps to } \\
\text { address this potential risk and would also function as an early warning sign for both the NBB } \\
\text { and the industry. }\end{array}$ \\
\hline ICP 17 & $\begin{array}{l}\text { Capital Adequacy } \\
\text { The supervisor establishes capital adequacy requirements for solvency purposes so that } \\
\text { insurers can absorb significant unforeseen losses and to provide for degrees of supervisory } \\
\text { intervention. }\end{array}$ \\
\hline Description & $\begin{array}{l}\text { The regulatory framework for determining capital adequacy requirements for solvency } \\
\text { purposes is governed by the following legal provisions: } \\
\text { Solo Level: } \\
\text { - Own funds constituting the required solvency margin; (Art. 15, 15bis, 15ter and 15quater } \\
\text { of IL; Art. } 17 \text { of } R D-I L) \\
\text { - Solvency requirement; and (Art. } 18 \text { and } 19 \text { of } R D \text {-IL) } \\
\text { - Corrective actions.(Art. 23bis, } 26,27 \text { and } 43 \text {, of IL) } \\
\text { Group Level: } \\
\text { - Own funds constituting the adjusted solvency margin; (Art. 91nonies and 91decies of IL) }\end{array}$ \\
\hline
\end{tabular}


- $\quad$ Solvency requirement; and (Art. 19bis of RD-IL)

- $\quad$ Corrective actions. (Art. 43, 91 undecies and 91quaterdecies of IL)

Composite insurers:

- $\quad$ The requirement to set up two distinct solvency margins and the rules governing the separation of the solvency margins for both types of activities; and (Art 15 of IL)

- The allocation of the results and the transfer of financial resources between the solvency margins. (Art 17 of $R D-I L$ )

The capital adequacy requirements take account of all businesses carried out by the insurers and differ depending on whether the insurer carries out non-life business and/or life business and whether the insurer is governed by Belgian law or is a branch of an insurer from a third country (Art 15quater of IL; Article 18, 19 \& 27 of the Royal Decree of 22 February 1991).

The solvency requirements may be reduced within certain limits, to take account of reinsurance. The reduction coefficient (maximum 50 percent for non-life business and 15 percent for life business) is based on the reinsurers' share of claims payments. The NBB does not assess the solvency position of the reinsurers participating in the claims payments. Such information is however available to the NBB through the annual reinsurance plans submitted by insurers. (Art 15bis of IL)

Reported data is subjected to an automatic validation test. Data that cannot be validated is analyzed by the supervisors who then decide how to take into account certain elements, e.g.,

- Conditions under which a subordinated loan may be accepted;

- Validity of the unrealized capital gains;

- Contingent claims by way of a call for supplementary contributions;

- $\quad$ Absence of a margin for ILPs; and

- Relevance of the amount of future profits taken into consideration.

The solvency margin is also corrected by taking certain items into account, such as the balance of the unrealized capital gains or losses on assets or the off-balance-sheet commitments to be borne by the insurer.

The solvency margin is subjected to stress tests on the impact on the solvency margin of

- A drop in share prices; and

- A drop in the bond prices or a failure of a debtor (a distinction is made according to the nature of the debtors).

The results of the stress tests and the correction of the solvency margin are added to the quarterly reports, taking account of the unrealized capital gains or losses and off-balancesheet commitments. (Circular D.231).

\section{Eligibility of Capital Resources}

The supervision law specifies the types of capital resource elements that are eligible to meet capital requirements and the limits for different capital items. The criteria are contractual clauses, minimum maturity, the degree of subordination, redemption options, and required documentation.

The Insurance Law specifies the treatment of various types of capital elements, i.e., fully admitted, prior approval for eligibility, restrictions on replacement or redemption. Distinctions are made between life and non-life activities and how capital elements should be segregated in a composite insurer.

\section{Group Solvency}


Solo solvency is supplemented by an annual analysis of the adjusted solvency margin when an insurer is part of a group. A first reporting is done when an insurer participating in an insurance holding company, a reinsurance company or an insurance company of a third country. A second reporting is done when an insurer's parent is an insurance holding company, a reinsurance company or an insurance company of a third country (Art 91ter of IL).

The adjusted solvency margin is calculated using a default method based on consolidated accounts. The group solvency calculation is supported by an inventory of the intra-group relationships and a simplified income statement for each of these relationships.

If a participating insurer does not comply with the adjusted solvency margin, in addition to the interventions that can be done on the solo level, the NBB can also require - where legally possible - to increase reinsurance coverage, or downsizing.

\section{Solvency control levels}

There are two solvency control levels. The Minimum Capital Requirement (MCR), which corresponds to the minimum guarantee fund; and the Prescribed Capital Requirement (PCR) that corresponds to the solvency margin. The MCR equals $1 / 3$ of the solvency margin.

If the coverage ratio $<100$ percent and the margin $<$ minimum guarantee fund, the NBB can withdraw the insurer's license or require the insurer to:

- submit a short-term financing plan;

- take all measures deemed appropriate and necessary to safeguard the interests of policyholders;

- fix the periods within which the shortcomings must be remedied;

- appoint a special auditor to conduct audits at the insurer;

- prohibit certain transactions or restrict the business activities;

- transfer the portfolio or part of it to a third party; and/or

- replacement of the managers, directors or Board representatives.

If the coverage ratio $<100$ percent and margin $\geq$ minimum guarantee fund, the NBB can require the insurer to:

- submit a recovery plan;

- fix the periods within which the shortcomings must be remedied;

- appoint a special auditor to conduct audits at the insurer;

- prohibit certain transactions or restrict the business activities;

- $\quad$ order the portfolio or part of it to be transferred; and

- impose the replacement of the managers, directors or Board representatives.

If 100 percentage < coverage ratio < 200 percentage: taking account of the possible value adjustments, the NBB

- submits the insurer to an in-depth analysis; and/or

- may request more extensive and/or more frequent reporting,

If stress tests are not complied with, the NBB requires an insurer to explain the risks to which it is exposed and how it plans to reduce its exposure to those risks.

The NBB may require a solvency margin in excess of the regulatory minimum, in order to enable an insurer to meet the solvency requirements in the future. The level of this higher solvency margin is determined as part of the financial recovery plan (Art 26, $\$ 2$ of IL).

Insurers that are exempt from the Flashing Light provision (see ICP 14) have to develop an 


\begin{tabular}{|c|c|}
\hline & $\begin{array}{l}\text { ALM model that has to be approved by the NBB. Those insurers have to determine the } \\
\text { economic position over different time horizons, giving the NBB additional information on the } \\
\text { risks and capital required to buffer these risks. } \\
\text { The NBB is engaged with industry participants in conducting forthcoming quantitative impact } \\
\text { studies (QIS) and qualitative assessments in relation to Solvency II policy initiatives. In addition, } \\
\text { as part of its risk assessment tools, the NBB conducts regular stress testing and scenario } \\
\text { analysis on the basis of Solvency II technical specifications to supplement the lack of risk } \\
\text { sensitivity of Solvency I capital requirement calculations. }\end{array}$ \\
\hline Assessment & Partly Observed. \\
\hline Comments & 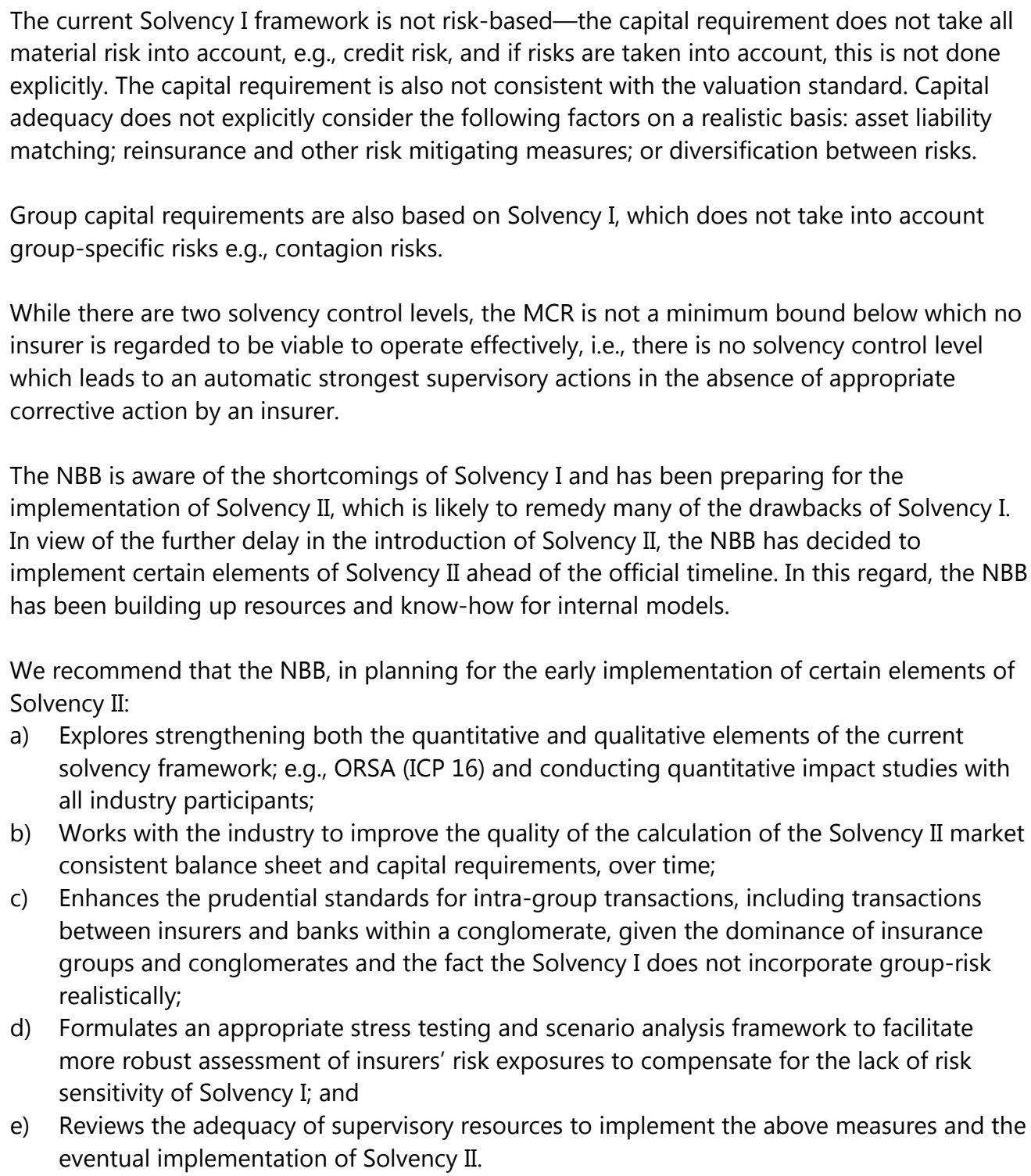 \\
\hline
\end{tabular}




\begin{tabular}{|c|c|}
\hline ICP 18 & $\begin{array}{l}\text { Intermediaries } \\
\text { The supervisor sets and enforces requirements for the conduct of insurance intermediaries, to } \\
\text { ensure that they conduct business in a professional and transparent manner. }\end{array}$ \\
\hline Description & 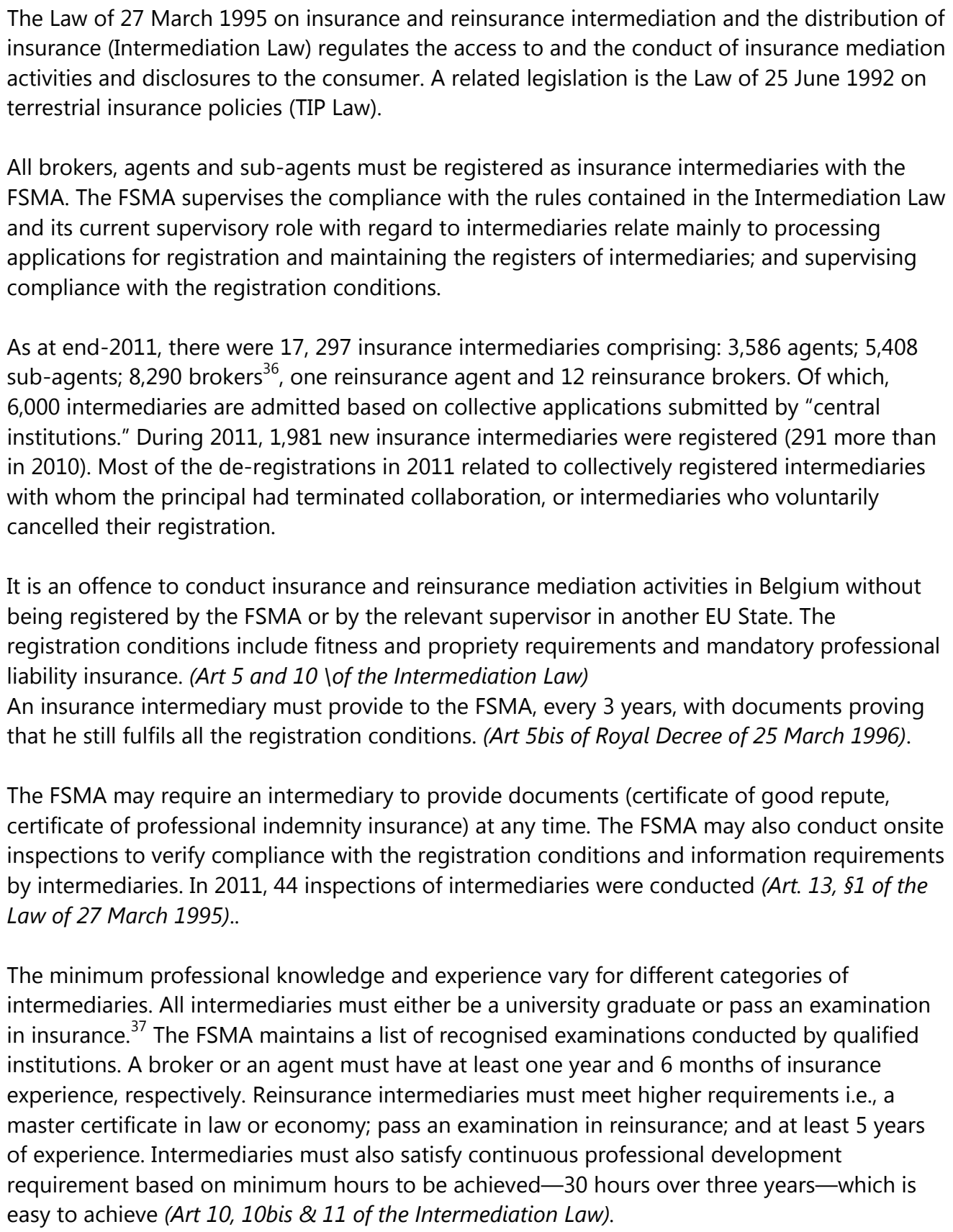 \\
\hline
\end{tabular}

\footnotetext{
${ }^{36}$ Brokers act for the clients while agents act for insurer/reinsurers as their principals. A sub-agent is an intermediary who works under the responsibility of a broker or agent.

${ }^{37}$ The level of qualification is in line with the Insurance Mediation Directive on a European level.
} 
No experience is required of sub-agents but they must work with either a registered agent or broker. The sponsoring agent or broker is responsible for the conduct of the sub-agent. A subagent should indicate to the consumer the name of the insurance intermediary under whose responsibility he works. The minimum continuous professional training hours are lower for sub-agents i.e., 20 hours over three years. There is no requirement for a sub-agent to migrate to agent/broker status within a specified timeframe i.e., they may remain as subagents indefinitely. It is advisable for the authorities to amend the Intermediation Law to impose a time limit for the migration of sub-agents to agents/brokers.

Banks that distribute insurance products are registered as intermediaries with the FSMA. A bank must appoint "responsible persons" with the responsibility to train employees who sell insurance products. These "responsible persons" must meet minimum requirements on experience and knowledge as the persons responsible for the distribution acting for an insurance intermediary. Moreover, persons in contact with the public for the sale of insurance products within banks must have the same degree of qualification as persons in contact with the public within insurance intermediaries.

The FSMA explained that it has not established corporate governance requirements to intermediaries due to the specific structural features of the insurance intermediaries sector in Belgium. Many intermediaries are natural persons (7,209 intermediaries on 30 June 2012) and most of the companies are small businesses. In this regard, the principle of proportionality does not mean exemption for the entire intermediaries sector. Rather, intermediaries should be required to adopt corporate governances practices that are proportionate to the scale and complexities of their operations. In fact, given the large number of intermediaries, the absence of proper self-governance poses significant challenges to the FSMA's limited supervisory resources. It is advisable for the FSMA to establish appropriate regulatory threshold beyond which intermediaries are expected to implement sound corporate governance practices.

The FSMA has concluded that certain aspects of registration regime could be clarified e.g., the content of training programs. In late-2011, the FSMA began talks with intermediaries on updating the rules to make continuing professional education more efficient.

Before the conclusion of an insurance contract and whenever the contract is modified or renewed, an insurance intermediary must disclose certain information to his client: registration particulars, direct or indirect interest of more than 10 percent in any insurer; any insurer (or its parent company) holding more than 10 percent interest in the intermediary; particulars of the Ombudsman. In making a recommendation, an intermediary must inform his client that his client that his advice is founded on an impartial analysis or that he is a tied agent (and, if asked by the client, the name of insurers he is tied with) or that his advice is not based on impartial analysis although he is not a tied agent (in which case he informs the client on his request of the identity of all insurers he can do business with). When a particular information must be communicated to the client on his request, the client must be informed of that right. These rules do not apply for mediation activities concerning insurances of large risks. (Art 12bis of the Intermediation Law)

Client monies to be submitted to insurers received by an intermediary (agents and brokers) are deemed to be received by the insurer. Monies due to clients received by the intermediary from insurers are only considered to be paid once the client has actually received it. Brokers typically do not collect premiums from their clients unless the identity of the potential insurer has been selected. (Art 12 of Intermediation Law and Art 13 of TIP Law)

The FSMA may require any information necessary to supervise intermediaries and regularly assesses the professional ability and integrity of intermediaries (including their management and beneficial owners) based on internal or external information. If the FSMA determines that 


\begin{tabular}{|c|c|}
\hline & $\begin{array}{l}\text { an intermediary is not fulfilling the registration conditions or other requirements, it will require } \\
\text { the intermediaries to rectify the shortcoming within a specified timeframe. Failing which, the } \\
\text { FSMA may take administrative measures, such as the suspension of registration or withdrawal } \\
\text { from the register. In 2010, the registration of } 225^{38} \text { insurance intermediaries was cancelled or } \\
\text { suspended by the FSMA. (Art 13, 13bis of Intermediation Law) } \\
\text { When the FSMA detects unauthorised intermediations activities, it makes preliminary enquiries } \\
\text { and publishes warnings and refers the case to the judicial authority. Persons who conduct } \\
\text { intermediation activities without registration may be subject to judicial prosecution. In } \\
\text { determining whether an activity or a transaction is subject to supervision, the FSMA may } \\
\text { require any person to provide the necessary information. Failure to respond to the information } \\
\text { request may be subject to judicial prosecution. (Art } 15 \text { of Intermediation Law and Art } 78 \text { of SL) } \\
\text { There is currently no regulatory requirement relating to the financial remuneration of } \\
\text { intermediaries. The FSMA intends to adapt the Markets In Financial Instruments Directive } \\
\text { (MiFID), including rules on remuneration, to insurance intermediation. This initiative, when } \\
\text { implemented, will enhance the robustness of the CoB regulation and supervision of insurance } \\
\text { intermediaries. }\end{array}$ \\
\hline Assessment & Largely Observed. \\
\hline Comments & $\begin{array}{l}\text { Although t he registration conditions for intermediaries are clear and transparent, and the } \\
\text { training and qualification requirements imposed by the FSMA complies with the IMD directive } \\
\text { at the European level, there is scope to raise the level of continuous professional development } \\
\text { requirements. The FSMA's supervision of intermediaries focuses mainly on checking } \\
\text { compliance with registrations requirements to limit access by qualified and fit and proper } \\
\text { intermediaries. While the pre-contract information disclosure provides adequate information } \\
\text { on an intermediary's status and relationship with insurers, there is scope for enhancing } \\
\text { disclosure on potential conflict of interest, particularly relating to remuneration arrangements. } \\
\text { The FSMA conducts on-site inspections of intermediaries and has withdrawn or suspended the } \\
\text { registrations of intermediaries who failed to meet its requirements. The legal framework } \\
\text { provides protection for clients monies handled through intermediaries. } \\
\text { To effectively supervise a large numbers of intermediaries with limited resources, it is advisable } \\
\text { that the FSMA develops an appropriate risk-based approach, supported by explicit and } \\
\text { proportionate corporate governance requirements for intermediaries. The FSMA's proposal to } \\
\text { adapt MiFID } 2 \text { for insurance intermediation will improve observance of ICP 18, when the } \\
\text { measures are implemented. In addition, it is advisable: } \\
\text { a) For the FSMA to review the effectiveness of the current continuous professional } \\
\text { development requirements and to establish appropriate regulatory threshold beyond } \\
\text { which intermediaries are expected to implement sound corporate governance practices; } \\
\text { and } \\
\text { b) For the authorities to amend the Intermediation Law to impose a time limit for the } \\
\text { migration of sub-agents to agents/brokers. }\end{array}$ \\
\hline
\end{tabular}

\footnotetext{
${ }^{38}$ Include the automatic expiry of the registration of 14 insurance intermediaries on grounds of bankruptcy.
} 


\begin{tabular}{|c|c|}
\hline ICP 19 & $\begin{array}{l}\text { Conduct of Business } \\
\text { The supervisor sets requirements for the conduct of the business of insurance to ensure } \\
\text { customers are treated fairly, both before a contract is entered into and through to the point at } \\
\text { which all obligations under a contract have been satisfied. }\end{array}$ \\
\hline Description & 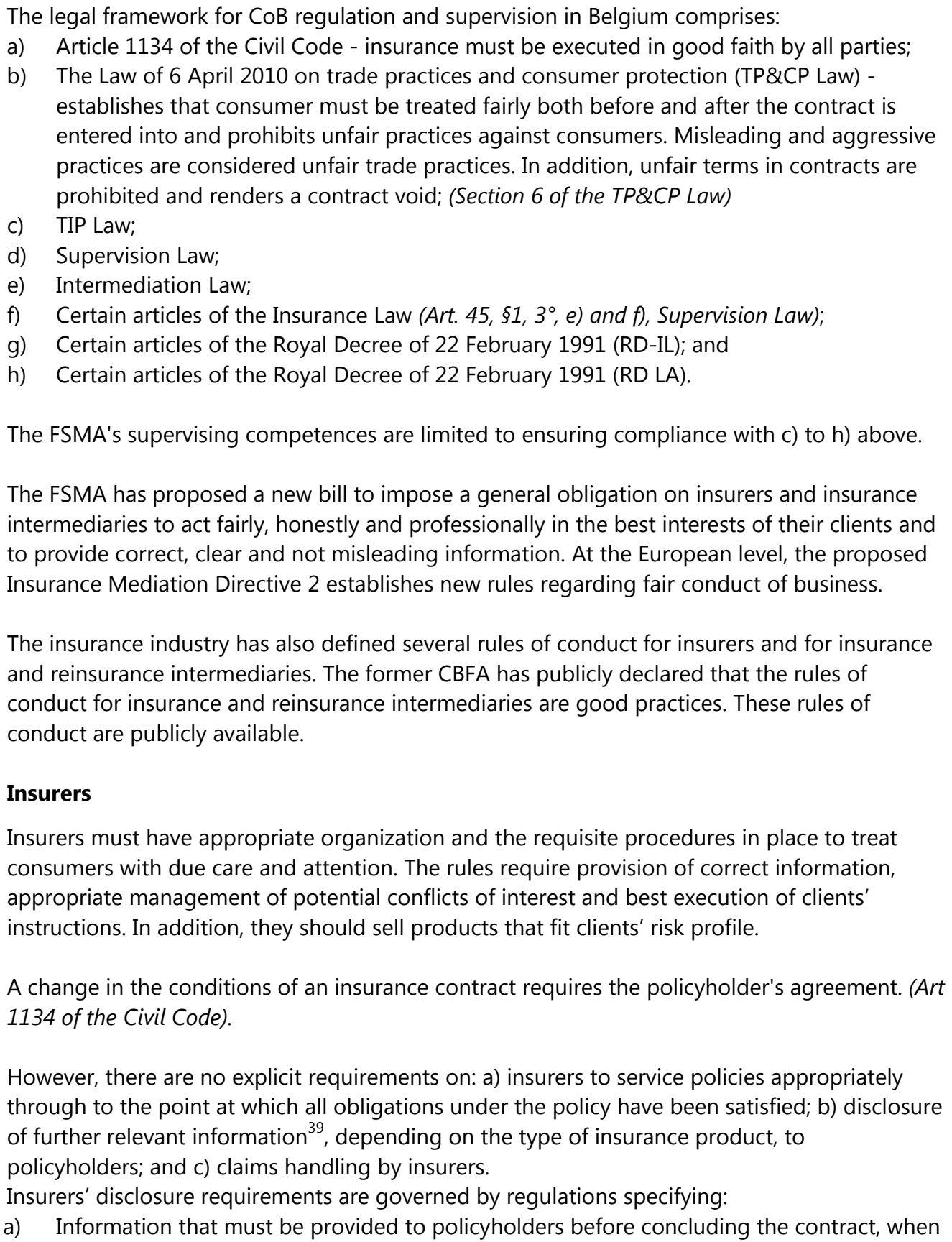 \\
\hline
\end{tabular}

\footnotetext{
${ }^{39}$ Further information regarding life insurance and annuities should, at a minimum, include: participation rights in surplus funds; the basis of calculation and state of bonuses; the current cash surrender value; premiums paid to date; and report on investment for investment-linked policies. (ICP 19.8.8)
} 
concluding the contract and during the life of the contract. (Art 15 of RD-IL)

b) Information to be disclosed for specific life insurance policies (Art 8, 19, 20, 23, 60, 61, 62, 72 and 73 of $R D-L A$ )

All insurers must appoint one or more compliance officers in order to ensure compliance with the rules of conduct. The appointment of compliance officers by insurers is subject to approval of the FSMA. To demonstrate that they have the necessary knowledge, compliance officers must pass an examination at a training centre recognized by the FSMA. Top management of institutions must cultivate a compliance culture a priority within their organizations. (Art 87bis of Supervision Law.)

In 2011, the FSMA drafted a Circular on residential fire insurance, in response to the result of a survey completed in 2010 indicating omissions and infringements by some insurers in the application of the law. The conclusions of this survey were communicated to insurers and consultation on the circular was in progress at the time of assessment.

\section{Intermediaries}

Intermediaries are obliged to provide information to clients: on paper or in a medium accessible to the clients; clearly, exactly and understandable to the client; in one of the official languages in Belgium. The information can be given orally when asked by the client when the insurance contract has immediate effect. The same rules are applicable when the services are provided by phone. (Art 12quater of the Intermediation Law and Law of 24 August 2005 concerning the distance marketing of consumer financial services and the directive on privacy and electronic communications.)

Intermediaries must also make certain pre-contract disclosures to their clients (refer to ICP 18).

\section{Financial and Insurance Products}

The FSMA's objective of effective product supervision is to help ensure that financial products are understandable, safe, useful and cost-transparent. It cannot be assumed that consumers have sufficient knowledge and skills to understand information disclosed by financial entities and that they are prepared to consult the information that is available. It is, therefore, necessary to intervene at the product development stage to provide incentives for simpler products or products that better meet the needs of the target clientele group.

Product supervision covers the quality of the information disclosed and advertising material and compliance with the regulations governing financial products. Specifically for insurance products, the FSMA oversees the provision of pre-contractual information and the contractual terms and conditions for insurance products.

Various laws provide specific provisions to protect certain types of insurance customers. For example:

a) Prohibition against discrimination, including premium ratings (Law of 10 May 2007 for combating different forms of discrimination; and Law of 10 May 2007 for combating discrimination between women and men and Article 12 of RD-IL);

b) Right of chronically diseased people and disabled people who are less than 65 years of age to conclude a sickness insurance (Art 138bis of TIP Law)

c) Opportunity for people presenting major health risks to conclude residual balance insurance when they conclude a mortgage loan. (Law of 21 January 2010). 
Recognizing that Belgium is the largest market for structured products in Europe ${ }^{40}$, the first milestone in product supervision achieved by the FSMA is the introduction of a moratorium on "particularly complex" structured products, which came into effect in August 2011. Financial institutions that distribute structured products in Belgium signed on voluntarily to the moratorium. To maintain a level playing field, the FSMA does not distinguish structured product based on their "wrappings" i.e., the moratorium adopts a cross-sectoral approach and applies to collective investment schemes, investment instruments, ILPs, or a deposit.

The moratorium applies to the distribution to retail investors of structured products that are considered as "particularly complex" based on four criteria:

a) Accessibility of the underlying assets - i.e., retail investors can follow the relevant market information e.g., instrument admitted to a regulated market, or market indexes that have sufficient track record and transparency. A portfolio of assets such as a basket of shares should meet certain conditions. Certain assets are considered inaccessible, such as credit default swaps, commodities (other than gold) and speculative contracts;

b) No overly complex strategies - strategies that are considered too complex include: use of a "teaser," particularly products with a fixed return that does not apply throughout their lifetime; where the investor may incur a loss but do not participate in the increase in value of the underlying; where a minimal change in the performance of the underlying assets can have a disproportionate impact on the principal or returns; and products that are distributed as capital-protected even though the built-in protection is conditional;

c) No overly complex calculation formulas; and

d) Sufficient transparency on all costs incurred by the investor, name of the issuer (the name of the product may not make an (implicit) reference to the distributor); market value of the product (quarterly); and important changes in the risk profile or the value of the product.

The FSMA considers that its product supervision has led to structured products being simplified and it is easier to compare across new structured products that came into the market after the moratorium. While fewer structured products are being launched, it is unclear to what extent this development is a consequence of the crisis or of the moratorium.

\section{Privacy protection and Financial education}

Intermediaries are required to protect the personal information of their clients under the privacy law, which imposes various obligations on any person responsible for processing data, including: informing natural persons whose data are being processed; granting such persons access to their data; and permitting them to correct or withdraw data that are incorrect or processed in an illicit manner. (Law of 8 December 1992 on the protection of privacy with regard to the processing of personal data.)

\footnotetext{
${ }^{40}$ In 2010, investments in structured products amounted to $€ 87.2$ billion (for a population of 10.8 million), representing one-third of the total amount deposited in regulated savings accounts ( $€ 200$ billion in regulated savings deposits and approximately $€ 35$ billion in term deposits).

Comparison with regional jurisdictions: in France there was in 2010 a total of $€ 85.6$ million (population: 64.7 million), in Germany $€ 142.7$ million (81.8 million), in Italy $€ 220.1$ million (60.3 million) and in the UK €60.2 million (62 million).
} 


\begin{tabular}{|c|c|}
\hline & $\begin{array}{l}\text { The FSMA is tasked with contributing to better financial education of savers and investors. The } \\
\text { FSMA is developing an action plan for improving the financial knowledge of Belgians. It } \\
\text { intends to mobilize and coordinate with and supporting relevant external organizations active } \\
\text { in the field of financial education. It has also developed a portal for the public and teachers, } \\
\text { drawing attention to the various materials available for financial education. } \\
\text { The FSMA answers consumer questions relating to financial topics and alerts the public and } \\
\text { the judicial authorities when it identifies unauthorized financial products being offered } \\
\text { unlawfully. In 2011, the FSMA dealt with } 530 \text { written requests for information and a large } \\
\text { number of telephone requests. } \\
\text { Dispute resolution } \\
\text { Belgian insurers have drawn up the "Code of conduct for handling complaints within insurance } \\
\text { companies," which is available on the website of Assuralia, the insurance association of } \\
\text { Belgium. It contains provisions on the timely and fair treatment of complaints. } \\
\text { The FSMA investigates complaints in its capacity as supervisor and takes action, where } \\
\text { necessary. However, the FSMA is not competent to mediate between a financial institution and } \\
\text { a client. Insurance and reinsurance intermediary are required to join and cooperate with the } \\
\text { Belgian Insurance Ombudsman. When an insurance intermediary refuses to give the requested } \\
\text { information to the Ombudsman, his registration can be withdrawn. A Protocol has been signed } \\
\text { between the FSMA and the Ombudsman to collaborate and to exchange information on } \\
\text { intermediaries. The FSMA is a member of the Supervisory Board of Insurance Ombudsman (Art } \\
10 \text { of the Intermediation Law). }\end{array}$ \\
\hline Assessment & Largely observed. \\
\hline Comments & $\begin{array}{l}\text { The current regulatory regime on CoB focuses on prohibition against unfair and misleading } \\
\text { practices. The implementation of the voluntary moratorium of structured products that are } \\
\text { considered as "particularly complex" in August } 2011 \text { is a commendable supervisory initiative. } \\
\text { The emerging international best practices are to promote fair treatment of customers that are } \\
\text { an integral part of business culture of insurers and intermediaries. In this regard, the FSMA has } \\
\text { proposed amendments to the Supervision Law to impose a general obligation on insurers and } \\
\text { insurance intermediaries to act fairly, honestly and professionally in the best interests of their } \\
\text { clients and provide correct, clear and not misleading information. The proposed adaptation of } \\
\text { MiFID } 2 \text { to insurance meditation will enhance CoB requirements. } \\
\text { The authorities is advised to strengthen the CoB regime by: } \\
\text { a) Implementing the proposed amendments to the Supervision Law and the MiFID } 2 \\
\text { requirements to better ensure fair treatment of clients; } \\
\text { b) Empowering the FSMA to issue enforceable rules on: the handling of claims and policy } \\
\text { servicing by insurers; and fact-finding of client's needs and financial circumstances as } \\
\text { basis for financial advice; and } \\
\text { c) Ensuring that the FSMA is adequately resourced to supervise the CoB of insurers and } \\
\text { intermediaries effectively. }\end{array}$ \\
\hline
\end{tabular}




\begin{tabular}{|c|c|}
\hline ICP 20 & $\begin{array}{l}\text { Public Disclosure } \\
\text { The supervisor requires insurers to disclose relevant, comprehensive and adequate information } \\
\text { on a timely basis in order to give policyholders and market participants a clear view of their } \\
\text { business activities, performance and financial position. This is expected to enhance market } \\
\text { discipline and understanding of the risks to which an insurer is exposed and the manner in } \\
\text { which those risks are managed. }\end{array}$ \\
\hline Description & 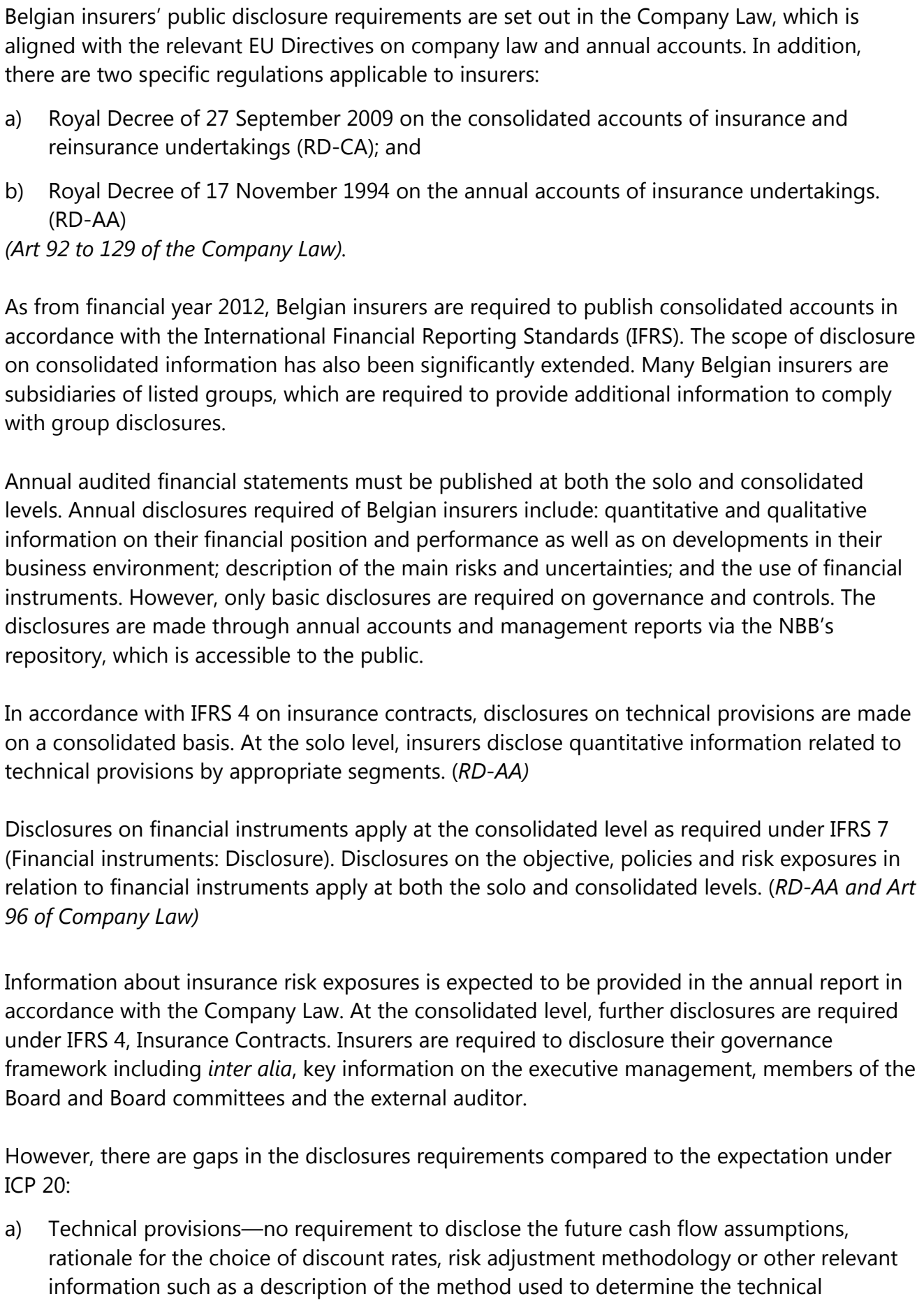 \\
\hline
\end{tabular}




\begin{tabular}{|c|c|}
\hline & $\begin{array}{l}\text { provisions; } \\
\text { b) Capital adequacy. At the consolidated level, the application of IFRS will strengthen } \\
\text { disclosures on capital adequacy (e.g., objectives, policies and processes for managing } \\
\text { capital as well as observance of capital requirements); } \\
\text { c) No requirement to disclose enterprise risk management including asset-liability } \\
\text { management; } \\
\text { d) Segmented financial performance-only some information is to be provided in the notes } \\
\text { to the annual accounts at the solo level. At the consolidated level, the application of IFRS } \\
\text { will enhance disclosures; and } \\
\text { e) Company profile-only basic information is disclosed under the Company Law. }\end{array}$ \\
\hline Assessment & Partly observed. \\
\hline Comments & $\begin{array}{l}\text { The current disclosure regime in Belgium focuses on the financial position and performance of } \\
\text { insurers and there are significant gaps in the disclosures on: technical provisions, risk } \\
\text { management and exposures, details of performance and capital adequacy. The application of } \\
\text { IFRS as from financial year } 2012 \text { has improved the disclosures made in consolidated accounts. } \\
\text { The impending implementation of Solvency II will bring the disclosure regime in line with } \\
\text { international best practices. } \\
\text { The authorities are advised to address the significant gaps in the disclosure requirements } \\
\text { identified. }\end{array}$ \\
\hline ICP 21 & $\begin{array}{l}\text { Countering Fraud in Insurance } \\
\text { The supervisor requires that insurers and intermediaries take effective measures to deter, } \\
\text { prevent, detect, report and remedy fraud in insurance. }\end{array}$ \\
\hline Description & $\begin{array}{l}\text { Insurance-related frauds are covered by general Belgian criminal legislation and subject to } \\
\text { criminal proceedings. Such frauds include swindle, forgery, and breach of confidence. The rules } \\
\text { regarding punishable attempts and punishable complicity apply. There are also contractual } \\
\text { sanctions for deliberate concealment, deliberate damage, and deceptive intent. (Article } 496 \& \\
193-214 \text { of the Penal Code and the Law of } 25 \text { June } 1992 \text { on non-marine insurance policy) } \\
\text { The insurance industry has taken a number of self-regulatory measures to counter fraud, such } \\
\text { as training programmes, industry databases (e.g., Datassur), }{ }^{41} \text { and a new code of conduct was } \\
\text { introduced by Assuralia in September } 2012 \text { to replace the agreement of } 1 \text { January } 2000 \text {. } \\
\text { Insurers adopting the code must implement policies to counter fraud. In addition, a protocol } \\
\text { concerning insurance fraud prevention was agreed by organizations of insurers and } \\
\text { intermediaries (Assuralia, FEPRABEL, FVF and BVVM) including the establishment of a } \\
\text { Professional Board to examine fraud typologies. It was agreed that illegal activities are to be } \\
\text { reported to the NBB or the FSMA, in their respective fields of competencies. } \\
\text { As part of its CoB supervision, the FSMA checks compliance with rules aimed at protecting } \\
\text { financial consumers, which include the illegal offer of insurance products. }\end{array}$ \\
\hline
\end{tabular}

\footnotetext{
${ }^{41}$ An economic interest grouping that manages its members' data and information, including claims history, unpaid insurance premiums, fraud, stolen cars etc.
} 


\begin{tabular}{|c|c|}
\hline & $\begin{array}{l}\text { The NBB and the FSMA understands and are alert to the types of fraud that may occur in the } \\
\text { insurance industry. Supervisory attention for fraud is part of the assessments relating to } \\
\text { insurers' governance/risk management, compliance and internal audit functions. External } \\
\text { auditors assume an important (early) warning function as part of their whistle blowing } \\
\text { obligations. } \\
\text { Insurers must submit to their Boards, external auditors and the NBB a report on their internal } \\
\text { control system every year (ICP 8), which covers fraud risk. This report provides inputs to the } \\
\text { NBB's assessment of measures taken by insurers to deter, prevent, detect, report and remedy } \\
\text { fraud in insurance insurers. Insurers should also implement an integrity policy, which focuses } \\
\text { on the prevention of the use of the financial system for money laundering (ICP 21) and fiscal } \\
\text { fraud. Insurers' compliance functions are responsible for monitoring transactions or } \\
\text { relationships (including those with intermediaries) that are not in line with the integrity policy } \\
\text { and report to the appropriate levels. (Circular CBFA_2009_26 dd. } 24 \text { Jun 2009, Communication } \\
\text { D. } 207 \text { of } 30 \text { November } 2001 \text { and Circular PPB/D. 255) } \\
\text { Insurers and insurance intermediaries are not legally obliged to institute legal proceedings or } \\
\text { inform the NBB or the FSMA. Nonetheless, a private detective employed by an insurer is } \\
\text { compelled to report offences to the public prosecutor. Based on complaints received, the NBB } \\
\text { or the FSMA may detect criminal offences or frauds. Such cases may be referred to the Crown } \\
\text { prosecutor for consideration. Likewise, other authorities may inform the NBB or the FSMA of } \\
\text { offences under financial sector laws. Such information exchanges have been infrequent in } \\
\text { practice. }\end{array}$ \\
\hline Assessment & Observed. \\
\hline Comments & $\begin{array}{l}\text { While there is no specific legislation on insurance fraud, the general criminal law adequately } \\
\text { addresses fraudulent conduct relating to insurance, which are subject to criminal proceedings. } \\
\text { Supervisory attention for fraud is part of the assessments relating to governance/risk } \\
\text { management, compliance and internal audit functions (where applicable) of insurers. The } \\
\text { insurance industry has taken measures to counter fraud such as training programs, sharing } \\
\text { information via databases and a new code of conduct concerning insurance fraud prevention. } \\
\text { The NBB and FSMA may cooperate, coordinate and exchange information relating to } \\
\text { insurance frauds with other competent authorities, including foreign authorities. } \\
\text { The authorities are advised to empower the NBB and the FSMA to issue enforceable rules } \\
\text { requiring insurers and intermediaries to report insurance frauds. }\end{array}$ \\
\hline ICP 22 & $\begin{array}{l}\text { Anti-Money Laundering and Combating the Financing of Terrorism } \\
\text { The supervisor requires insurers and intermediaries to take effective measures to combat } \\
\text { money laundering and the financing of terrorism. In addition, and the supervisor takes } \\
\text { effective measures to combat money laundering financing of terrorism. }\end{array}$ \\
\hline Description & $\begin{array}{l}\text { The authorities systematically forge dialogue with professional associations in the financial } \\
\text { sector, as inputs to the sector-specific AML/CFT regulations and guidance. They also receive } \\
\text { reports on AML/CFT submitted by compliance officers on attempts of money laundering } \\
\text { identified and potential risks. The annual reports of the Financial Intelligence Unit (CTIF) are } \\
\text { also a useful source of information. }\end{array}$ \\
\hline
\end{tabular}




\begin{tabular}{|c|c|}
\hline & $\begin{array}{l}\text { Taking into account the new FATF Recommendations of February 2012, and in preparation for } \\
\text { the 4th Mutual Evaluation by the FATF in September 2014, reflection is currently underway } \\
\text { within the NBB with the aim to improve the knowledge of, and the consideration to the risk, } \\
\text { both on the regulation/guidance and supervision of insurers' compliance with their AML/CFT } \\
\text { obligations. } \\
\text { The former CBFA adopted a regulation on the obligations of financial institutions, pursuant to } \\
\text { the AML/CFT Law of } 11 \text { January } 1993 \text {. In addition, it published a circular on the obligations of } \\
\text { customer due diligence covering, inter alia, life insurers. (Art } 38 \text { of the AML/CFT Law, } \\
\text { Regulation of } 23 \text { February } 2010 \text { and Circular CBFA_2011_09 of } 1 \text { March 2011). } \\
\text { The above regulation and circular remain applicable to all life insurers and intermediaries. In } \\
\text { future, the NBB or the FSMA will adopt separate regulations and/or circulars for the financial } \\
\text { institutions under their respective supervision. The CTIF provides feedback to the NBB and the } \\
\text { FSMA on suspicious transactions reported. } \\
\text { The NBB integrates its AML/CFT supervision in its wider prudential supervision framework, i.e., } \\
\text { through both off-site monitoring and onsite inspection. While no onsite AML-CFT inspection } \\
\text { was conducted in } 2011, \text { three were undertaken in the first half of } 2012 \text {, of which one was } \\
\text { specifically focused on AML-CFT. }\end{array}$ \\
\hline Assessment & Observed. \\
\hline Comments & $\begin{array}{l}\text { The NBB and FSMA are aware of the money laundering and terrorism financing risks of the } \\
\text { insurance industry and have effective mechanisms to cooperate, coordinate and exchange } \\
\text { information with both domestic and foreign supervisors/FIUs. The authorities are reviewing the } \\
\text { current AML-CFT regime to take account of the new FATF Recommendations of February } \\
2012 \text {. } \\
\text { The authorities should periodically reconsider whether or not non-life insurance should be } \\
\text { covered by the AML/CTF regime in Belgium. }\end{array}$ \\
\hline ICP 23 & $\begin{array}{l}\text { Group-wide Supervision } \\
\text { The supervisor supervises insurers on a legal entity and group-wide basis. }\end{array}$ \\
\hline Description & $\begin{array}{l}\text { Chapter VIIbis of the Insurance Law establishes the legal framework for group-wide } \\
\text { supervision in Belgium. } \\
\text { The NBB shall exercise supplementary supervision over an insurer: with participations }{ }^{42} \text { in at } \\
\text { least one other insurer or reinsurer; is a subsidiary of an insurance holding company }{ }^{43} \text {; a }\end{array}$ \\
\hline
\end{tabular}

\footnotetext{
42 Participation is defined as: the holding, directly or indirectly, of rights in another company to enable an insurer to influence the management strategy of the company, or the holding of $20 \%$ or more of the voting rights or capital of the company. (Art 91bis $6^{\circ}$ of IL)

${ }^{43}$ Insurance holding company: a parent company the main business of which is to hold participations in subsidiary companies, which are exclusively or mainly insurers or reinsurers, and not being a mixed financial holding company. (Art 91bis $9^{\circ}$ of IL)
} 
subsidiary of a non-EEA insurer/reinsurer; or a subsidiary of a mixed-activity insurance holding. ${ }^{44}$ Pursuant to the Helsinki protocol, the NBB has identified all Belgian insurance groups subject to supplementary supervision. The list of insurance groups is regularly updated to facilitate establishment of supervisory colleges (ICP25) (Art 91ter of IL).

Belgian insurers which are members of a financial conglomerate are also subject to supplementary supervision. The NBB can extend the scope of supplementary supervision to include companies outside the financial sector (Article 91octies decies of IL).

The scope of supplementary supervision covers: related companies of a Belgian insurer; participating companies in the Belgian insurer; and related companies of a participating company in the Belgian insurer. Thus, supplementary supervision is applicable to both regulated and non-regulated entities as well as operating and non-operating entities within a group. Specifically, the NBB has power to require non-regulated entities to provide all relevant information for exercising supplementary group supervision and conduct onsite inspections of such entities. Such non-regulated entities, in the context of Belgium, are generally real estate companies, asset management companies or service providers (Art 91ter $\$ 3$ and 91octies decies of IL).

The NBB, in cooperation with other involved supervisors as necessary, identifies the scope of the group subject to group-wide supervision. It may decide, on a case-by-case basis, not to include an entity in the scope of supplementary supervision, if: it is of negligible interest or the inclusion would be inappropriate or misleading; with respect to the objectives of the supplementary supervision (Art 91ter $\$ 5$ and $\$ 4$ of IL).

For determining the scope of a group, due consideration is also given to contractual obligations, intra-group transfers, risk exposures and concentrations or intra-group transactions. However, the NBB has not experienced such cases so far. The lack of legal authority and/or supervisory power over particular entities has no impact on the scope of group-wide supervision. For example, in calculating the group solvency ratio, participations in entities for which there is no information available are deducted from the own funds (Royal decree l.1.1.4 d).

The NBB has the flexibility to update the scope of supervision to reflect changes in group structures. It has the discretion to consider all material and relevant changes in or outside the group, or the macro-economic context, and adapt the scope of group-wide supervision if necessary. In addition, as a group supervisor, it has the power to approve significant changes in the group structure e.g., portfolio transfer or changes in control.

One of the authorisation criteria is that the structure of a group has to be sufficiently transparent to allow an effective group-wide supervision. There was a recent case where the NBB asked a group to simplify its structure to eliminate double gearing of own funds via mutual funding. (Art 8 of IL)

Insurance groups must submit to the NBB, upon request, any data and information relevant for supervision, including information on non-regulated entities. The NBB may also request for such information directly from the other group entities (Art 91quinquies and 91sexies of IL.).

\footnotetext{
${ }^{44}$ Mixed-activity insurance holding company is a parent company other than: an insurer or a reinsurer; an insurance holding company or a mixed financial holding company (of a financial conglomerate) which includes at least one insurer/reinsurer.
} 


\begin{tabular}{|c|c|}
\hline & $\begin{array}{l}\text { The group-wide supervision framework provides for the supervision of: } \\
\text { a) The group's risk management and internal controls, including adequate reporting and } \\
\text { accounting systems, which should allow the insurer/group to provide the necessary } \\
\text { information for the purpose of supervision; (Art 91quater of IL) } \\
\text { b) Intra-group transactions i.e., loans, guarantees and off-balance-sheet transactions, } \\
\text { elements eligible for the solvency margin, investments, reinsurance and retrocession } \\
\text { operations and cost contribution agreements; and (Art 91octies of IL) } \\
\text { c) Group (adjusted) solvency margin, on an aggregate basis, in relation to insurers' activities } \\
\text { and the activities of its related companies. }{ }^{45} \text { (Art 91nonies of IL) } \\
\text { However, the group-wide supervision framework does not cover market conduct in a group } \\
\text { context. } \\
\text { The NBB is empowered to conduct onsite inspection of an insurer and its subsidiaries; and the } \\
\text { parent company of an insurer and its subsidiaries. Where, the NBB wishes to inspect an } \\
\text { insurer's subsidiary/parent (and its subsidiary) company located in EEA, it shall ask the host } \\
\text { supervisor to conduct the inspection or authorize the NBB to do so. For non-EEA host } \\
\text { supervisors, this could be agreed in accordance with bilateral MoUs (Art 91septies of IL). } \\
\text { The NBB strives to adopt an effective and efficient group-wide supervision framework through: } \\
\text { continuous risk assessment of the group based on its Scorecard system (ICP9), analyses of } \\
\text { periodic reports such as consolidated financial statements, adjusted solvency margins, intra- } \\
\text { group transactions and fit and proper assessments of management. It has authority to inspect } \\
\text { all group entities. The nature, scale and complexity of insurance groups are taken into } \\
\text { consideration. }\end{array}$ \\
\hline Assessment & Largely observed. \\
\hline Comments & $\begin{array}{l}\text { The supplementary supervision of insurance groups in Belgium is shaped by EU Directive and } \\
\text { facilitated by a structured coordination framework at the EU level organized by EIOPA. The } \\
\text { NBB has adequate powers and flexibility to determine the scope of insurance groups as well as } \\
\text { to supervise and take appropriate measures against both regulated and non-regulated entities } \\
\text { within a group. The NBB is actively involved in supervisory colleges, both as a home and host } \\
\text { supervisor (ICP 25). } \\
\text { However, there are no group-wide market conduct requirements. There is also scope for } \\
\text { establishing consistent supervisory processes for group supervision e.g., in reporting intra- } \\
\text { group transactions. Although the NBB has concluded supervisory cooperation agreements } \\
\text { with other insurance supervisors, there is scope for improvement. To this end, the supervisory } \\
\text { colleges are taking up this work under the aegis of EIOPA. } \\
\text { The implementation of Solvency II will enhance Belgium's observance with ICP 23. It is } \\
\text { important that the NBB carefully plan for adequate supervisory resources to supervise } \\
\text { insurance groups, especially the complex cross-border groups that are domestic SIFIs. }\end{array}$ \\
\hline
\end{tabular}

\footnotetext{
${ }^{45}$ A group need not calculate an adjusted solvency margin if it is a related company of another participating Belgian insurer/reinsurer and is taken into account in the calculation of the adjusted solvency margin of that insurer/reinsurer.
} 


\begin{tabular}{|c|c|}
\hline ICP 24 & $\begin{array}{l}\text { Macroprudential Surveillance and Insurance Supervision } \\
\text { The supervisor identifies, monitors and analyses market and financial developments and other } \\
\text { environmental factors that may impact insurers and insurance markets and uses this } \\
\text { information in the supervision of individual insurers. Such tasks should, where appropriate, } \\
\text { utilize information from, and insights gained by, other national authorities. }\end{array}$ \\
\hline Description & 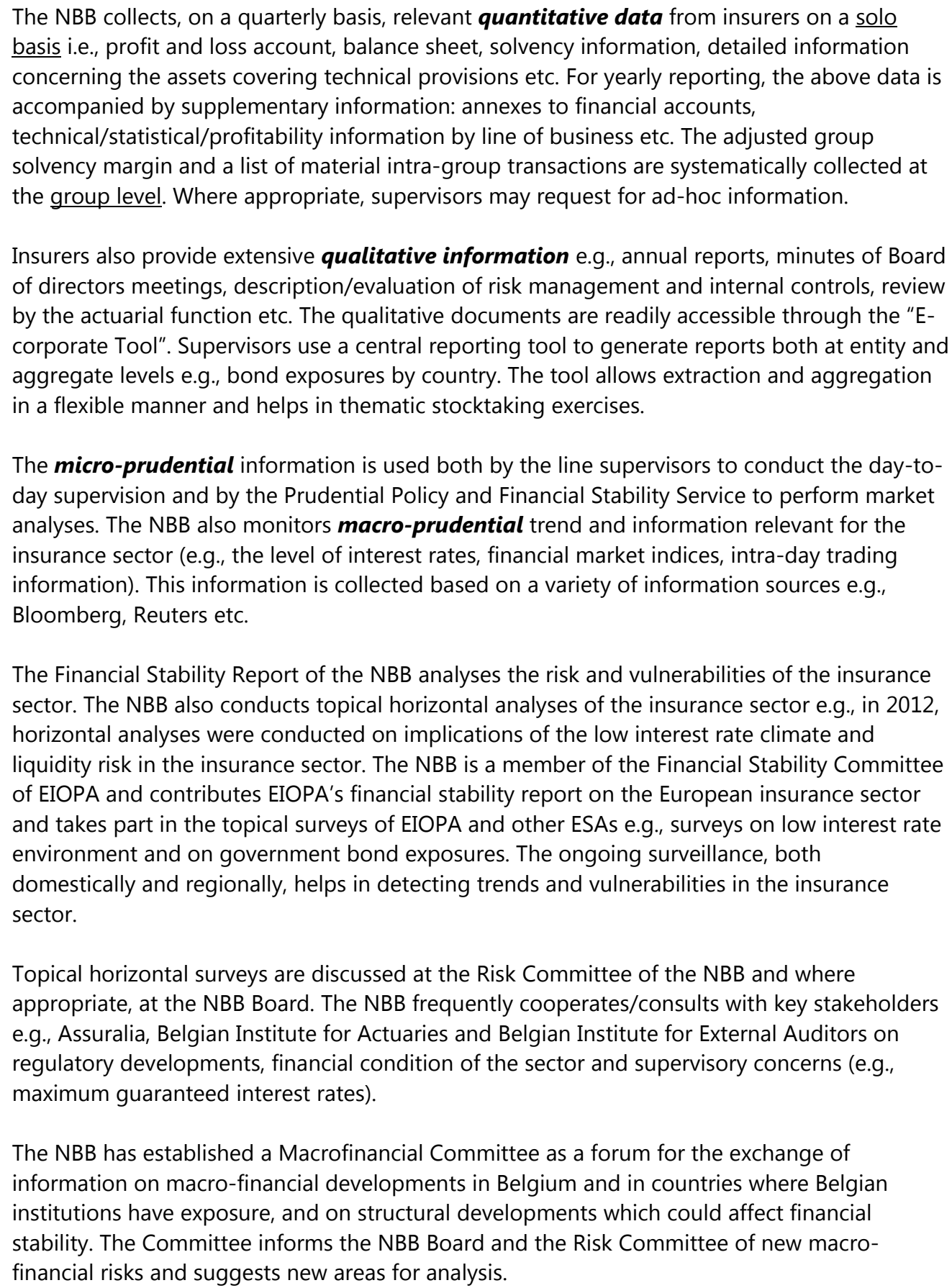 \\
\hline
\end{tabular}




\begin{tabular}{|c|c|}
\hline & 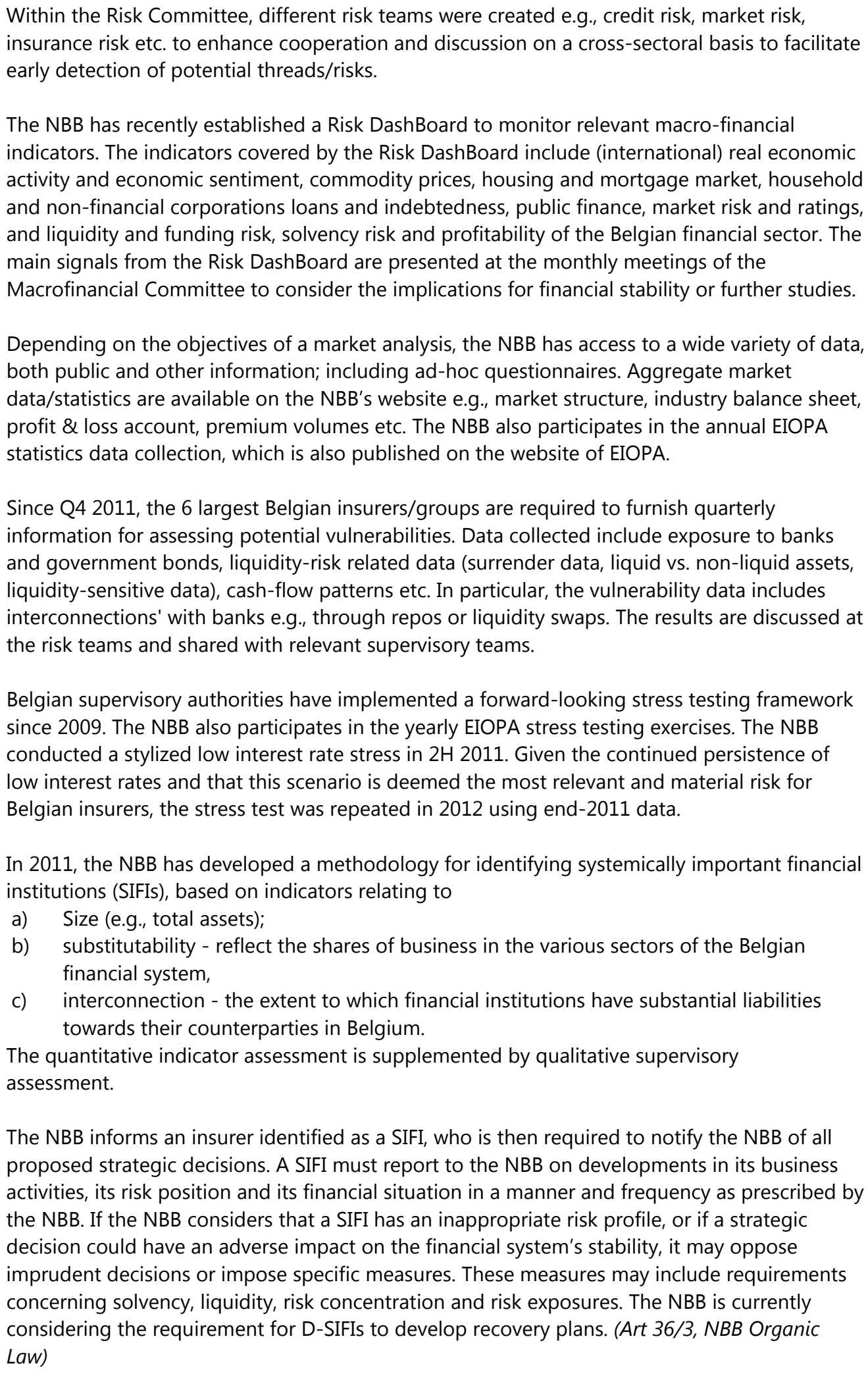 \\
\hline & \\
\hline
\end{tabular}




\begin{tabular}{|c|c|}
\hline Comments & $\begin{array}{l}\text { As the central bank and prudential supervisor, the NBB is well placed in achieving effective } \\
\text { macroprudential surveillance. It collects extensive quantitative and qualitative information } \\
\text { quarterly, complemented by ad-hoc questionnaires, if necessary. Its Macrofinancial Committee } \\
\text { serves as a forum for the exchange of information on macro-financial developments in } \\
\text { Belgium and in countries where Belgian institutions have exposure. The Risk Committee } \\
\text { oversees cross-sectoral risk analyses by risks areas to facilitate early detection of potential } \\
\text { systemic threads/ risks. The NBB participates in the yearly EIOPA stress testing exercises and } \\
\text { conducts its own stress tests of the Belgian insurance sector. } \\
\text { Given that macro-prudential surveillance is a nascent development, the NBB plans to regularly } \\
\text { review the integration of macro-prudential analyses and assessments into its micro-prudential } \\
\text { supervision to identify further refinements. }\end{array}$ \\
\hline ICP 25 & $\begin{array}{l}\text { Supervisory Cooperation and Coordination } \\
\text { The supervisor cooperates and coordinates with other relevant supervisors and authorities } \\
\text { subject to confidentiality requirements. }\end{array}$ \\
\hline Description & $\begin{array}{l}\text { The NBB is empowered to exchange information as part of its group supervision framework. } \\
\text { The legal basis is the EU Insurance Group Directive }{ }^{46} \text { transposed into the Insurance law and the } \\
\text { Helsinki Protocol. }{ }^{47} \text { (Art 91bis to 91octies of IL). } \\
\text { Supervisory College } \\
\text { Solvency II envisages the establishment of supervisory colleges for all insurance groups. Paving } \\
\text { the way for the coming into force of Solvency II, supervisory colleges are already set up where } \\
\text { necessary, and listed on the EOIPA website. The NBB attends nine colleges of supervisors. It } \\
\text { chairs three of those colleges as the home supervisor (Ageas, KBC Insurance and Belfius } \\
\text { Insurance) and takes part in the others as the host supervisor (AXA, ING, and Generali). For two } \\
\text { other insurance groups, the creation of a college of supervisors with the NBB as the home } \\
\text { supervisor is currently under consideration. In the case of smaller groups, cross-border } \\
\text { coordination operates mainly on a bilateral basis via Coordination Committees. } \\
\text { The Helsinki Protocol states that the cooperation between supervisors should be facilitated by } \\
\text { a Coordination Committee and that one lead supervisor should carry out most or all the tasks } \\
\text { of supplementary supervision. CEIOPS (now EIOPA) has established guidelines to implement } \\
\text { the Protocol: Guidelines for Coordination committees in the framework of the Insurance Group } \\
\text { Directive (2005); and Statement of the Role of the Lead Supervisor. Going forward, the Solvency } \\
\text { II Directive will replace the current framework. EIOPA has drafted a template on coordination } \\
\text { arrangements. As Solvency II has not come into effect, the arrangements have not been signed } \\
\text { but will be finalised when the Omnibus II Directive is passed (Art } 248 \text { (1) of Solvency II } \\
\text { Directive). } \\
\text { To better understand the risk profiles of Belgian insurance groups, the NBB identifies } \\
\text { supervisors of insurers outside of the EU that might have a material contribution to the risks of } \\
\text { the groups. It assesses the equivalence of third countries' confidentiality requirements or verify }\end{array}$ \\
\hline
\end{tabular}

\footnotetext{
${ }^{46}$ Directive 98/78/EC of the European Parliament and of the Council on the supplementary supervision of insurance undertakings in an insurance group.

${ }^{47}$ The Protocol relate to the collaboration of the supervisory authorities of EU member states pursuant to Directive 98/78/EC on the supplementary supervision of undertakings in an insurance group of 11 May 2000.
} 
that they have signed the IAIS Multilateral MoU before inviting their participation in the college. Before a new and/or a third country supervisor joins the college, agreement of all college members is necessary.

Involved supervisors agree on a clear allocation of tasks within the college. The sharing and delegation of tasks are based on the terms agreed upon by the supervisors, in line with the coordination arrangement. Delegation and/or sharing of tasks are to be discussed at the same time of the planning of supervisory activities in the college (i.e., via a working plan) or at the request of any of the supervisors. Currently, supervisors agree on the sharing and delegation of tasks mostly in the approval of internal models.

The effective procedures for information exchange were discussed during college meetings and recorded in the meeting minutes. For example, before the college meeting, supervisors were asked to fill in a template with local financial information (based on the template by EIOPA). The results are loaded into the collaboration tool. After the meeting, supervisors would request the insurance group to provide information to the group supervisor, to be updated into the collaboration tool.

As the group supervisor, the NBB is responsible for communication with representatives at the group level, while other supervisors may communicate with these representatives if agreed within the college and by the NBB. Any communication at the group level should be related to the group supervisor to minimize duplicate information requests. Conveyance of information may involve a multilateral meeting between the NBB, host supervisors and the senior management of the group. If the college agrees, the group may be invited to attend the college meetings to present its position regarding the issues under consideration.

The frequency and method of college meetings will be determined by the NBB, if it acts as the group supervisor. Given the crucial role of the college, it should meet face-to-face at least once a year. If appropriate, regular or ad-hoc exchange of information between college members/participants is expected, e.g., joint onsite visits and approval of internal models. The agenda of a college meeting of a large insurance group in March 2012 included discussions on the strategy, organisation and results of the group, the coordination arrangement, an emergency plan, information exchange, joint decisions to be taken, joint risk assessment and a supervisory action plan.

Solvency II requires the designation of a group supervisor. In anticipation of the implementation of Solvency II, the NBB recognised all group supervisors in a group where it is host, and other supervisors also recognised the NBB in groups where it acts as group supervisor. Such recognition is documented in the coordination arrangement of the relevant supervisory college. (Art 247 (1) of Solvency II Directive)

The NBB's role as the group supervisor in the supervisory college includes:

Chairing the college meetings and decides, after consulting the other college members, which supervisors participate in a meeting or in an activity of the college, and coordinates the meetings as well as the college's activities;

Reviewing the group structure and make necessary changes to the conduct of meetings and activities, in the event of major changes in group structure or organisation. The NBB provides the other members with an updated list of all insurers at least annually;

Informing the other members in a timely manner on: changes in the major shareholders and the Board of directors; and financial situation of the group (particularly on profitability, solvency, capital adequacy, intra-group transactions and risk concentration); 


\begin{tabular}{|c|c|}
\hline & 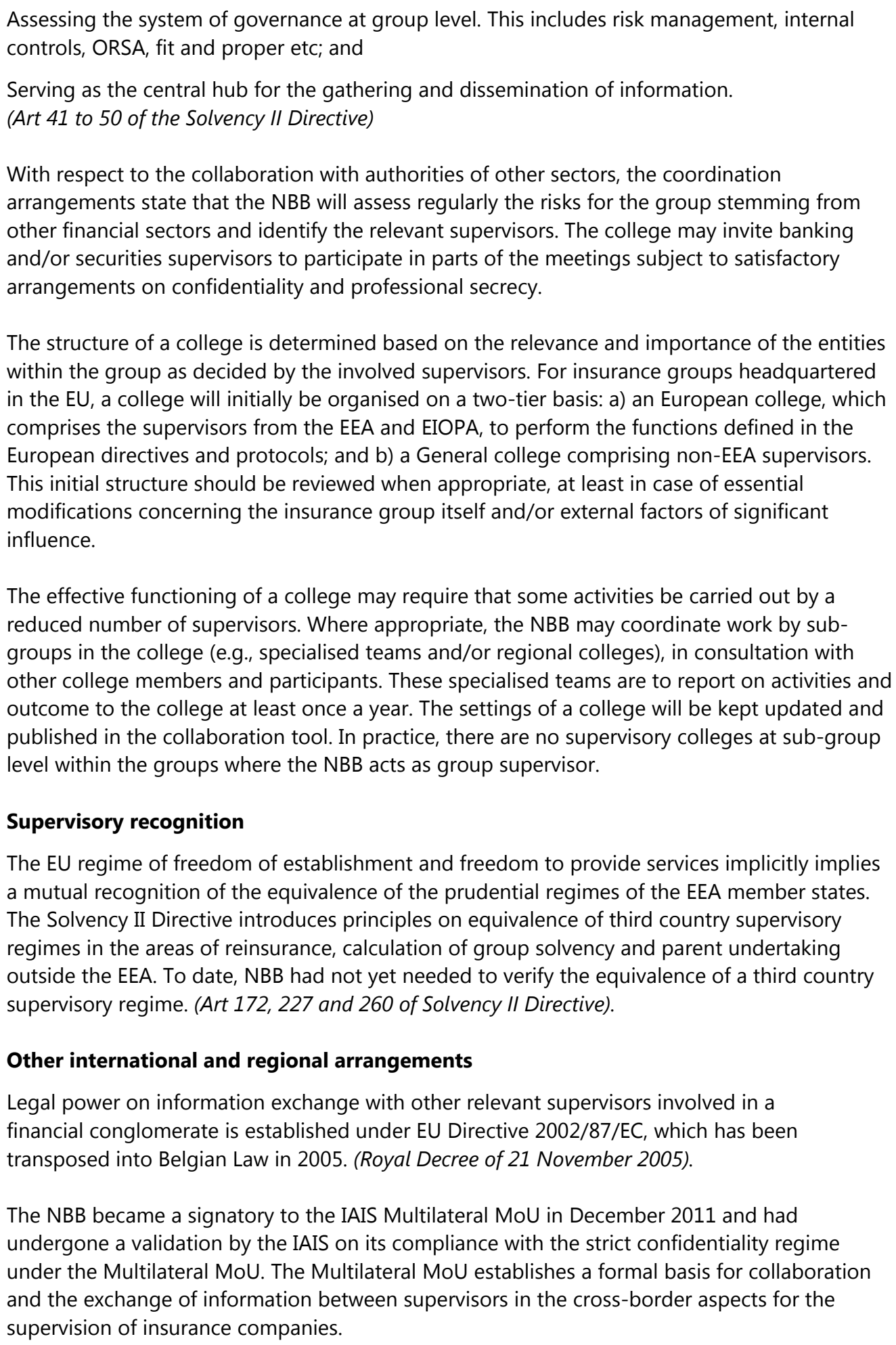 \\
\hline Assessment & Observed. \\
\hline Comments & In preparation for the implementation of Solvency II, the NBB has established comprehensive \\
\hline
\end{tabular}




\begin{tabular}{|c|c|}
\hline & $\begin{array}{l}\text { coordination arrangements with other involved supervisors to facilitate effective supervision } \\
\text { on a legal-entity and a group-wide basis. The NBB chair three supervisory colleges as the } \\
\text { group-wide supervisor, with the mandate to establish the key functions and other } \\
\text { coordination mechanisms of these colleges. Where appropriate, the NBB coordinates with } \\
\text { relevant agencies from other sectors, including central banks and government ministries. } \\
\text { Pending the implementation of Solvency II, the coordination arrangements have not been } \\
\text { concluded for all insurance groups although all the colleges have been operating in line with } \\
\text { the EIOPA's templates. The NBB became a signatory to the IAIS Multilateral MoU in December } \\
2011 \text {, facilitating cross-border cooperation with non-EEA members who are signatories to this } \\
\text { multilateral MoU. }\end{array}$ \\
\hline ICP 26 & $\begin{array}{l}\text { Cross-border Cooperation and Coordination on Crisis Management } \\
\text { The supervisor cooperates and coordinates with other relevant supervisors and authorities } \\
\text { such that a cross-border crisis involving a specific insurer can be managed effectively. }\end{array}$ \\
\hline Description & $\begin{array}{l}\text { The NBB organizes meetings of supervisory colleges as group-wide supervisor or participates } \\
\text { in such meetings, at least annually (ICP 25). The coordination agreements amongst the college } \\
\text { members contain provisions for cooperation of in crisis situations. EIOPA stipulates each year a } \\
\text { minimum list of measures to be included in the action plan of all supervisory colleges. The } \\
\text { action plan for } 2011-2012 \text { includes the establishment and approval of an emergency plan. } \\
\text { The NBB is currently establishing emergency plans for insurance groups to: facilitate the } \\
\text { sharing of confidential information on short notice within the college; secure an early crisis } \\
\text { alert for timely coordination and cooperation; promote effective and efficient communication } \\
\text { within the college and to the public. The emergency plan includes: } \\
\text { - A description of certain (including potential) events that would trigger an emergency alert; } \\
\text { - A list of information supervisors should be able to produce on short notice; } \\
\text { A high level description of crisis assessment, crisis management and external } \\
\text { communication; and } \\
\text { The different roles of the college members to provide a common understanding of the } \\
\text { division of tasks. } \\
\text { The coordination agreements of the supervisory colleges recognise that the group supervisor } \\
\text { is responsible for the coordination and exercise of supervision on a group basis, both on a } \\
\text { going concern and crisis situations. The group supervisor coordinates crisis management } \\
\text { preparations, crisis assessment and crisis management activities in close cooperation with } \\
\text { other involved supervisors. The group supervisor also regularly informs EIOPA about these } \\
\text { activities and the progress made. Any potential impediments to a coordinated solution are } \\
\text { usually discussed between college members during the drafting of the coordination } \\
\text { arrangement and the emergency plan. } \\
\text { between the members of a college, both on a routine basis and during a crisis. The } \\
\text { collaboration tool is an IT platform which provides the members with: a secured channel for }\end{array}$ \\
\hline
\end{tabular}


handling confidential information; key supervisory information on an insurance group: up-todate view of the group structure; and a contact list ${ }^{48}$ in member organisations that is regularly updated. Any crisis-management information, plans and tools are posted on this platform.

Information on the group structure provides college members with an overview to assess cross-border implications of a crisis. Potential inter-linkages between the group and the financial system are assessed in relation to the group structure, the nature and main risks of the group. During the college meetings, a risk assessment is presented by the group supervisor and discussed.

Insurance groups are required to provide the relevant information to the college as inputs to the emergency plan and the data/information shared via the collaboration tool. The preparation of a contingency plans for an insurance groups also envisage certain information needs by both the groups and the involved supervisors.

Currently, insurance groups are not legally obliged to establish crisis management plans or contingency plans. In line with the $2008 \mathrm{MoU}$ on cooperation on cross-border financial stability between the supervisory authorities, central banks and finance ministries of the EU (MoU - FS), the NBB encourages the Belgian insurance groups for which it acts as the group supervisor, to set up contingency plans. Progress has been made in some groups and the NBB has been working closely with them and other college members. EIOPA will likely require contingency plans to be included in the action plan of supervisory colleges in 2013.

The MoU-FS defines how the procedures for coordinating a cross-border crisis are activated and allocates responsibilities between the home and host supervisors. The $\mathrm{MoU}$ is operationalized through the emergency plans. The supervisor who becomes aware of an emerging financial distress or events that may give rise to significant problems will inform the group supervisor as soon as possible. The group supervisor will then inform the core college and all involved supervisors and EIOPA through the most appropriate means i.e., emails, conference calls, bilateral/multilateral meetings or via the collaboration tool.

The trigger events that call for an emergency alert include: significant deficiency in solvency margin; major violation of legal requirements; risk of failure of a material reinsurer; public investigation against an insurer (e.g., fraud); and macro-economic, financial and insurancesector developments with implications for the financial soundness of a group and its entities. The group supervisor receives and distributes confidential information via a secured infrastructure (which is tested regularly). Information sharing with involved supervisors is described in ICP 3 and ICP 25.

The emergency plan specifies that the group supervisor should assess the nature of the financial crisis and its implications in cooperation with other involved supervisors and EIOPA. The objective is to ascertain the impact of the crisis, including systemic implications, and to decide whether to intervene, and if so, how to intervene. Based on the supervisors' joint assessment, college members agree on the need, scope and conditions for any supervisory actions to be taken.

A cross-border systemic financial crisis that requires the management and resolution at the

${ }^{48}$ The Helsinki Protocol list (with the main contact persons of supervisory authorities) complements the EIOPA Members and Observers Crisis Contact list. A detailed college directory provides all contact persons relating to the supervision of the insurance group. The group supervisor updates the directories at least once a quarter. 


\begin{tabular}{|c|c|}
\hline & $\begin{array}{l}\text { ministries level and involvement of other parties may adopt different procedures, and will be } \\
\text { guided by the framework established by the MoU-FS. } \\
\text { Pursuant to an emergency plan, the group supervisor is in charge of coordinating public } \\
\text { communication at each stage of the crisis, taking into consideration the communication of the } \\
\text { insurance group to the public and exercising discretion on the scope of disclosure to maintain } \\
\text { market confidence. In exceptional circumstances, a supervisor may issue separate public } \\
\text { statements but it must inform the group supervisor as soon as possible. } \\
\text { The NBB has launched a pilot project and issued guidelines specifying the approach to be } \\
\text { adopted by SIFIs in formulating their recovery plans. } \\
\text { During the period } 2008 \text { to } 2011 \text {, the Belgian authorities took decisive intervention measures } \\
\text { including recapitalisation and state guarantee, which helped stabilized the financial system. } \\
\text { However, they were confronted with some challenges e.g., the lack of a proper legal basis for } \\
\text { the resolution of financial institutions. The Law of June } 2,2010 \text { removed some of these } \\
\text { obstacles. The deposit insurance scheme was extended to cover life insurance contracts in } \\
2008 \text { on a voluntary basis and became mandatory for policies that offer guaranteed returns } \\
\text { and the coverage was increased to } € 100 \text { 000. } \\
\text { In the event of a sudden financial crisis or a serious threat of a systemic crisis, the King, upon } \\
\text { the recommendation of the NBB, may inter alia: a) determine regulations supplementing or } \\
\text { derogating from the Insurance Law and the Supervision Law; b) granting a State guarantee for } \\
\text { commitments of insurers; and c) granting State cover for losses incurred by asset management } \\
\text { companies. These measures may cover insurers as well as their direct and indirect subsidiaries } \\
\text { (Art } 36 / 24, N B B \text { Organic Law). }\end{array}$ \\
\hline Assessment & Largely observed. \\
\hline Comments & $\begin{array}{l}\text { The Belgian regime for cross-border cooperation and coordination on crisis management is } \\
\text { based on the EU framework, which has been partially operationalized. The EU Framework } \\
\text { supports and provides guidance on coordinating the arrangements for crisis preparation, } \\
\text { management and resolution by supervisory colleges in EU. However, coordination } \\
\text { arrangements and emergency plans have not yet been implemented for all supervisory } \\
\text { colleges that the NBB participates in. Some insurance groups are still in the process of } \\
\text { developing their contingency plans. } \\
\text { The conclusion of the coordination arrangements and emergency plans will enable the NBB to } \\
\text { implement cross-border cooperation and coordination on crisis management for insurance } \\
\text { groups. The arrangements and plans should also be regularly tested by all involved supervisors } \\
\text { to ensure their operational effectiveness and to detect any gaps in procedures or information. } \\
\text { In addition, the authorities is advised to consider empowering the NBB to require insurers and } \\
\text { insurance to establish crisis management plans or contingency plans for use in a going- and } \\
\text { gone-concern situation. }\end{array}$ \\
\hline
\end{tabular}

